\title{
Title:
}

\section{Ancient genomes from Iceland reveal the making of a human population}

\section{One Sentence Summary:}

Ancient genomes from Iceland provide unique insights into the making of a human population shaped by extensive genetic drift.

\section{Authors:}

S. Sunna Ebenesersdóttir ${ }^{1,2}$, Marcela Sandoval-Velasco ${ }^{3}$, Ellen D. Gunnarsdóttir ${ }^{1,2}$, Anuradha Jagadeesan $^{1,2}$, Valdís B. Guðmundsdóttir ${ }^{1,2}$, Elísabet L. Thordardóttir ${ }^{1,2}$, Margrét S. Einarsdóttir $^{1,2}$, Kristján H. S. Moore ${ }^{1}$, Ásgeir Sigurðsson ${ }^{1}$, Droplaug N. Magnúsdóttir ${ }^{1}$, Hákon Jónsson ${ }^{1}$, Steinunn Snorradóttir ${ }^{1}$, Eivind Hovig ${ }^{4,5,6}$, Pål Møller ${ }^{4,7,8}$, Ingrid Kockum ${ }^{9}$, Tomas Olsson $^{9}$, Lars Alfredsson ${ }^{10}$, Thomas F. Hansen ${ }^{11,12}$, Thomas Werge ${ }^{11,13,14}$, Gianpiero L. Cavalleri $^{15}$, Edmund Gilbert ${ }^{15}$, Carles Lalueza-Fox ${ }^{16}$, Joe W. Walser III $^{17,18}$, Steinunn Kristjánsdóttir ${ }^{17,18}$, Shyam Gopalakrishnan ${ }^{3}$, Lilja Árnadóttir ${ }^{17}$, Ólafur P. Magnússon ${ }^{1}$, M. Thomas P. Gilbert ${ }^{3}$, Kári Stefánsson ${ }^{1,19}$ and Agnar Helgason ${ }^{1,2}$

\footnotetext{
Affiliations:

${ }^{1}$ deCODE Genetics/AMGEN, Inc., Reykjavik Iceland.

${ }^{2}$ Department of Anthropology, University of Iceland, Reykjavik, Iceland.

${ }^{3}$ Natural History Museum of Denmark, University of Copenhagen, Øster Voldgade 5-7, 1350 Copenhagen K, Denmark.

${ }^{4}$ Department of Tumor Biology, Institute for Cancer Research, Oslo University Hospital, Oslo, Norway.

${ }^{5}$ Institute for Cancer Genetics and Informatics, Oslo University Hospital, Oslo, Norway.

${ }^{6}$ Department of Informatics, University of Oslo, Oslo, Norway.

${ }^{7}$ Department of Human Medicine, Universität Witten/Herdecke, Witten, Germany.

${ }^{8}$ Research Group Inherited Cancer, Department of Medical Genetics, Oslo University Hospital, Oslo, Norway.

${ }^{9}$ Center for Molecular Medicine, Department of Clinical Neuroscience, Neuroimmunology Unit, Karolinska Institutet, Stockholm, Sweden.

${ }^{10}$ Institute of Environmental Medicine, Karolinska Institutet, Stockholm, Sweden.

${ }^{11}$ Institute of Biological Psychiatry, Copenhagen Mental Health Services, Copenhagen, Denmark.

${ }^{12}$ Danish Headache Center, Dept. of Neurology, Copenhagen University hospital, DK-2600 Glostrup, Denmark.

${ }^{13}$ Department of Clinical Medicine, University of Copenhagen, Copenhagen, Denmark.

${ }^{14}$ The Lundbeck Foundation Initiative for Integrative Psychiatric Research, iPSYCH, Copenhagen, Denmark.

${ }^{15}$ Molecular and Cellular Therapeutics, Royal College of Surgeons in Ireland, 123 St. Stephen's Green, Dublin, Ireland.

${ }^{16}$ Institut de Biologia Evolutiva, (UPF-CSIC), Barcelona, Spain.

${ }^{17}$ National Museum of Iceland, Reykjavik, Iceland.

${ }^{18}$ Department of Archaeology, University of Iceland, Reykjavik, Iceland.

${ }^{19}$ Norwegian University of Science and Techonology, University Museum, 7491 Trondheim, Norway

${ }^{20}$ Faculity of Medicine, University of Iceland, Reykjavik, Iceland.
} 


\begin{abstract}
:
Opportunities to directly study the founding of a human population and its subsequent evolutionary history are rare. Using ancient genomes from 27 skeletal remains, we demonstrate that the earliest Icelanders were a combination of Norse, Celtic and admixed individuals. We further show that ancient Icelanders are much more similar to their source populations in Scandinavia and the British Isles and Ireland than to contemporary Icelanders, who have been shaped by 1100 years of extensive genetic drift. Finally, we report evidence for unequal contributions from the ancient founders to the contemporary Icelandic gene pool, which was in part influenced by ancestry. These results provide unique insights into the making of a human population that has proven extraordinarily useful for the discovery of genotype-phenotype associations.
\end{abstract}

\title{
Main text:
}

Historical sources (1) indicate that Iceland was settled by people from Norway and the British Isles (defined here as the United Kingdom and Ireland) between 870-930 A.D. (2, 3). Throughout the preceding century, the Norse had raided, traded and settled in the islands and coastal regions of Ireland, Scotland and northern England (4). The number of settlers in Iceland is thought to have been in the range of $8,000-16,000$, with the population rarely exceeded 50,000 until 1850 (3), after which there was a rapid expansion to its current size of 330,000.

Previous studies of mitochondrial DNA (mtDNA) and Y chromosomes from contemporary Icelanders indicate that while $62 \%$ of their matrilineal ancestry stems from Scotland and Ireland, $75 \%$ of their patrilineal ancestry is Scandinavian (5-7). Moreover, mtDNA control region sequences from 68 Icelandic ancient skeletal remains $(\sim 1,000$ years old) were reported to be more similar to those observed in the contemporary source populations in Scandinavia 
and the British Isles than those in contemporary Icelanders (8). This was explained by loss of mtDNA haplotypes from the Icelandic gene pool due to extensive genetic drift (8), an interpretation that is supported by founder events revealed through whole genome sequencing (WGS), genome-wide association studies (9) and population genetics analyses (10). Here, we use WGS data from the earliest generations of Icelanders to directly assess the formation and subsequent evolution of a human population.

We selected 35 skeletal remains from 27 geographically dispersed sites within Iceland for sequencing (Fig. 1). Based on archaeological context (typically grave artifacts) $(11,12)$ or radiocarbon dating $(13,14), 31$ of the remains are deemed to have been from pre-Christian burials (<1000 A.D.), one from an early Christian burial before 1104 A.D. (PSK-A26), two with unknown dates (TGS-A1 and FOV-A1), and one (KOV-A2) born in 1678 (Table S1). Following established ancient DNA (aDNA) protocols (SM S2), 61 double-stranded DNA libraries were produced from 50 different DNA extracts, and Whole Genome Enrichment (WGE) (15) was used to enrich for human DNA fragments before sequencing. The libraries were assessed for pre-capture DNA concentration, the proportion of post-capture human mapped reads (endogenous content), contamination, and genome coverage, which led to the exclusion of eight individuals from pre-Christian burials from subsequent analyses (Fig. 1 and Table S2).

For the 27 individuals who passed quality control criteria, the average number of reads per position in the human autosomal reference genome obtained ranged from 0.18 to 30.7 , with a median of 0.71 (Table 1). The authenticity of the mapped reads is supported by several different analyses (SM S2). First, all libraries yielded short read lengths (Table S3) and patterns of cytosine deamination that were consistent with aDNA (16) (Figs. S1 and S2). Second, contamination levels were negligible $(<1.9 \%)$ (Table S4). Third, mtDNA consensus sequences for all 27 ancient individuals matched those obtained from a previous study (8) (Table S5). 
Using $R_{y}$, the proportion of sex chromosome reads that mapped to the Y chromosome (17), it was possible to confidently assign sex to 26 of the individuals (Fig. S3A and Table S6). The result for one individual, YGS-B2, was ambiguous, as $R_{y}=0.055$ was much greater than the upper limit for females (0.016) and well below the lower limit for males (0.077). An examination of read depth on the sex chromosomes relative to the autosomes indicates that YGS-B2, who died before adulthood, carried two X chromosomes and one Y chromosome (Fig. S3B). To our knowledge, this is the first report of an individual with Klinefelter syndrome or any kind of aneuploidy based on aDNA. Of the 23 individuals from pre-Christian burials, 18 $(78 \%)$ were male $\left(X^{2}\right.$ test against expectation of $\left.50 \%, \mathrm{P}=0.012\right)$. As the individuals were not selected on the basis of morphologically predicted sex, it is likely that there were sex differences in burial practices during this period (18), such that female burials were either rarer or less likely to be identified and reported to the National Museum of Iceland as pre-Christian.

We next sought to establish the relationship between the ancient Icelanders and contemporary population samples genotyped on micro-array SNP chips (Table S7). As the read depth for most of the ancient Icelanders was too low to call diploid genotypes, haploid genotypes were used in all analyses (obtained by randomly sampling one allele from high quality reads). Based on previous genetic studies $(5-8,10,19,20)$, and historical, archaeological and linguistic evidence $(2,12,21)$, the ancient Icelanders are expected to be most closely related to the contemporary populations from Iceland, Scandinavia and the British Isles. To validate this expectation, we performed a principal components analysis (PCA) based on 2,139 contemporary individuals from 28 European populations, using genotypes from 227,056 SNPs. When projected onto the first two principal components (PCs), all the ancient Icelanders are placed clearly within the clusters of contemporary individuals from Scandinavia and the British Isles (Fig. S4). 
For a more detailed assessment of the relationships between the ancient Icelanders and their source populations, we performed a PCA based on genotypes from contemporary individuals from Scandinavia $(n=3,118)$, the British Isles $(n=1,436)$ and Iceland $(n=916)$, using diploid genotypes from 404,066 autosomal SNPs. Figure 2A shows a clear separation of contemporary individuals from Scandinavia and the British Isles on PC2, reflecting allele frequency differences that have accumulated through several thousand years of drift, added to possible differences in contributions from the ancestral source populations of Europe (22-25). PC1 reveals an even more marked separation of contemporary Icelanders from their source populations. The average genetic distance $\left(\mathrm{F}_{\mathrm{ST}}\right)(26)$ between Icelanders and the other populations in Fig. 2A is 0.00208 , whereas comparable distances for the source populations range from a minimum of 0.00092 for England to a maximum of 0.00174 for Wales (Fig. S5).

The most likely cause for the divergence of Icelanders is 1100 years of genetic drift resulting from an initial founder event and subsequent small population size (8-10). This interpretation is supported by the PCA projection of the one early Christian and 23 pre-Christian ancient Icelanders, all of whom are placed on the plane of PC1 occupied by contemporary individuals from Scandinavia and the British Isles in Fig. 2A (see also Figs. S6 and S7). This also implies that the gene pools of these source populations have changed much less during the same period (8). Further support is provided by PCA projections of ancient individuals $(n=16)$ from the British Isles dating from the Neolithic to the Anglo-Saxon period (22, 27, 28) (SM S4 and Table S8), who plot among contemporary British and Irish populations (Fig. S8). This justifies the use of contemporary individuals from these source populations as reasonable proxies for ancient inhabitants at the time Iceland was settled.

The PC2 axis in Fig. 2A provides information about the mixed ancestry of the ancient Icelanders (5-8). Thus, while some appear to be fully Scandinavian or British/Irish, others resemble a mixture of these ancestral groups. For a more explicit evaluation of ancestry of the 
ancient Icelanders, contemporary genotyped individuals were grouped into Norse $(n=2,139)$ (Norway and Sweden), Celtic $(n=459)$ (defined here as Ireland and Scotland, excluding Orkney) and Icelandic reference populations. Fig. 2B shows the relationship between the ancient individuals and these two reference populations using D-statistics (29) in the form D(Yoruba, X; Norse, Celtic) (Table S9). To directly estimate the ancestry of the ancient Icelanders, we used ADMIXTURE in supervised mode with the Norse and Celtic reference populations $(\mathrm{K}=2)$ (Fig. 2C). The results were consistent with those obtained from the placement of the ancient Icelanders on the PC2 axis in the PCA in Fig. 2A and D-statistics in Fig. 2B (Pearson's $|r|>0.98$ between all three assessments of ancestry).

An assessment of $\mathrm{Y}$ chromosome variants among the 22 ancient Icelandic males revealed that all belonged to the haplogroups I1, R1a and R1b1 (Table 1). As I1 and R1a are common in Norse and R1b1 in Celts $(7,30,31)$ (Table S10), we postulated and confirmed that there was a corresponding association between $\mathrm{Y}$ chromosome haplogroups and autosomal Norse/Celtic ancestry (Fig. 2C) in the 18 pre-Christian Icelanders (ANOVA p=0.02).

We estimated the mean Norse ancestry of the settlement population (23 pre-Christians and one early Christian) to be 0.554 (95\% C.I. 0.308-0.692), with a small non-significant difference between the sexes (0.563 in males and 0.521 in females). When the same ADMIXTURE analysis was applied to the 916 contemporary Icelanders, we obtained a mean Norse ancestry of 0.704 (95\% C.I. 0.699-0.709). This suggests that reproductive success among the first generations of Icelanders was stratified by ancestry, as genetic drift alone is unlikely to systematically alter ancestry at thousands of independent loci. This is perhaps not surprising, as many of the individuals of Celtic ancestry are thought to have been brought to Iceland as slaves, whose survival and freedom to reproduce is likely to have been under constraint (21).

Of the 23 pre-Christian Icelanders in our study, 20 have been tested for strontium isotopes 86 and 87 in their dental enamel, which can be used to determine whether they spent 
the first six years of their lives in Iceland (non-migrants) or elsewhere (migrants) $(14,32)$. Three are certain to have been migrants based on high ${ }^{87} \mathrm{Sr} /{ }^{86} \mathrm{Sr}$ ratios $(>0.710)$, and most probably, first generation settlers (Table 1). All three were unmixed according to our results; DAV-A8 and DAV-A9 (from the same burial site) were fully Norse, and SSG-A4 was a Celt (Fig. 2C). Two further individuals (SSG-A2 and SSG-A3, both from the same burial site as SSG-A4) have ${ }^{87} \mathrm{Sr} /{ }^{86} \mathrm{Sr}$ values that are considerably lower, but still too high for a childhood spent only in Iceland. Interestingly, the ancestry of SSG-A3 is estimated to have been a nearly even mix of Norse and Celtic, which indicates that at least some admixture occurred before arrival to Iceland, perhaps in Viking settlements in Scotland or Ireland. Of the 15 pre-Christians with ${ }^{87} \mathrm{Sr} /{ }^{86} \mathrm{Sr}$ values consistent with non-migrants, four were effectively unmixed (>90\%) Norse (SVK-A1, NNM-A1, DKS-A1 and SSJ-A2) and two were unmixed Celts (ORE-A1 and KNSA1) (Fig. 2C). This suggests that some segregation was maintained between Norse and Celtic individuals in Iceland, at least during the early generations of Icelanders.

An intriguing implication of the extensive drift that has accumulated in the Icelandic gene pool is that skeletal remains from Iceland could be dated based on the proportion of drift shared with the contemporary population. To test this, we sequenced the genome of an Icelander born in 1678 (KOV-A2), projected his genotypes onto the PCA in Fig. 2A and found that he was placed roughly halfway between the clusters of contemporary Icelanders and their source populations. This is consistent with KOV-A2's genome being shaped by only part of the drift that characterizes contemporary Icelanders. Following on from this observation, we projected genotypes from the remains of two Icelanders with uncertain temporal origin (TGS-A1 and FOV-A1). Based on their positions on the PC1 axis, we infer that TGS-A1 dates from the first generations after the settlement of Iceland, as he plots among other pre-Christian individuals. In contrast, FOV-A1 may have been born some centuries later, as he plots outside the range of pre-Christian individuals and closer to KOV-A2 and the contemporary Icelanders. 
Further insights into the temporal origin of TGS-A1 and FOV-A1 can be gained through an analysis of drift shared with the Norse, Celtic and Icelandic reference populations. Fig. 3A shows a scatterplot of two D-statistics: D(YRI, X; Norse, Iceland $)$ and $D(Y R I, X ;$ Celts, Iceland $)$ for all 27 ancient Icelanders (Table S11), which effectively distinguishes the signature of Iceland-specific drift (an axis that is parallel to the diagonal line) from that of Norse-Celtic ancestry (perpendicular deviation from that line). Consistent with the PCA plot in Fig. 2A, preChristian Icelanders plot very close to contemporary Norse and Celts. Furthermore, KOV-A2 is closer to contemporary Icelanders, whereas FOV-A1 plots roughly halfway between them and the contemporary Celtic and Norse source populations. TGS-A1, the second sample of unknown temporal origin, clusters with a group of four pre-Christian Icelanders (VDP-A5, DAV-A9, NNM-A1 and SVK-A1) who fall just outside the space occupied by contemporary Norse (a similar trend is observed in PC1 axis in Fig. 2A).

The greater genetic drift these individuals share with contemporary Icelanders is intriguing and is also apparent in the results of ADMIXTURE, run in supervised mode with three contemporary reference populations $(\mathrm{K}=3)$ : Norse, Celtic and Icelandic (Fig. 3B, the correlation between the proportion of Icelandic ancestry and PC1 in Fig. A2 is $|r|=0.913$ ). However, the evidence that they belonged to the first generations of Icelanders is strong; namely, pre-Christian burials features, early ${ }^{14} \mathrm{C}$ dates (DAV-A9 and SVK-A1), strontium isotopes consistent with being raised outside of Iceland (DAV-A9) (Table 1), and the finding that three have unmixed Norse ancestry (DAV-A9, NNM-A1 and SVK-A1, Fig. 2C). Thus, temporal misclassification is doubtful. Another possible explanation is contamination from contemporary Icelanders, but contamination is estimated to be negligible in all four individuals (Table S4). We postulate that three different factors could account for the greater shared drift of the four pre-Christian Icelanders and TGS-A1 with contemporary Icelanders. First, subtle genetic drift affecting the Norse gene pools during the past 1100 years might have shifted allele 
frequencies so as to make contemporary Norse less representative of their ancestors than is the case for the Celts. Second, these ancient Icelanders might have originated from a sub-population within Scandinavia that is not well represented in our reference samples. Third, it is possible that these ancient individuals contributed disproportionately to the gene pool of contemporary Icelanders. We reasoned that if genetic drift or population sub-structure in Scandinavian populations were responsible for the outlying position of VDP-A5, DAV-A9, NNM-A1 and SVK-A1 in Figs. 2A and 4A, then they would also be outliers in a PCA generated based only on the contemporary individuals from Scandinavia and the British Isles. As shown in Fig. 3C, these ancient Icelanders fall well within the cluster of contemporary Scandinavians. Thus, it may be concluded that these individuals contributed more to the contemporary Icelandic gene pool than other pre-Christian Icelanders in our study and that TGS-A1 may also fall into this category. We note that this observation is consistent with our inference that settlers of Norse ancestry had greater reproductive success than those of Celtic ancestry.

Ancient genomes are key to answering many important questions about the formation and evolution of human populations during recent millennia. The settlement of Iceland occurred around 1100 years ago at the height of the Viking age. Our study of ancient Icelanders reveals a highly admixed Norse and Celtic gene pool of this founding population. In addition to finding evidence for differential reproductive success by ancestry, we show that the Icelandic gene pool has been shaped by substantial genetic drift. The resultant founder events are one reason why this population has proven useful for the discovery of genotype-phenotype associations for rare sequence variants (9). 
Table 1. Summary of genomic sequence data from ancient Icelanders.

\begin{tabular}{|c|c|c|c|c|c|c|c|c|c|c|c|c|}
\hline $\begin{array}{l}\text { Time } \\
\text { period }\end{array}$ & $\begin{array}{l}\text { Classificatio } \\
\mathrm{n} \text { based on } \\
{ }^{87} \mathrm{Sr} /{ }^{86} \mathrm{Sr} \\
\text { values }\end{array}$ & Sample & $\begin{array}{r}\text { Archaeo- } \\
\text { logical } \\
\text { date }\end{array}$ & $\mathrm{C}^{14}$ date & $\begin{array}{r}\text { Auto. } \\
\text { genome } \\
\text { depth of } \\
\text { coverage }[\mathrm{X}]\end{array}$ & $\begin{array}{r}\text { Auto. } \\
\text { genome } \\
\text { covered } \\
{[\%]}\end{array}$ & $\begin{array}{r}\text { SNP } \\
\text { overlap w. } \\
\text { European } \\
\text { ref. [\%]† }\end{array}$ & $\begin{array}{r}\text { SNP overlap } \\
\text { w. North } \\
\text { European } \\
\text { ref. [\%] } \ddagger\end{array}$ & $\begin{array}{l}\text { Sex } \\
\text { chr. } \\
\text { karyo- } \\
\text { type }\end{array}$ & $\begin{array}{l}\text { mtDNA } \\
\text { haplo- } \\
\text { group }\end{array}$ & chrY haplogroup & $\begin{array}{r}{ }^{87} \mathrm{Sr} /{ }^{86} \mathrm{Sr} \\
\text { ratio }\end{array}$ \\
\hline \multirow{23}{*}{$\begin{array}{l}\text { Pre- } \\
\text { Christian }\end{array}$} & Migrant & DAV-A8 & $<1000$ & $<1050$ & 3.31 & 89.12 & 90.14 & 93.92 & $X X$ & $\mathrm{H} 1$ & NA & 0.7121 \\
\hline & & DAV-A9 & $<1000$ & $980-1020$ & 0.43 & 26.66 & 21.79 & 22.66 & $X Y$ & $\mathrm{H} 1$ & 11 & 0.7118 \\
\hline & & SSG-A2* & $<1000$ & NA & 10.56 & 94.96 & 95.58 & 99.8 & $X Y$ & $\mathrm{~J} 1 \mathrm{c} 3 \mathrm{~g}$ & R1b1a1a2a1a2c1 & 0.7095 \\
\hline & & SSG-A3* & $<1000$ & NA & 0.26 & 16.37 & 8.16 & 8.56 & $X Y$ & $\mathrm{~T} 2 \mathrm{~b} 2 \mathrm{~b}$ & 11 & 0.7093 \\
\hline & & SSG-A4* & $<1000$ & NA & 7.26 & 94.08 & 94.92 & 99.08 & $X X$ & J1b1a1a & NA & 0.7117 \\
\hline & Non-migrant & DKS-A1 & $<1000$ & NA & 0.56 & 36.43 & 28.38 & 29.59 & $X Y$ & U5a1h & R1a1a1b1a3 & 0.7088 \\
\hline & & GRS-A1 & $<1000$ & $<1050$ & 0.55 & 34.77 & 27.86 & 29 & $X Y$ & K1a1b1b & R1a1a1b1a3b & 0.7071 \\
\hline & & GTE-A1 & $<1000$ & NA & 0.25 & 13.54 & 12.73 & 13.18 & $X Y$ & $\mathrm{H} 4 \mathrm{a} 1 \mathrm{a} 4 \mathrm{~b}$ & R1a1a1b1a3a1 & 0.7061 \\
\hline & & HSJ-A1 & $<1000$ & NA & 30.74 & 96.29 & 95.73 & 99.99 & $X Y$ & $\mathrm{H} 3 \mathrm{~g} 1$ & $\mid 1 a 1 b 3 b$ & 0.7074 \\
\hline & & KNS-A1 & $<1000$ & NA & 0.71 & 43.95 & 36.2 & 37.8 & $X Y$ & H5 & R1b1a1a2a1a2c & 0.706 \\
\hline & & MKR-A1 & $<1000$ & $<1050$ & 0.18 & 11.33 & 11.25 & 11.68 & $X Y$ & $\mathrm{~K} 1 \mathrm{c} 1 \mathrm{~b}$ & R1a1a1b & 0.7065 \\
\hline & & NNM-A1 & $<1000$ & NA & 0.48 & 32.83 & 22.23 & 23.3 & $X Y$ & H2a2b5a & R1a1a1b1a3a & 0.7062 \\
\hline & & ORE-A1 & $<1000$ & NA & 0.44 & 26.26 & 22.88 & 23.79 & $X Y$ & K1a3a & R1b1a1a2a1a2 & 0.7087 \\
\hline & & SBT-A1 & $<1000$ & NA & 6.01 & 93.72 & 94.36 & 98.46 & $X Y$ & $\mathrm{H} 3 g 1 \mathrm{a}$ & I1a2a1a2 & 0.7084 \\
\hline & & SSJ-A2 & $<1000$ & NA & 0.36 & 22.41 & 14.04 & 14.77 & $X Y$ & U5a1a1 & I1a1b3 & 0.7077 \\
\hline & & STT-A2 & $<1000$ & $975-1015$ & 12.92 & 95.62 & 95.67 & 99.9 & $X Y$ & U4b1b1 & R1b1a1a2a1a2c1 & 0.7069 \\
\hline & & SVK-A1 & $<1000$ & $<1050$ & 1.07 & 67.81 & 60.95 & 63.47 & $X Y$ & 12 & 11 & 0.7078 \\
\hline & & VDP-A5 & $<1000$ & NA & 1.32 & 81.88 & 83.64 & 87.05 & $X X$ & $\mathrm{H} 3$ & NA & 0.7085 \\
\hline & & VDP-A6 & $<1000$ & NA & 1.86 & 85.92 & 63.06 & 65.83 & $X Y$ & $\mathrm{H} 1 \mathrm{c} 3 \mathrm{a}$ & R1a1a1b1a3a & 0.7089 \\
\hline & & VDP-A7 & $<1000$ & NA & 0.83 & 70.07 & 83.15 & 86.68 & $X Y$ & H4a1a1 & R1b1a1a2a1a1b & 0.7085 \\
\hline & Not available & FSS-A1 & $<1000$ & NA & 0.94 & 58.92 & 56.28 & 58.54 & $X X$ & U4a2 & NA & NA \\
\hline & & NPR-A2 & $<1000$ & NA & 0.49 & 31.88 & 31.79 & 32.93 & $X X$ & $\mathrm{~K} 1 \mathrm{a} 2 \mathrm{a}$ & NA & NA \\
\hline & & YGS-B2 & $<1000$ & NA & 0.27 & 18.37 & 14.99 & 15.67 & $X X Y$ & $\mathrm{~J} 1 \mathrm{c} 1 \mathrm{a}$ & R1b1a1a2a1a & NA \\
\hline $\begin{array}{l}\text { Early } \\
\text { Christian }\end{array}$ & Non-migrant & PSK-A26 & $\begin{array}{r}1000- \\
1104\end{array}$ & 1120 & 0.77 & 48.41 & 44.69 & 46.45 & $X Y$ & J1b1a1a & R1a1 & 0.7061 \\
\hline
\end{tabular}


$\dagger \mathrm{N}=227,056$ SNPs. $\ddagger \mathrm{N}=404,066$ SNPs. Samples marked with an asterisk symbol $(*)$ were excavated from the same site as a sample that have been subjected to carbon dating, yielding the date estimate $980-1020$ A.D 
Fig. 1.

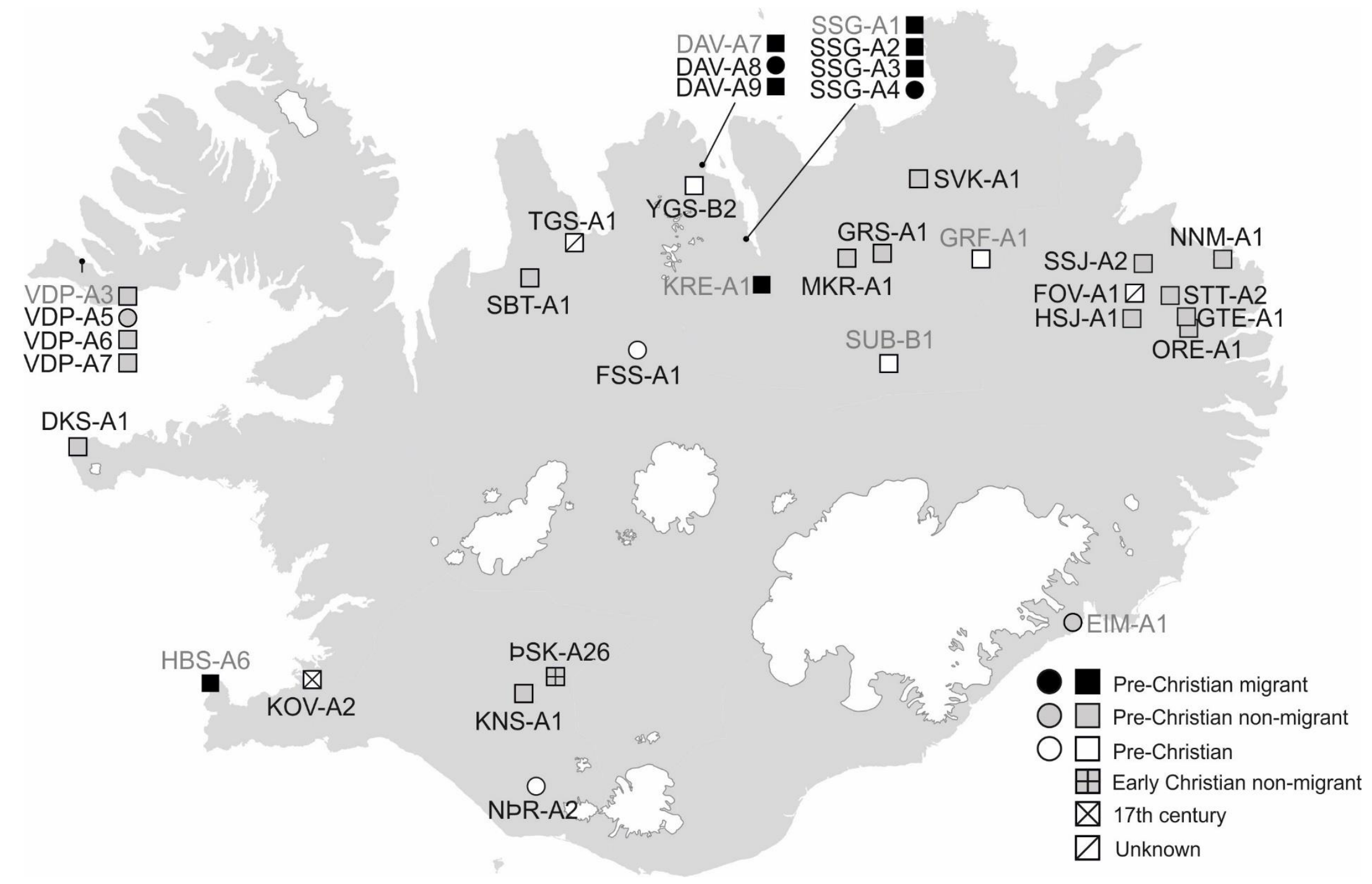


Fig. 1. A map of Iceland showing the location of excavation sites of skeletal remains sampled for this study. The first three letters in the sample ID are an abbreviation of the site (SM S1). Circles indicate females and squares males. Eight samples (light grey labels) were ultimately excluded from further analysis. 
Fig. 2.

A

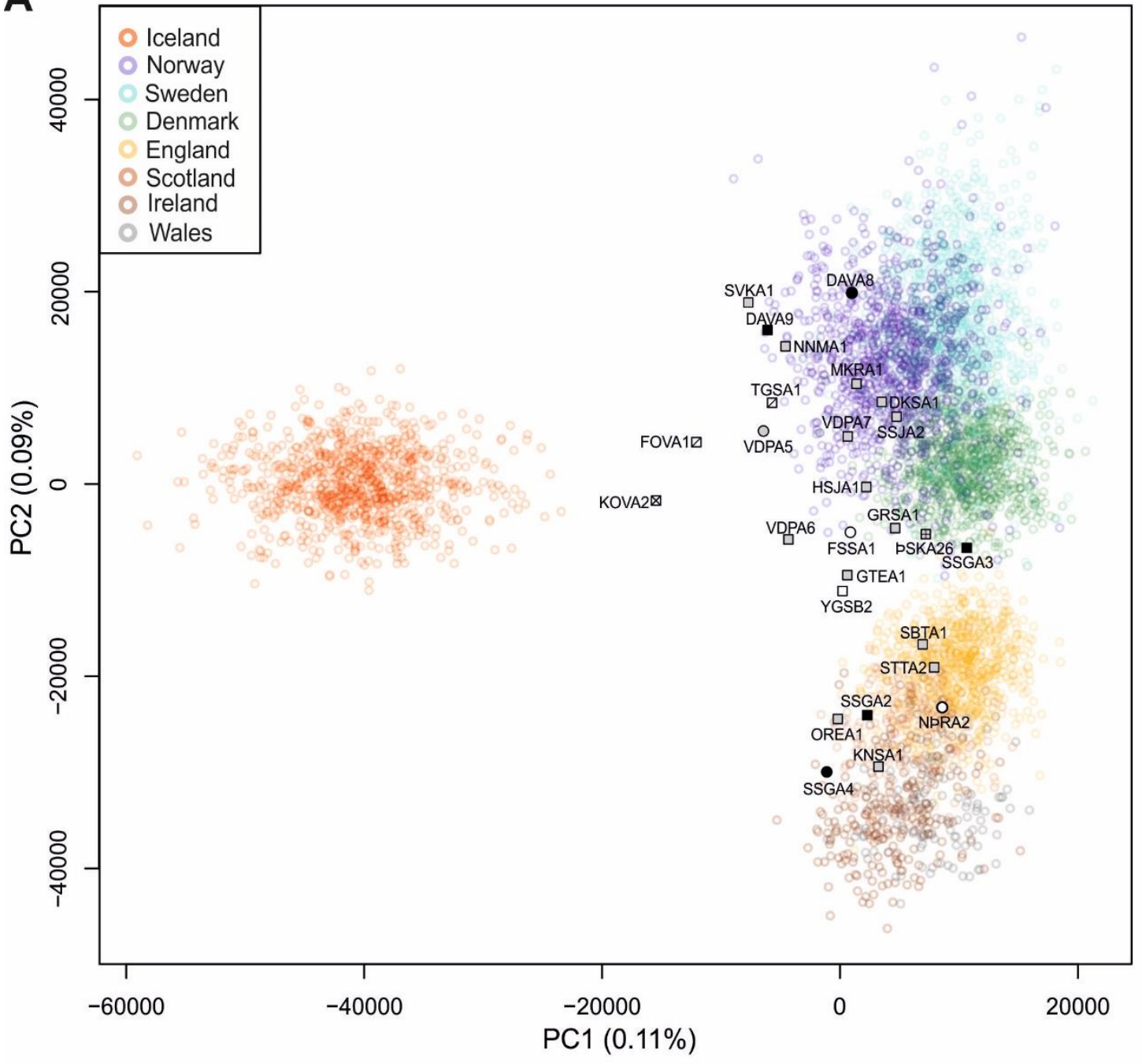

B

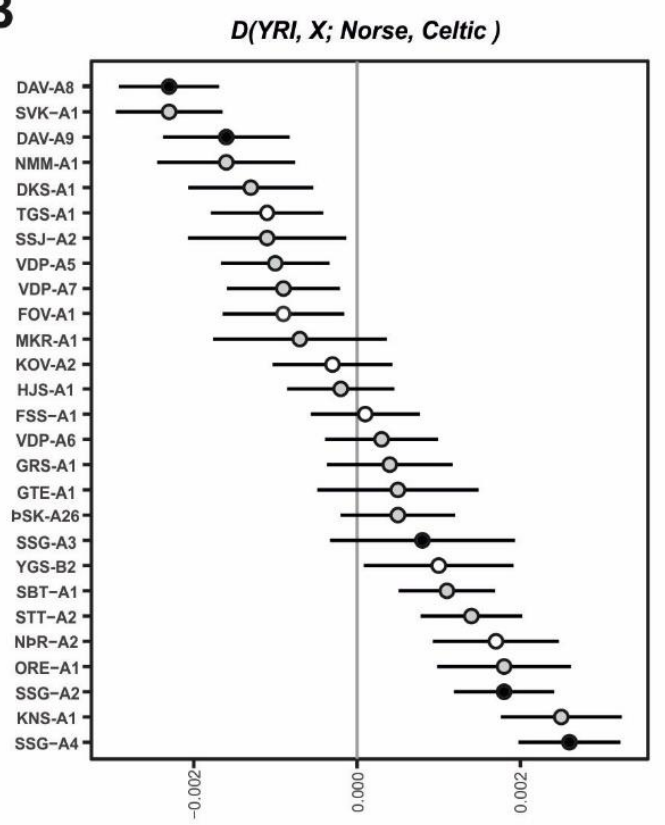

C

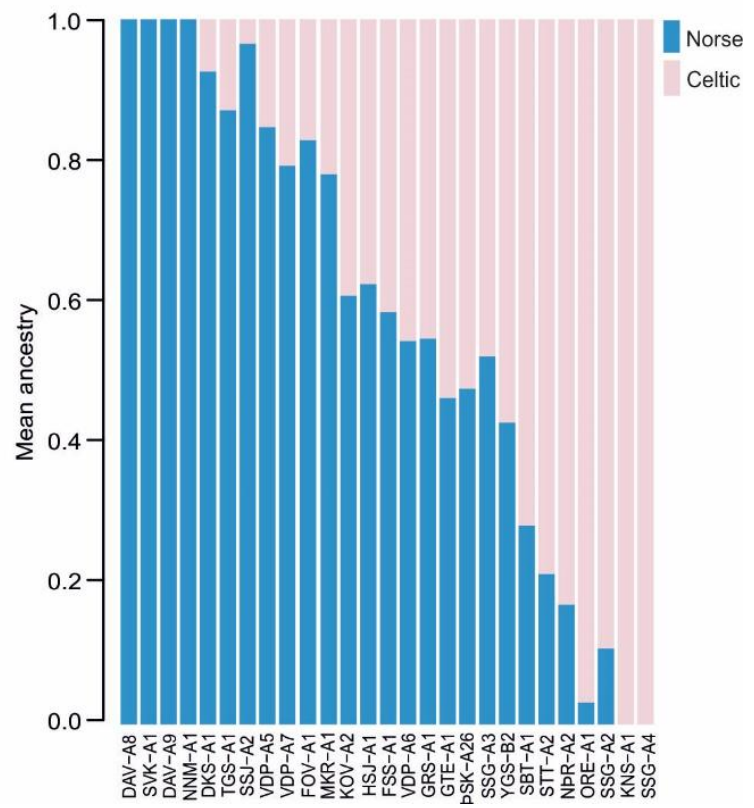


Fig. 2. Ancestry of ancient Icelanders. (A) The ancient Icelanders projected onto the first two eigenvectors of a PCA based on contemporary individuals from Scandinavia, the British Isles and Iceland. Variance explained by the first two components are shown in brackets. Symbols for ancient individuals are as specified in Fig. 1. (B) Plot of D-statistics reflecting the differential affinity of ancient Icelanders $(X)$ to Norse and Celtic reference populations, using the Yoruba from Nigeria (YRI) as an outgroup $(n=91)$. Negative values indicate more Norse ancestry and positive values indicate more Celtic ancestry, whereas values close to zero indicate mixed ancestry (as the contemporary Norse and Celts are the two best candidate source populations for Icelanders). Symbols are black for migrants, grey for non-migrants, and white where no ${ }^{87} \mathrm{Sr} /{ }^{86} \mathrm{Sr}$ values were available. (C) Estimated Norse and Celtic admixture proportions for the ancient Icelanders using ADMIXTURE in supervised mode with $\mathrm{K}=2$. 
Fig. 3.
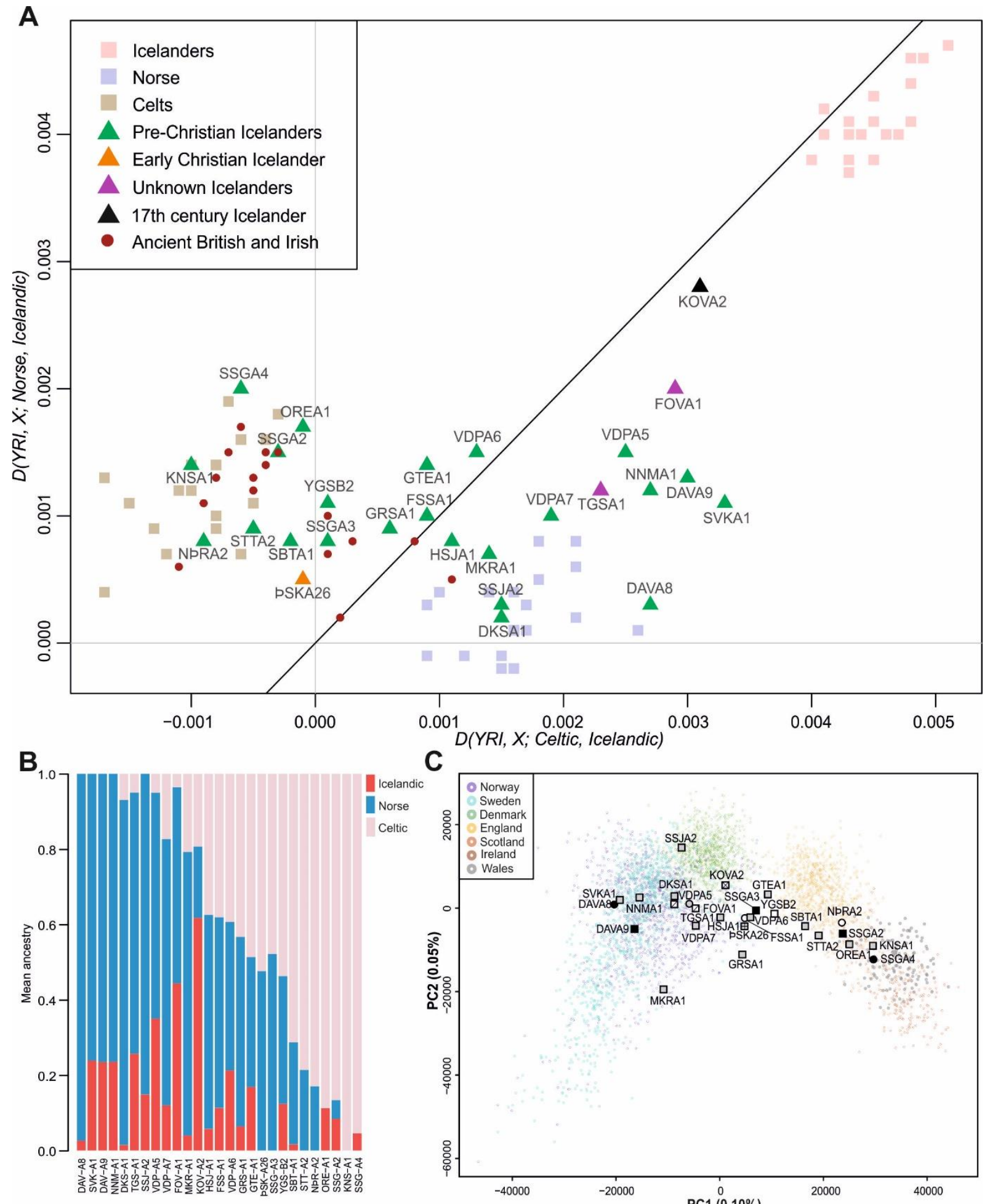

C

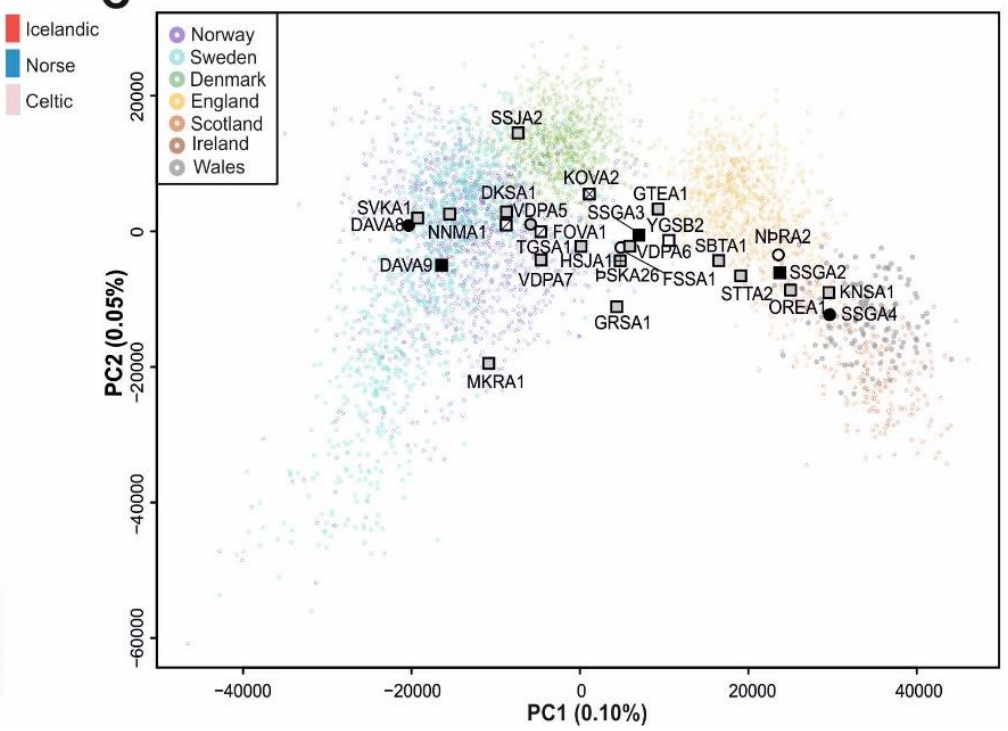


Fig. 3. Shared drift of ancient and contemporary Icelanders (A) Scatterplot of $D(Y R I, X$; Norse, Iceland $)$ and D(YRI, X; Celts, Iceland $)$ for all 27 ancient Icelanders (X). To help interpret these results, we included values for ancient individuals from the British Isles and a subset of contemporary individuals (who were removed from the reference population for this analysis). (B) Estimated Norse, Celtic and Icelandic admixture proportions for the ancient Icelanders using ADMIXTURE in supervised mode with $\mathrm{K}=3$. (C) Ancient Icelanders projected onto a PCA of contemporary individuals from Scandinavia $(n=3,118)$ and the British Isles $(n=1,436)$. Variance explained by the first two components are shown in brackets. Symbols for ancient individuals are as specified in Fig. 1. 


\section{Reference and notes:}

1. The book of settlements: Landnámabók (University of Manitoba, Winnipeg, 1972).

2. K. Smith, Landnám: the settlement of Iceland in archaeological and historical perspective. World Archaeol 26, 319-347 (1995).

3. J. Steffensen, Menning og meinsemdir: ritgerđarsafn um mótunarsögu íslenskrar pjóðar og baráttu hennar við hungur og sóttir. (Ísafoldarprentsmiđja, Reykjavík, 1975).

4. G. Jones, A History of the Vikings. (Oxford Univeristy Press, Oxford, 1984).

5. S. Goodacre et al., Genetic evidence for a family-based Scandinavian settlement of Shetland and Orkney during the Viking periods. Heredity 95, 129-135 (2005).

6. A. Helgason, S. Sigurdardottir, J. R. Gulcher, R. Ward, K. Stefansson, mtDNA and the origin of the Icelanders: Deciphering signals of recent population history. Am J Hum Genet 66, 999-1016 (2000).

7. A. Helgason et al., Estimating Scandinavian and Gaelic ancestry in the male settlers of Iceland. Am J Hum Genet 67, 697-717 (2000).

8. A. Helgason et al., Sequences From First Settlers Reveal Rapid Evolution in Icelandic mtDNA Pool. PLoS genetics 5, (2009).

9. D. F. Gudbjartsson et al., Large-scale whole-genome sequencing of the Icelandic population. Nat Genet 47, 435-444 (2015).

10. A. Helgason, G. Nicholson, K. Stefansson, P. Donnelly, A reassessment of genetic diversity in Icelanders: Strong evidence from multiple loci for relative homogeneity caused by genetic drift. Ann Hum Genet 67, 281-297 (2003).

11. E. Ó. Hreiđarsdóttir, "Íslenskar perlur frá víkingaöld: með viðauka um perlur frá síđari öldum," M.A. thesis. (2005).

12. K. Eldjárn, Kuml og haugfé. A. Friđriksson, Ed., (Mál og menning, Reykjavík, 2000).

13. P. L. Ascough et al., Radiocarbon reservoir effects in human bone collagen from northern Iceland. J Archaeol Sci 39, 2261-2271 (2012). 
14. H. G. a. T. D. Price, "The settlement of Iceland; analysis of strontium isotopes on human teeth. A preliminary discussion of results". (Fornleifastofnun Íslands, Reykjavik, Iceland, 2006).

15. J. M. Enk et al., Ancient whole genome enrichment using baits built from modern DNA. Mol Biol Evol 31, 1292-1294 (2014).

16. S. Sawyer, J. Krause, K. Guschanski, V. Savolainen, S. Paabo, Temporal Patterns of Nucleotide Misincorporations and DNA Fragmentation in Ancient DNA. PloS one 7, e34131 (2012).

17. P. Skoglund, J. Stora, A. Gotherstrom, M. Jakobsson, Accurate sex identification of ancient human remains using DNA shotgun sequencing. J Archaeol Sci 40, 4477-4482 (2013).

18. C. Spatacean, "Women in the Viking Age. Death, life after death and burial customs", M.A. Thesis. (2006).

19. A. Helgason, B. Hrafnkelsson, J. R. Gulcher, R. Ward, K. Stefansson, A populationwide coalescent analysis of Icelandic matrilineal and patrilineal genealogies: Evidence for a faster evolutionary rate of mtDNA lineages than Y chromosomes. Am J Hum Genet 72, 1370-1388 (2003).

20. A. L. Price et al., The Impact of Divergence Time on the Nature of Population Structure: An Example from Iceland. PLoS genetics 5, e1000505 (2009).

21. G. Karlsson, Iceland's 1100 Years: The History of a Marginal Society. (C. Hurst, London, 2000).

22. L. M. Cassidy et al., Neolithic and Bronze Age migration to Ireland and establishment of the insular Atlantic genome. Proceedings of the National Academy of Sciences of the United States of America 113, 368-373 (2016).

23. Q. M. Fu et al., The genetic history of Ice Age Europe. Nature 534, (2016).

24. P. Skoglund et al., Genomic Diversity and Admixture Differs for Stone-Age Scandinavian Foragers and Farmers. Science 344, 747-750 (2014).

25. P. Skoglund et al., Origins and genetic legacy of Neolithic farmers and hunter-gatherers in Europe. Science 336, 466-469 (2012) 
26. D. Reich, K. Thangaraj, N. Patterson, A. L. Price, L. Singh, Reconstructing Indian population history. Nature 461, 489-494 (2009).

27. R. Martiniano et al., Genomic signals of migration and continuity in Britain before the AngloSaxons. Nature Communications 7, (2016).

28. S. Schiffels et al., Iron Age and Anglo-Saxon genomes from East England reveal British migration history. Nat Commun 7, 10408 (2016).

29. N. Patterson et al., Ancient Admixture in Human History. Genetics 192, 1065-1093 (2012).

30. E. W. Hill, M. A. Jobling, D. G. Bradley, Y-chromosome variation and Irish origins. Nature 404, 351-352 (2000).

31. A. O. Karlsson, T. Wallerstrom, A. Gotherstrom, G. Holmlund, Y-chromosome diversity in Sweden - a long-time perspective. Eur J Hum Genet 14, 963-970 (2006).

32. T. D. Price, H. Gestsdottir, The first settlers of Iceland: an isotopic approach to colonisation. Antiquity 80, 130-144 (2006).

\section{Acknowledgments:}

SSE and VBG received grants from The Research Fund of University of Iceland for doctoral studies. AJ received a grant from EUROTAST Marie Curie Framework Programme 7 Initial Training Network (290344). MSE received a grant from the Icelandic Research Fund (163428-051). We thank the staff at the National Museum of Iceland for their help.

\section{Author contributions:}

SSE, KS and AH designed and directed the research. SSE and AH analysed the data, with EDG, AJ, VBG, ELT, MSE, HJ, SG and MTPG providing assistance with particular tasks. SSE and MS-V generated the ancient genomic data with laboratory guidance and support 
from ÁS, DNM, SS, CL-F, ÓPS and MTPG. Modern reference datasets were provided by EH, PM, IK, TO, KA, TFH, TW, GLC and EG. Archaeological and osteological context was provided by JWW, SK and LÁ, who also provided access to samples. SSE, KS and AH wrote the manuscript and supplements with input from MS-V, MTPG, HJ, KHSM and SS.

\section{Competing financial interests:}

Authors affiliated with deCODE Genetics are employed by the company, which is owned by Amgen, Inc.: SSE, EDG, AJ, VBG, ELT, MSE, KHSM, ÁS, DNM, HJ, SS, ÓPS, KS and AH.

\section{Supplementary Materials}

Materials and Methods

Supplementary Text

Figs. S1 to S7

Tables S1 to S11

References (33-69) 


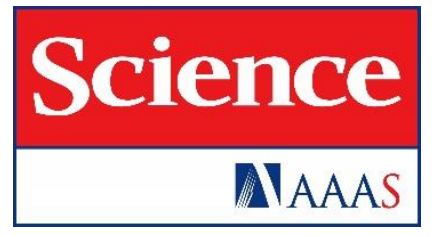

\section{Supplementary Materials for}

\section{Ancient genomes from Iceland reveal the making of a human population}

S. Sunna Ebenesersdóttir, Marcela Sandoval-Velasco, Ellen D. Gunnarsdóttir, Anuradha Jagadeesan, Valdís B. Guðmundsdóttir, Elísabet L. Pórðardóttir, Margrét S. Einarsdóttir, Kristján H. S. Moore, Ásgeir Sigurðsson, Droplaug N. Magnúsdóttir, Hákon Jónsson, Steinunn Snorradóttir, Eivind Hovig, Pål Møller, Ingrid Kockum, Tomas Olsson, Lars Alfredsson, Thomas F. Hansen, Thomas Werge, Gianpiero Cavalleri, Edmund Gilbert, Carles

Lalueza-Fox, Joe W. Walser III, Steinunn Kristjánsdóttir, Shyam Gopalakrishnan, Lilja Árnadóttir, Ólafur P. Magnússon, M. Thomas P. Gilbert, Kári Stefánsson and Agnar Helgason

correspondence to: $\underline{\text { sunna@ @ecode.is }}$ (SSE); $\underline{\text { agnar.helgason@ decode.is }}(\mathrm{AH})$; kstefans@decode.is $(\mathrm{KS})$

This PDF file includes:

Materials and Methods

Supplementary Text

Figs. S1 to S8

Tables S1 to S11

References (33-69) 
SUPPLEMENTARY TEXT: TABLE OF CONTENTS

S1. Archaeological information 3

Selection of skeletal remains 3

Archaeological context summaries 4

$\begin{array}{ll}\text { S2. Ancient DNA processing } & 7\end{array}$

$\begin{array}{ll}\text { DNA extraction } & 7\end{array}$

$\begin{array}{ll}\text { DNA library preparation, enrichment and sequencing } & 7\end{array}$

$\begin{array}{lr}\text { Processing and alignment of reads } & 9\end{array}$

S3. Quality control $\quad 10$

$\begin{array}{ll}\text { Error rate estimates } & 10\end{array}$

$\begin{array}{ll}\text { MapDamage } & 10\end{array}$

$\begin{array}{ll}\text { mtDNA motifs and contamination estimates } & 10\end{array}$

$\begin{array}{ll}\mathrm{X} \text { chromosome contamination } & 10\end{array}$

$\begin{array}{ll}\text { Genetic sex determination } & 11\end{array}$

S4. Population genomics $\quad 12$

Reference population datasets 12

$\begin{array}{ll}\text { Y chromosome analysis } & 13\end{array}$

$\begin{array}{lr}\text { Principal components analysis } & 13\end{array}$

$\begin{array}{ll}\text { D-statistics test } & 13\end{array}$

$\begin{array}{ll}\text { Admixture } & 13\end{array}$

$\begin{array}{ll}\text { Supplementary figures } & 14\end{array}$

Supplementary tables $\quad 24$

References $\quad 47$ 


\section{S1. Archaeological information}

\section{Selection of skeletal remains}

For this study, 35 ancient Icelandic skeletal remains were screened for DNA preservation. The remains were unearthed during the period 1900-1996 A.D. and are stored at the National Museum of Iceland. Details of the sampled individuals are given in Table S1. Several factors that contributed to the initial sample selection process are discussed below.

(1) Dating evidence: We focused on human remains dating to or shortly after the settlement of Iceland (870-930 A.D). The replacement of the Old Norse religion by Christianity around 1000 A.D. entailed major changes in burial customs. In Christian burials, the dead were typically laid in coffins in relatively large cemeteries, with graves in an east-west orientation. However, pre-Christians were buried according to Old Norse customs in peripheral sites called kuml. They are usually found as single inhumations, with the body lying on its side in a northsouth orientation. A key factor in identifying a pre-Christian burial site is the presence of grave goods, which were typically buried with the deceased to be used by them in the afterlife. Typical grave goods include animals, boats, weapons, jewelry and household items (12). The archaeological classification of a burial site can effectively be used to date the death of an individual to either the pre-Christian period ( 870-1000 A.D.) or the Christian period (>1000 A.D). This dating method is well supported by results from both radiocarbon dating and datable grave goods $(11,13,14,32)$.

(2) Place of development: We preferentially selected remains that had been subjected to enamel strontium isotope analysis. The enamel of adult teeth is formed in early childhood, and because the ratio of isotopes 87 and $86\left({ }^{87} \mathrm{Sr} /{ }^{86} \mathrm{Sr}\right)$ absorbed by organisms varies geographically, they can be used to infer the provenance of human remains (33). In particular, the relatively large geological difference between ${ }^{87} \mathrm{Sr} /{ }^{86} \mathrm{Sr}$ in Iceland and the rest of Europe allows for inferences about whether remains found in Iceland were from an individual who spent their first years there or elsewhere $(14,32)$. It is very likely that that an individual who, according to burial features, died before 1000 A.D., and whose enamel displays a ${ }^{87} \mathrm{Sr} /{ }^{86} \mathrm{Sr}$ value indicative of being born and bred outside of Iceland, was a first generation settler.

(3) Geographical location and archaeological relevance: We selected samples unearthed from widely geographically distributed sites to best represent the population of Iceland during the settlement period (Main text Fig. 1). We sampled multiple remains from three sites which contained more than one burial. (DAV: 3, SSG: 4, and VDP: 4).

Other practical issues contributed to our selection of samples, such as the availability of remains and their quality. All the remains analyzed in this paper were sampled for a previous study of Helgason et al. (34), in which one tooth (usually a molar or premolar) was sampled from each of the remains. Frozen DNA extracts were available for many of the samples; in some cases, frozen ground tooth samples were also available. For sequencing, we prioritized samples that had a sufficient volume of DNA extract and/or ground tooth for fresh extraction. Prioritization was also influenced by the quality of each sample, assessed based on success in PCR amplification and clonal sequencing of mtDNA sequences in the previous study (34). 


\section{Archaeological context summaries of ancient Icelandic skeletal remains}

Here, we provide a summary of archaeological context of the sites and remains that were sampled for this study. More detailed information about the pre-Christian sites can be found in the reference publication Kuml and Haugfé (12).

Dalvík (Brimnes) [DAV]: A pre-Christian burial site was found in 1908 and excavated the following year. It is one of the largest and most studied pre-Christian burial sites in Iceland. Thirteen human skeletal remains, six horse skeletons, and the remains of three dogs were found at the site. In one of the graves, the deceased had been placed in a sitting position at the rear of a boat. We selected three samples for sequencing from this site: DAV-A7, DAV-A8 and DAVA9.

Öndverðarnes [DKS]: In 1962, a human skeleton (DKS-A1) was discovered during road construction. Grave goods included a sword, a spearhead, a knife, a shield-boss, a bone-pin, and fragments of iron. According to a morphological analysis, the skeletal remains show evidence of developmental delay that could be explained by hypogonadism caused by Klinefelter syndrome, testicular disorder or castration (35).

Einholt [EIM]: In 1979 a pre-Christian burial was found near a farmhouse. The remains of a female skeleton (EIM-A1), along with grave goods, were found at the site.

Fossvellir [FOV]: A single human skeleton (FOV-A1) was found by bridge builders near the bridge over Jökulsá á Brú in 1929. The remains seem to have been placed at the site after the individual was deceased. The bones had been carefully arranged on top of each other and were surrounded by stone slabs and turf. The remains are of unknown temporal origin. However, there have been some speculations about who the deceased might have been. It has been claimed that these are the remains of a silver salesman who was thought to have disappeared (possibly murdered) in this area in $1830(36,37)$. However, it is also known that there was a parliament site (ca. 1624-1800) in close proximity, where individuals convicted of serious crimes were executed (37).

Fremri-Svartárdalur [FSS]: In 1960, an eroded burial was found around 150 meters from an old farmstead, which contained a human skull and a few other bones (FSS-A1). No grave goods were found at the site, which had clearly been disturbed previously. The site is classified as preChristian.

Gilsárteigur [GTE]: In 1949, field-leveling exposed a pre-Christian burial site near an old farm site. The remains of two skeletons were excavated in 1957. Both burials contained grave goods. One of the remains (GTE-A1) found at the site was screened for DNA preservation.

Grímsstaðir [GRS]: Three pre-Christian burials were found in close proximity to each other near the site of a farmstead. We analysed one of the skeletal remains (GRS-A1), which were excavated in 1937. No grave goods were found at the site.

Grímsstaðir 'the old' [GRF]: In 1962 an eroded pre-Christian burial site revealed the skeletal remains of three individuals along with a spear-head. We sequenced one of the remains (GRFA1) excavated from this site. 
Hafurbjarnarstaðir [HBS]: An eroded pre-Christian burial site was discovered in 1828 and excavated in 1947. The remains of seven to eight individuals (one child, two females and four to five individuals whose sex could not be identified by morphological analysis) were found at the site. Grave goods were found at the site, along with dog and horse bones. We analysed a sample from skeletal remains found in one of the burials (HBS-A1).

Hrólfsstaðir [HSJ]: In 1996, human skeletal remains (HSJ-A1) were unearthed by a bulldozer. This pre-Christian site had clearly been disturbed before. A comb, knife, and pieces of charcoal were found in the grave.

Karlsnes [KNS]: Human skeletal remains (KNS-A1) were found in an eroded pre-Christian burial site in 1932. There are no records of a farm having existed nearby. The remains, which were in a supine position, appeared to have been undisturbed since burial. Grave goods included a spearhead, a knife, two lead weights, three beads, and a small stone.

Kópavogur [KOV]: In 1988, two skeletal remains were excavated during road constructions in Kópavogur. Based on archaeological evidence, the remains were identified as a female, born 1664, and a male, born 1678. According to historical records (38), they were executed in 1704 for the murder of the female's husband. The male was beheaded, and his impaled head publicly exhibited, whereas the female was drowned. Their remains were buried buried in unconsecrated ground at a site called Hjónadysjar. The remains of the male (KOV-A2) were selected for sequencing in this study.

Kroppur [KRE]: During road work in 1900, two pre-Christian skeletal remains were revealed west of a farm. Grave goods were found in both graves. We sequenced one of the remains (KRE-A1) found at the site.

Neðri-Pverá [NPR]: In 1949, two human skulls were found near a farm site. No grave goods were found, but archaeologists concluded that it was likely a badly eroded pre-Christian burial site. The remains of NPR-A2 were selected for sequencing.

Njarovík [NNM]: In 1981, a human skull (NNM-A1) was found at a site considered to be a badly damaged pre-Christian burial.

Ormsstaðir [ORE]: In 1966, a pre-Christian site near an old farmstead was excavated after being exposed during field leveling. One human skeleton (ORE-A) was found, along with an axe, a knife, and three lead weights. A single human bone from another individual was found nearby.

Skeljastaðir [PSK]: The remains of PSK-A26 are from the Christian cemetery at Skeljastaðir in Pjórsárdalur, excavated in 1939. The remains are dated to before 1104 A.D., as the site was abandoned in the wake of a volcanic eruption of Mount Hekla in that year (39).

Sílastaðir [SSG]: A cluster of four pre-Christian graves was discovered in 1947. Based on morphological analysis, three of the skeletons were deemed male, and one female. We selected all four remains for sequencing: SSG-A1, SSG-A2, SSG-A3 and SSG-A4.

Smyrlaberg [SBT]: In 1952, a pre-Christian burial site was found in an old gravel quarry. Two years later its excavation revealed a male skeleton (SBT-A1) and an iron knife. Another grave, badly damaged, was found nearby, but only fragments of bone could be identified within 
Straumur [STT]: In 1952, a pre-Christian burial site was excavated, which included the remains of four individuals (one child, one male, one female, and another adult whose sex could not be determined by morphological analysis). Grave goods included a horse bone, a small axe, thirty boat rivets, a lead weight, two pebbles and a knife. We selected STT-A2 for sequencing.

Suðurárbotnar [SUB]: An eroded grave containing two skulls and a few bones, thought to be pre-Christian, was discovered in 1947 . We selected SUB-A1 for sequencing.

Surtsstaðir [SSJ]: In 1945, an eroded and previously disturbed pre-Christian burial was found and excavated four years later. The remains of two individuals were found at the site, along with grave goods. We selected SSJ-A2 for sequencing.

Svínadalur [SVK]: In 1961, human skeletal remains (SVK-A1) were brought to the National Museum. They had been exposed for many years near an old farmhouse. There were no grave goods found at the site, but the remains are thought to be pre-Christian.

Tunga í Göngusköroum [TGS]: Human skeletal remains (TGS-A1) of unknown temporal origin were excavated in 1981 by inhabitants at a nearby farm.

Vatnsdalur [VDP]: In 1964, a pre-Christian boat grave was discovered by chance at this site. In it were seven previously disturbed human skeletal remains (three females and four male), along with a dog skeleton. Grave goods included a knife, thirty beads, a silver Thor's hammer, a fragmented Cufic coin (ca. 870-930 AD), and jewelry. We sequenced four of the remains found at the site (VDP-A3, VDP-A5, VDP-A6 and VDP-A7).

Viðar (Másvatn) [MKR]: In 1989, human skeletal remains (MKR-A1) were revealed during road work. The remains are thought to be from a pre-Christian burial site, dated to pre-1477 based on volcanic ash chronology.

Ytra-Garðshorn [YGS]: In 1952, a pre-Christian burial site was discovered during road construction east of a farm and excavated two years later. The site included the disturbed remains of nine human skeletons (four males, two females, one child and two individuals whose sex have not be inferred based on morphological analysis). This site is one of the largest preChristian burial sites discovered in Iceland. There were grave goods in all graves. We selected one of the remains (YGS-B2) for sequencing. 


\section{S2. Ancient DNA processing}

\section{DNA extraction}

Extraction of DNA was conducted in dedicated aDNA clean laboratory facilities located several kilometers from the main deCODE site in Reykjavik. Surfaces of the laboratory and equipment were cleaned repeatedly with bleach, and full body suits, gloves, hoods and facemasks were worn at all times. Blank controls were incorporated in extractions, library preparations and each step of PCR to monitor for contamination.

Prior to this study, all sampled teeth $(n=36)$ were ground to powder using an analytical mill, followed by DNA purification with phenol-chloroform, as described elsewhere $(8,34)$. All remaining extraction aliquots and/or ground teeth were stored at $-20^{\circ} \mathrm{C}$. In total, 32 samples had enough DNA extraction aliquot remaining $(>20 \mu \mathrm{L})$ for at least one library build. In addition, 17 new DNA extracts were made from ground tooth samples using a modified version of the silica-in-solution method based on Rohland and Hofreiter (40), with adjustments (41) (Table S2). The amount of ground tooth varied, but was generally 200-400 mg. A brief description of the method follows. The powdered samples were incubated for 24 hours at $37^{\circ} \mathrm{C}$ in $5 \mathrm{ml}$ of an EDTA-based digestion buffer containing $0.25 \mathrm{mg} / \mathrm{mL}$ Proteinase K. Following digestion, the DNA was bound to a silica suspension in the presence of chaotropic salts. For this step, we used the Dabney et al. (41) binding buffer recipe. The pellets were then washed twice in $1 \mathrm{ml} 80 \% \mathrm{EtOH}$, and DNA was eluted in $80 \mu \mathrm{L}$ low-salt EB buffer (Qiagen, Valencia, California). We kept any undissolved bone powder, binding supernatant and the silica pellet, and stored it with the aliquots of DNA extracts at $-20^{\circ} \mathrm{C}$.

\section{DNA library preparation, enrichment and sequencing}

For each sample, between 20-30 $\mu \mathrm{L}$ of extracted DNA was converted to a double-stranded library using NEBNext ® DNA Library Prep Master Mix set for 454 (catalog number E6070L, New England BioLabs, Ipswich, Massachusetts). One to two libraries were built per extract, resulting in 61 libraries (1 to 4 libraries per individual) (Table S2). All libraries were prepared according to the manufacturer's instructions, with a few modifications and adjustments listed below. The extracts were not nebulized as aDNA is already highly fragmented in nature. The protocol consists of three modules. In the first module, DNA was blunt ended in a $50 \mu \mathrm{L}$ reaction using $5 \mu \mathrm{L}$ of NEBNext 10x end repair buffer and $2.5 \mu \mathrm{L}$ of NEBNext End Repair Enzyme Mix (T4 polynucleotide kinase and T4 DNA polymerase). The samples were then incubated in a thermal cycler for 20 minutes at $12^{\circ} \mathrm{C}$, followed by 15 minutes at $37^{\circ} \mathrm{C}$. Following this, the reactions were purified in MinElute silica spin columns (Qiagen, Valencia, California), using $5 \times$ PB binding buffer and $720 \mu \mathrm{L}$ of PE wash buffer. Samples were eluted in $30 \mu \mathrm{L}$ of EB buffer, with an incubation step at $37^{\circ} \mathrm{C}$ for 15 minutes. All centrifugation steps were conducted at $16,000 \times g$. In the second module, Illumina-specific adapters, prepared following the protocol described by Meyer and Kircher (42), were ligated to the blunt-ended DNA. Ligation of adapters was conducted in $50 \mu \mathrm{L}$ reactions using $10 \mu \mathrm{L}$ of NEBNext $5 \times$ quick ligation buffer, $5 \mu \mathrm{L}$ of Quick T4 DNA ligase and $0.25 \mu \mathrm{M}$ as final adapter concentration. Reactions were incubated in a heat block for 20 minutes at $20^{\circ} \mathrm{C}$. After ligation, reactions were purified as above, with the exception of being eluted in $42 \mu \mathrm{L}$ of EB buffer in this step. In the third module, remaining DNA nicks were repaired, and the fill-in procedure was conducted in a $50 \mu \mathrm{L}$ reaction using $3 \mu \mathrm{L}$ of $B s t$ DNA polymerase and $5 \mu \mathrm{L}$ of NEBNext adapter Fill-in reaction buffer, along with the adapter-ligated DNA from above. Reactions were incubated in a thermal cycler for 20 minutes at $65^{\circ} \mathrm{C}$, followed by 20 minutes at $80^{\circ} \mathrm{C}$ to inactivate the Bst enzyme. Once molecules had been ligated to suitable adapters and the PCR setup was finished, 
the libraries were handled outside of the clean room facilities.

The libraries were amplified in $100 \mu \mathrm{L}$ PCR reactions containing $25 \mu \mathrm{L}$ of library template, 5 U AmpliTaq Gold Polymerase (Applied Biosystems, Foster City, CA), 1× AmpliTaq Gold Buffer, $2.5 \mathrm{mM} \mathrm{MgCl} 2,0.8 \mathrm{mg} / \mathrm{mL}$ BSA, $200 \mu \mathrm{M}$ dNTPs, and $200 \mathrm{nM}$ of forward, and reverse indexing primers (Meyer and Kircher, 2010). Thermocycling conditions were 10 min at $95^{\circ} \mathrm{C}$, followed by 14 cycles of 20 secs at $95^{\circ} \mathrm{C}, 30$ secs at $60^{\circ} \mathrm{C}$, and 40 secs at $72^{\circ} \mathrm{C}$, and a final 5 min elongation step at $72^{\circ} \mathrm{C}$. Samples were eluted in $31 \mu \mathrm{L}$ of EB buffer, with an incubation step at $37^{\circ} \mathrm{C}$ for 15 minutes.

Amplified indexed libraries were purified in QiaQuick silica spin columns using $5 \times \mathrm{PB}$ binding buffer and $720 \mu \mathrm{L}$ of PE wash buffer. Samples were eluted in $30 \mu \mathrm{L}$ of EB buffer, with an incubation step at $37^{\circ} \mathrm{C}$ for $15 \mathrm{~min}$. After purification, $1 \mu \mathrm{L}$ of each library was measured on an Agilent 2100 Bioanalyzer with High Sensitive DNA Analysis Kit (Santa Clara, California). Six libraries were excluded after first amplification on the basis of low molar concentration $(<100 \mathrm{pmol} / \mathrm{L}$ ) (Table S2). If needed, samples were reamplified for 4-10 cycles to obtain $\geq 100 \mathrm{ng}$ of library template. Reamplification of libraries were performed in $100 \mu \mathrm{L}$ PCR reactions, containing $25 \mu \mathrm{L}$ of DNA template, $1 \times$ Phusion ${ }^{\circledR}$ High-Fidelity PCR Master Mix with GC Buffer (NEB), 2.5\% DMSO, $0.2 \mu \mathrm{M}$ agnostic primers IS5 (5'- AATGATACG GCGACCACCGA) and IS6 primers (5'- CAAGCAGAAGACGGCA TACGA) (42), and $\mathrm{H}_{2} \mathrm{O}$. Thermocycling conditions were $3 \mathrm{~s}$ at $98^{\circ} \mathrm{C}$, followed by $20 \mathrm{~s}$ at $98^{\circ} \mathrm{C}, 30 \mathrm{~s}$ at $60^{\circ} \mathrm{C}, 30 \mathrm{~s}$ at $72^{\circ} \mathrm{C}$, with a final 5 min elongation step at $72^{\circ} \mathrm{C}$.

With the purpose of screening for endogenous DNA content, the double-stranded DNA libraries were pooled in equimolar concentrations by the values obtained by quantification and sequenced on Illumina MiSeq ( $2 \times 150$ cycles +7 cycle index run). Based on the initial screening, two libraries (27_P2 and 52_P1) were excluded due to their low proportion of human reads (< 1\%) (Table S2). However, several new libraries were constructed from the most efficient samples. Following molecular screening, 51 candidate libraries were selected for enrichment (15) (Table S2) using the MyBait Human Whole Genome Capture Kit (MYbaits-HuWGE) from MYcroarray (Ann Arbor, Mi) (15). Selection was performed following the manufacturer's instructions for version 1.3.8 of the MyBait user manual, along with a few modifications from Version 2.3.1. The libraries were concentrated to the required volume using a SpeedVac (Savant Plus Model SC210A-120). Bait library hybridization was left for 24 hours at $65^{\circ} \mathrm{C}$. Instead of releasing the captured DNA target molecules from the RNA baits using a $\mathrm{NaOH}$ treatment (as suggested in version 1.3.8), we resuspended the beads with $30 \mu \mathrm{L}$ Molecular Biology Grade Water, and amplified the enriched DNA directly after recovering the targets.

After enrichment, libraries were amplified for 14-16 cycles in $50 \mu \mathrm{l}$ PCR reactions, containing $15 \mu \mathrm{L}$ of enriched library as template, $1 \times$ KAPA HotStart ReadyMix, $0.8 \mathrm{mg} / \mathrm{mL}$ BSA, $0.3 \mu \mathrm{M}$ agnostic primers IS5 and IS6 (42) (5'-CAAGCAGAAGACGGCATACGA) and the same PCR set-up condition as above. Following amplification, the enriched libraries were purified and quantified using the same method as before. Next, they were pooled together and sequenced on Illumina MiSeq platform $(2 \times 150 \mathrm{bp})$. We required the endogenous DNA to be $>15 \%$ to be sequenced further. Seven libraries did not meet this criterion and were excluded (Table S2). In total, 46 libraries, including four from pre-capture, were paired-end sequenced on the Illumina HiSeq2500 ( $2 \times 100 \mathrm{bp})(\geq 1$ lane) platform. One to five lanes were sequenced per library, resulting in a total of 85 HiSeq lanes (Table S3). 


\section{Processing and alignment of reads}

Nucleotide base calling and quality score assessment was performed using specific Real Time Analysis (RTA) software provided by Illumina. Due to postmortem degradation, aDNA fragments are usually very short, resulting in sequencing of the adapter, which has been ligated during the library preparation. Thus, AdapterRemoval v.1.5 (43) was used to remove adapter sequences, as well as stretches of consecutive low quality bases and N's. We required trimmed reads to be at least $25 \mathrm{bp}$ for alignment. Alignment was performed to NCBI build 38 of the human reference genome using Burrows-Wheeler Algorithm (BWA) v. 0.7.10, (44) with the seed disabled (-1 1024) to improve accuracy and the minimum base quality set to 15. Data was merged into library level and duplicated using Picard (PicardTools v.1.79, http://broadinstitute.github.io/picard/). Reads with mapping quality inferior to 30 (SAMtools v.1.5) (45) were discarded before remerging to sample level. Read depth and coverage were determined using BEDtools-2.18.2 (46) and an in-house python script. Finally, base quality scores were rescaled with mapDamage 2.0 (47) to exclude likely-damaged bases $(\mathrm{q}<30)$. Ancient genomes from previous published studies $(22,27,28)$ (Table S8) were processed in the same way after their BAM files were downloaded. 


\section{S3. Quality control}

\section{Error rate estimates}

The error rates were estimated for each of our ancient human samples with ANGSD (48) v. 0.911 (48) using a high quality 'error free' human genome and a human outgroup. The estimation is based on the idea that any excess of derived alleles for the ancient sample compared to the high quality genome is due to errors, since they should have the same expected number of derived alleles compared to the outgroup (49). We used an inferred ancestor of Homo sapiens (50) and a randomly sampled high quality (30X) whole genome sequenced at deCODE Genetics. Type-specific error rates and overall error rates are shown in Fig. S1. Both estimation methods show that the most dominant errors in our ancient samples are transitions $(\mathrm{C} \rightarrow \mathrm{T}$, $\mathrm{G} \rightarrow \mathrm{A}$ ) typical of ancient DNA damage caused by post-mortem deamination of cytosine.

\section{MapDamage}

To verify the authenticity of our samples, the existence of nucleotide misincorporation was investigated using the Bayesian approach implemented in mapDamage 2.0 (47). An increase in $\mathrm{C} \rightarrow \mathrm{T}$ transitions at the at the $5^{\prime}$ end was observed in reads from all samples, which is consistent with the presence of authentic aDNA (Fig. S2).

\section{mtDNA motifs and contamination estimates}

Although mtDNA is a circular molecule, mapping algorithms treat the ends of the artificially linear mtDNA reference genome as unconnected. There is therefore a bias against the mapping of paired-end reads in these locations. To circumvent this bias, reads mapped to the rCRS were remapped to an extended version of the linear rCRS reference sequence (51), obtained by adding the first $500 \mathrm{bp}$ to the end and the last $500 \mathrm{bp}$ to the start (45). All mitochondrial consensus sequences were identical to the ones previously reported for the mtDNA control region (sites 16517 to 409 and 16055 to 16410) obtained using PCR and cloning, which were partly based on different DNA extractions (34). After calling consensus mtDNA sequences, we estimated the contamination affecting mtDNA by estimating the frequency of minor alleles at positions where the major allele was rare $(<5 \%)$ in a large sample of contemporary Icelanders $(n=30,219)$. If no alternative allele was found, we allowed for $10 \%$ minor allele frequency. A point estimate $c$ of mtDNA contamination was estimated following Skoglund et al. (17), assuming independence of the bases: $\hat{c}=\mathrm{N}_{\text {alternative }} /\left(\mathrm{N}_{\text {consencus }} \mathrm{N}_{\text {alternative }}\right)$. Estimates are listed in Table S5.

\section{X chromosome contamination}

We used the 'Contamination' program in ANGSD (48) v.0.911 to estimate X chromosome contamination, as described in (52). As the $\mathrm{X}$ chromosome is haploid in males, mismatches at polymorphic sites are either due contamination or error in sequencing or mapping. Assuming that sequencing errors are randomly distributed across the genome, the discordance in the rate of heterozygous calls between known polymorphic sites and their adjacent monomorphic sites is evaluated to assess the level of contamination. We used default parameters and the provided mapFile and hapFile (after liftover to NCBI build 38) based on fixed set of SNPs known to be polymorphic in Europeans (HapMap) to define our polymorphic sites, and restricted the analysis to the non-recombining portion of the $\mathrm{X}$ chromosome. We only considered bases with 
quality $\geq 20$ and reads with mapping quality $\geq 30$. ANGSD applies two different methods to estimate the contamination rate: Method 1 considers all bases, providing greater power, while assuming that errors are independent between reads and sites. However, Method 2 does not have this bias, as it randomly samples a single read at each site, but is also less precise than Method 1. Contamination estimates are shown in Supplementary Table S5. Low X chromosome contamination estimates $(<3.6 \%)$ were observed in all samples used in this study (median $=0.64 \%)$.

\section{Genetic sex determination}

We used the ratio of reads mapping to the $\mathrm{Y}$ and $\mathrm{X}$ chromosomes to determine the sex of each sample as described in Skoglund et al. (17). To do so, we calculated $R_{y}$, the fraction of reads mapping to the $\mathrm{Y}$ chromosome compared to the total number of reads mapping to both the $\mathrm{Y}$ and the $\mathrm{X}$ chromosomes. We used this value to assign each sample XX or XY karyotypes. Results are shown in Fig. S3A and Table S6. 


\section{S4. Population genomics}

\section{Reference population datasets}

We compiled two main autosomal reference datasets of microarray SNP data for the purpose of analyzing the ancestry of the ancient Icelanders. We removed loci and individuals with $<95 \%$ call rate, and loci that failed Hardy-Weinberg Equilibrium exact tests with p-value $<0.0001$. We ran ADMIXTURE (53) with individuals of Asian and African ancestry and filtered out individuals with $<90 \%$ European ancestry. Finally, the reference datasets were filtered for related individuals, defined as pairs with IBD values $>0.06$. The remaining SNPs were subsequently pruned for loci on three previously reported long range LD regions on chromosomes 6, 8 and 11 using PLINK (54).

Our European reference dataset contained genotypes for 227,056 loci (the intersection of several different Illumina chip types) from 2,139 contemporary individuals sampled from 29 European populations. Of these, 1166 individuals were from previously published datasets (5559), with the remainder from this study (Table S7). Our second reference dataset contained 404,066 SNPs from 5,470 contemporary individuals from the North Atlantic. Of these, 1,246 were individuals from the United Kingdom and Ireland from the previously published People of the British Isles (POBI) dataset (60) (Table S7). We selected individuals from the POBI dataset that had been genotyped on both the Illumina HumanHap 1M chip and Affymetrix 500K to maximize the intersection of SNPs with the remaining samples $(n=4,224)$, which were all genotyped on the Illumina OmniExpress chip. We included 190 Irish individuals from the Irish DNA Atlas dataset(61), a collection of individuals who have all eight great-grandparents born within $50 \mathrm{~km}$ of each other in different counties of Ireland. Saliva samples were obtained (Oragene OG-250, DNA Genotek, Canada), and extracted according to standard protocol, before genotyping on the Illumina OmniExpress chip at Edinburgh Genomics. The remaining samples $(n=4,034)$ were genotyped on the Illumina OmniExpress chip at deCODE Genetics. The Danish samples ( $n=980)$ were recruited in 2011 among blood donors in the area of Greater Copenhagen, Denmark. All participants were healthy with no known illness, for the majority $(85 \%)$, parents and grandparents were born in Denmark. The Swedish samples $(n=1,103)$ are population-based controls collected as part of the case-control study "epidemiology of multiple sclerosis (EIMS)" (62). The Norwegian samples $(n=1,035)$ are unrelated controls from an ongoing study of heritable cancer genes, who were sampled from all the major regions of Norway. The Icelandic samples $(n=916)$ were randomly selected from a larger set of individuals genotyped on the Illumina OmniExpress chip as a part of ongoing research at deCODE into the genetic basis of human phenotypic variation. All sample identifiers were encrypted in accordance with the regulations of the Icelandic Data Protection Authority.

The genotype data from Norway, Sweden and Denmark are from controls used in ongoing GWAS studies, and as such are subject to some access restrictions. Further information can be obtained from Eivind Hovig (ehovig@ifi.uio.no) regarding the Norwegian data, Thomas Werge regarding the Danish data (Thomas.Werge@regionh.dk) and Tomas Olsson (Tomas.Olsson@ki.se) regarding the Swedish data. Icelandic law and the regulations of the Icelandic Data Protection Authority prohibit the release of individual-level and personally identifying data. Access to the genotype data from contemporary Icelanders is contigent on an application to deCODE Genetics and travel to its Icelandic facilities. 


\section{Y chromosome analysis}

We used the ISOGG $2016 \mathrm{Y}$ chromosome tree (63) to assign haplogroups to the 22 ancient Icelanders identified as males, along with 3,018 males from the North European reference data set (main Table 1 and Table S10). The ISOGG 2016 database is based on 13,793 loci, each of which marks a mutation on the human Y chromosome tree. For each SNP in the dataset, we determined whether our ancient sample carried the derived or ancestral allele (according to majority alleles with base quality $>30$ ), and assigned each individual to the branch in the tree most consistent with the overall configuration of derived alleles observed.

\section{Principal components analysis}

For the two reference data sets of contemporary individuals described above, PCAs were computed using the 'smartpca' (64) program from the EIGENSOFT v.6.01 package. The PC weights for each locus were then used to calculate projected eigenvector values based on haploid genotypes from the ancient individuals (20, 64). Using the R package "vegan" (http://vegan.r-forge.r-project.org/)., we also used Procrustes transformation (65) to combine separate PCA analyses for each ancient individual against a given reference set of contemporary individuals.

\section{D-statistics test}

We used D-statistics to explore the patterns of shared genetic drift between ancient and contemporary individuals in our data set. The statistics were calculated with the ADMIXTOOLS package v. 3.0 (29), based on allele frequencies using the estimators described previously. Significant deviation from zero can be interpreted as rejection of the tree population typology ((Outgroup, X);(Pop1, Pop2)). Under the assumption that no gene flow occurred between Pop1 and Pop2 and the outgroup, a positive D-statistic suggests affinity between X and Pop2, whilst a negative value indicates affinity between X and Pop1. Standard errors were obtained using a block jackknife $5 \mathrm{cM}$ in size, and D-statistic values were considered significantly different from 0 when absolute Z-scores were $>3(26,66,67)$.

\section{Admixture}

To assess the different proportions of Norse, Celtic and Icelandic ancestry in our ancient individuals, we used ADMIXTURE v.1.3 (53). Unsupervised ADMIXTURE analysis for various values of $\mathrm{K}$ did not yield clear clusters corresponding to Celts, Norse and Icelanders. This is most likely due to the fact that the Norse and Celtic populations are very closely related, and that the Icelanders are both admixed and separated from their source populations by genetic drift. We therefore resorted to a supervised approach (68), where we estimated admixture proportions for the ancient Icelandic individuals using Norse and Celtic reference populations with $\mathrm{K}=2$, and Norse, Celtic and Icelandic references with $\mathrm{K}=3$. These analyses were run on haploid data. We also estimated admixture proportions for contemporary Icelanders $(n=916)$ using ADMIXTURE in supervised mode with Norse and Celtic reference populations $(\mathrm{K}=2)$. 


\section{Supplementary figures}

A

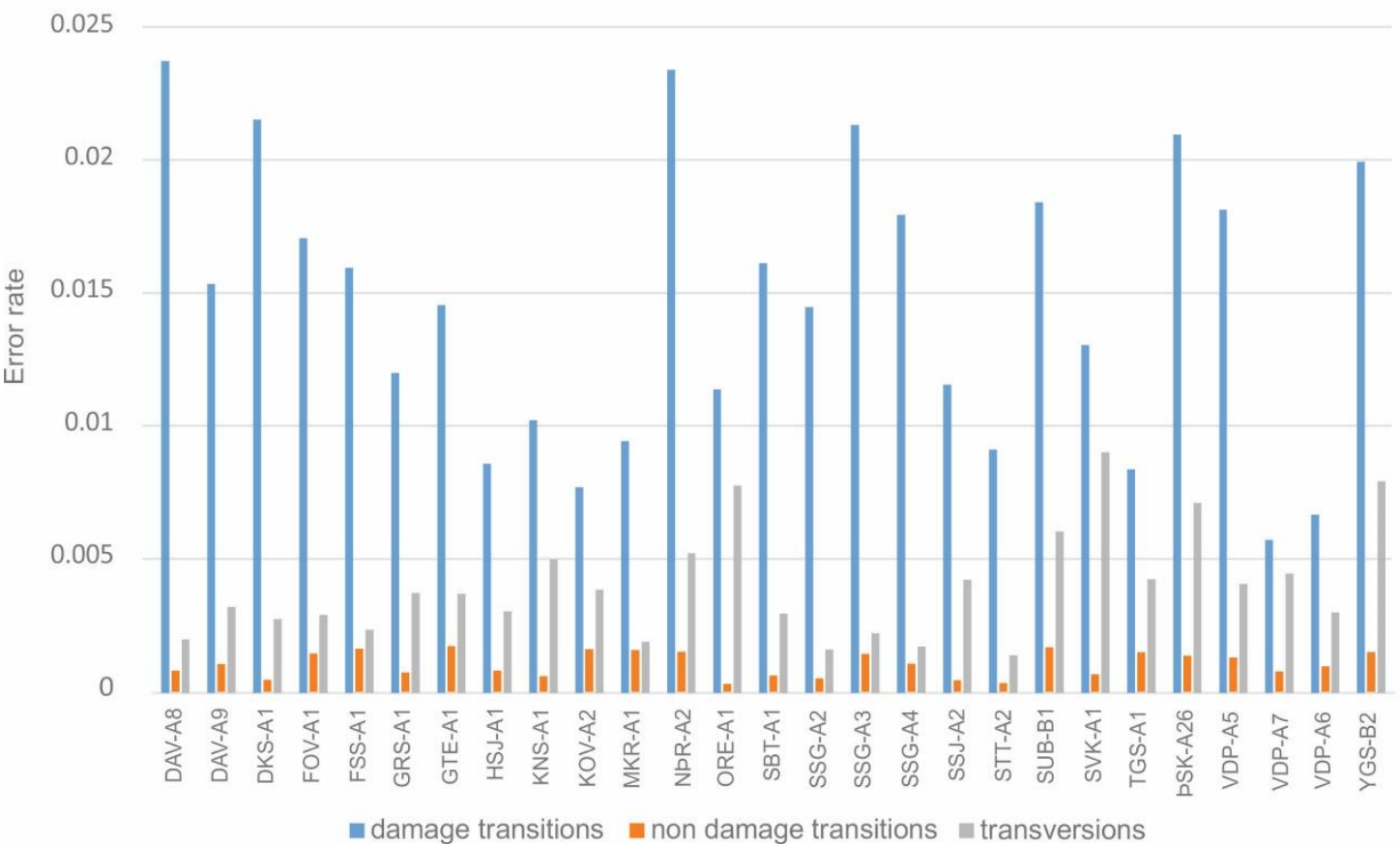

B

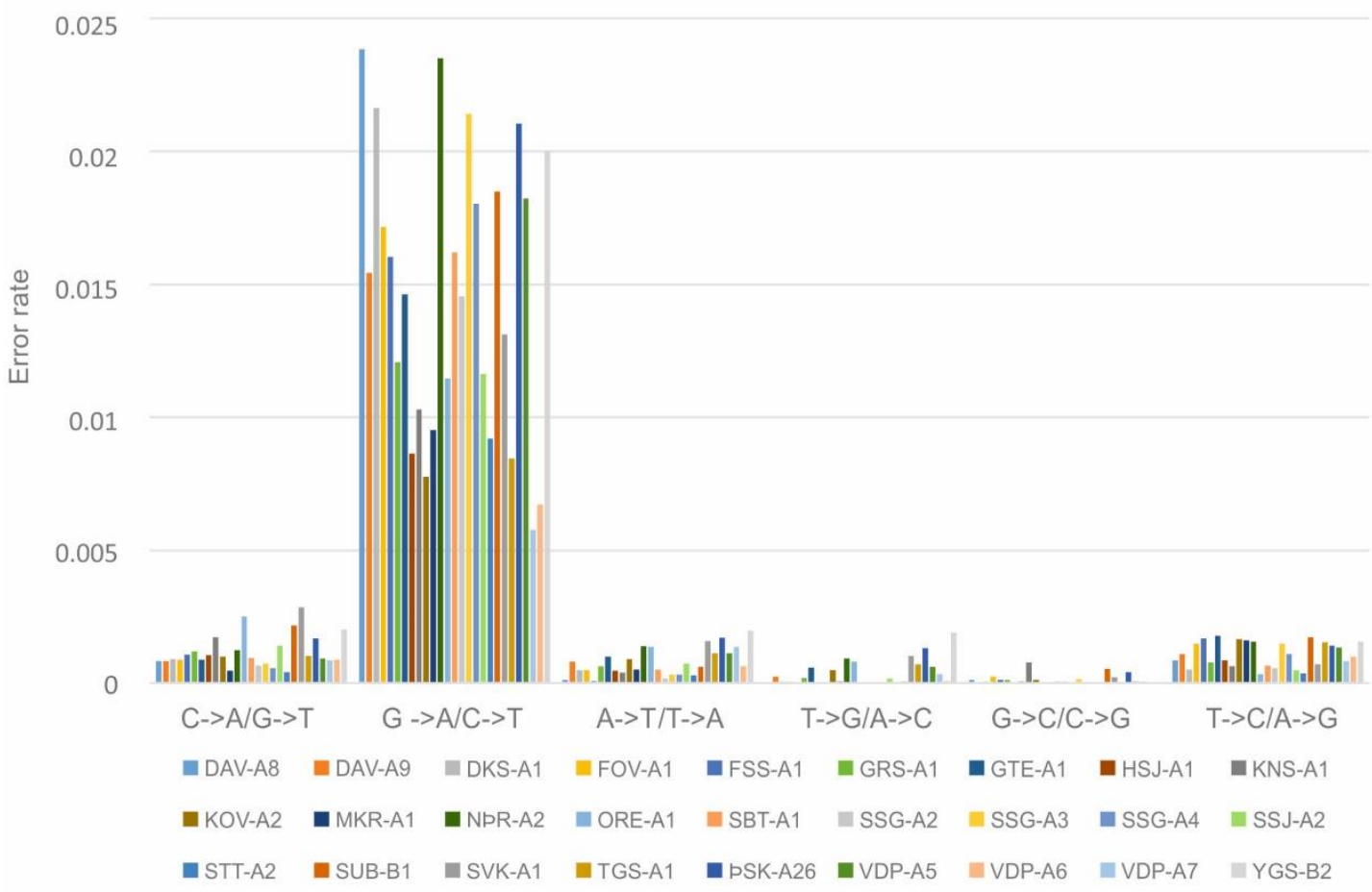

Fig. S1. Error rate estimates for each ancient sample used in this study. (A) Error rate per sample using an outgroup and high quality genome. (B) Type-specific error rate using an outgroup and high quality genome. 


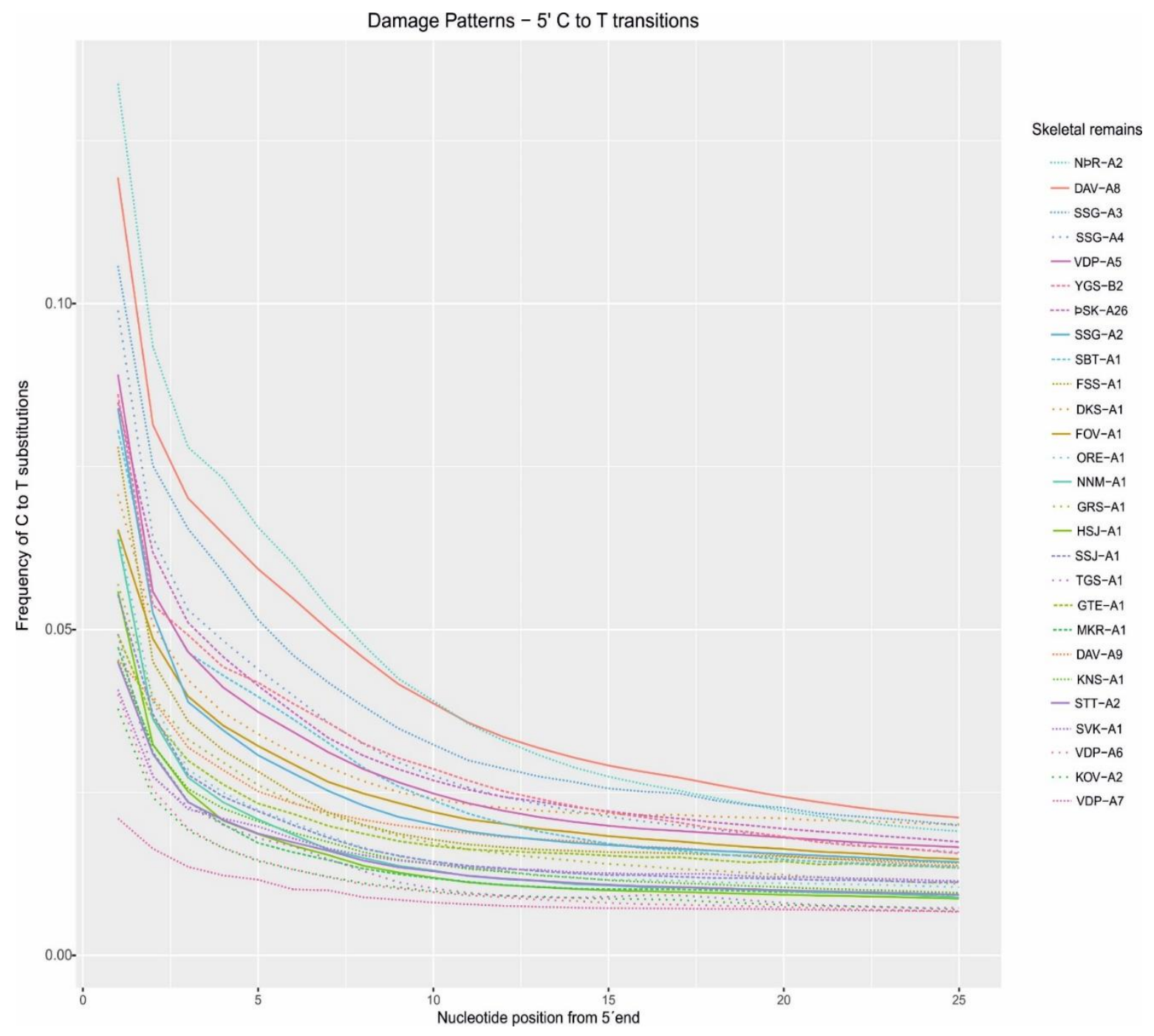

Fig. S2. Ancient DNA damage. aDNA damage parameters were estimated using the Bayesian approach implemented in mapDamage 2.0 (47). The line chart records the average C to $\mathrm{T}$ transitions for the first 25 bases at the $5^{\prime}$ end of reads. Samples are arranged in order of damage patterns at first position, from highest to lowest. 
$\mathbf{A}$

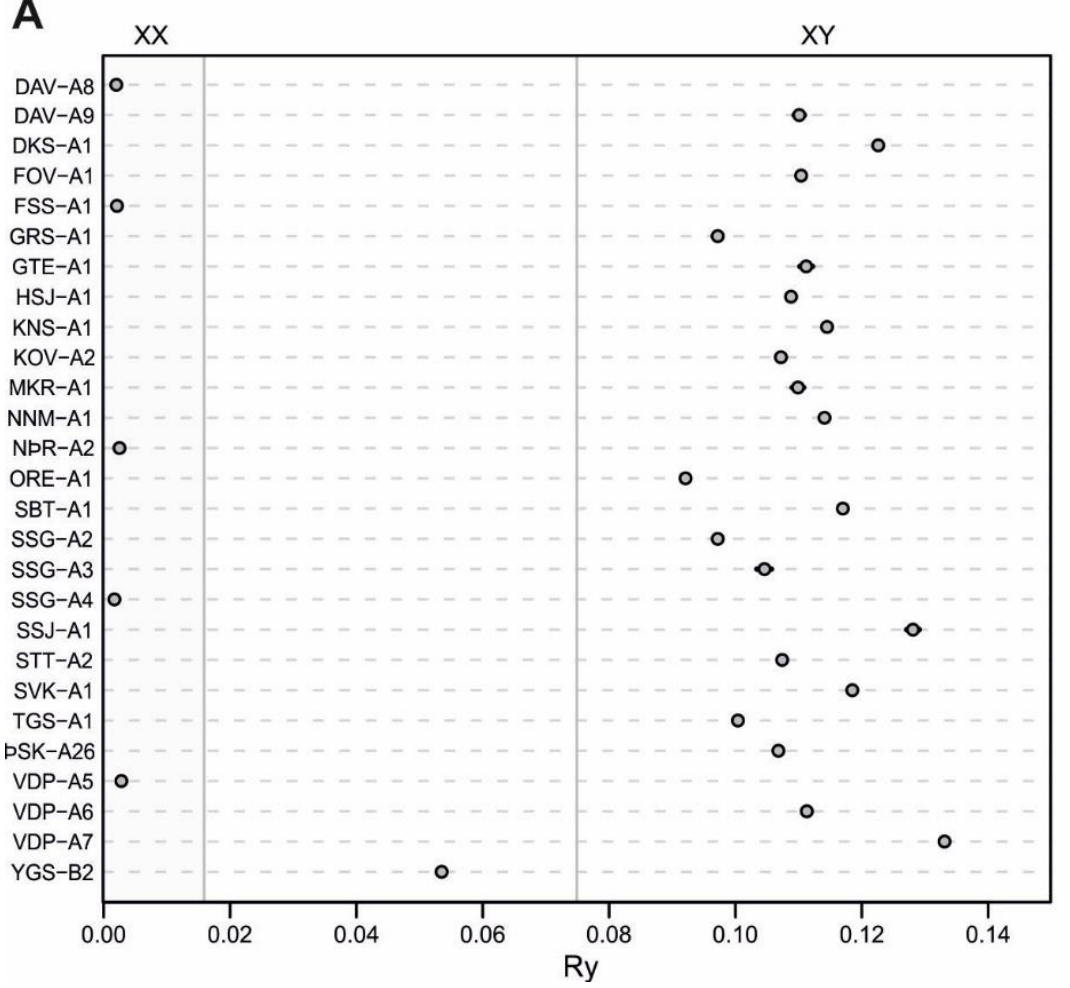

B

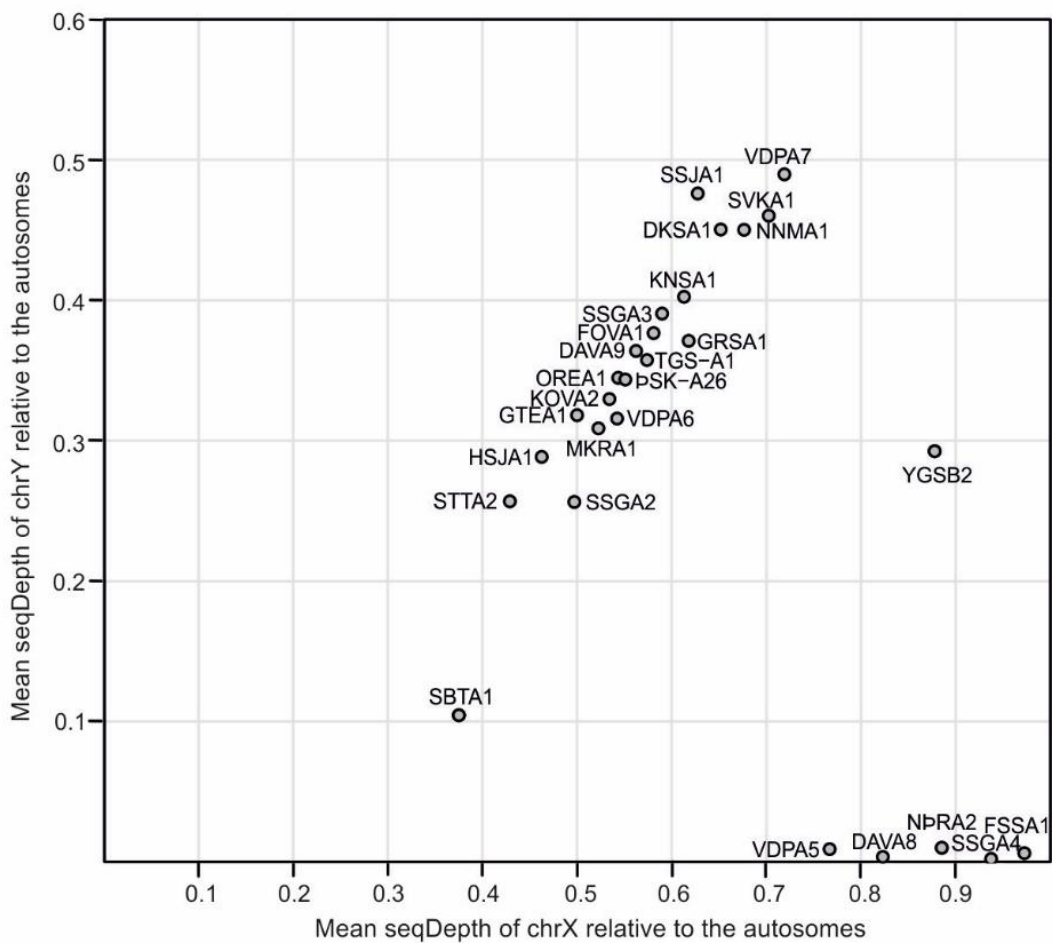

Fig. S3. Sex determination based on WGS data. (A) $R_{y}$ - ratio of the number of reads aligning to the Y chromosome compared to the number of reads mapping to both sex chromosomes. Only reads with mapping quality above 30 were considered. Error bars correspond to $95 \%$ CI.

Samples were classified as female when the upper bound of this CI was $<0.016$ (left vertical line), and classified as male when the lower bound was $>0.075$ (right vertical line). (B) Scatterplot showing the average sequence depth for X and Y chromosomes, scaled by the average autosomal sequence depth for each sample. For females, $\mathrm{X}$ chromosome coverage is expected to be similar to that of autosomes, whereas $\mathrm{Y}$ chromosome coverage should be minimal. For males, the coverage of both $\mathrm{X}$ and $\mathrm{Y}$ chromosomes should be half of the autosomes. Males and females, as defined by $R_{y}$, are clearly separated into distinct clusters, but YGS-B2 falls within the range of males for Y chromosome depth and within the range of females for $\mathrm{X}$ chromosome depth. 


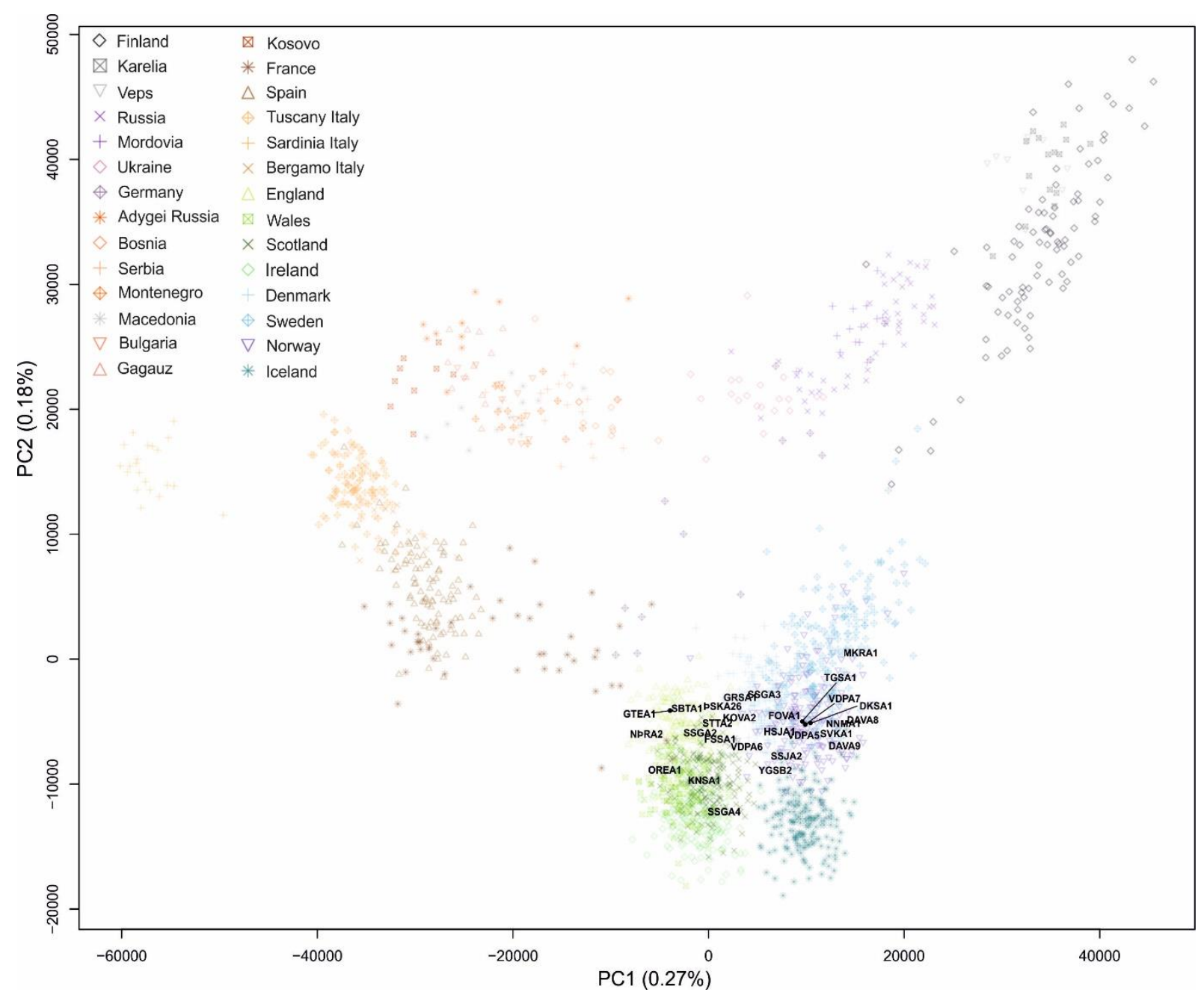

Fig. S4. PCA projection. Ancient Icelanders projected onto the first two eigenvectors of a PCA based on contemporary individuals from 28 European populations $(n=2,139)$ and 227,056 autosomal SNPs. Variance explained by the first two components is shown in brackets. 


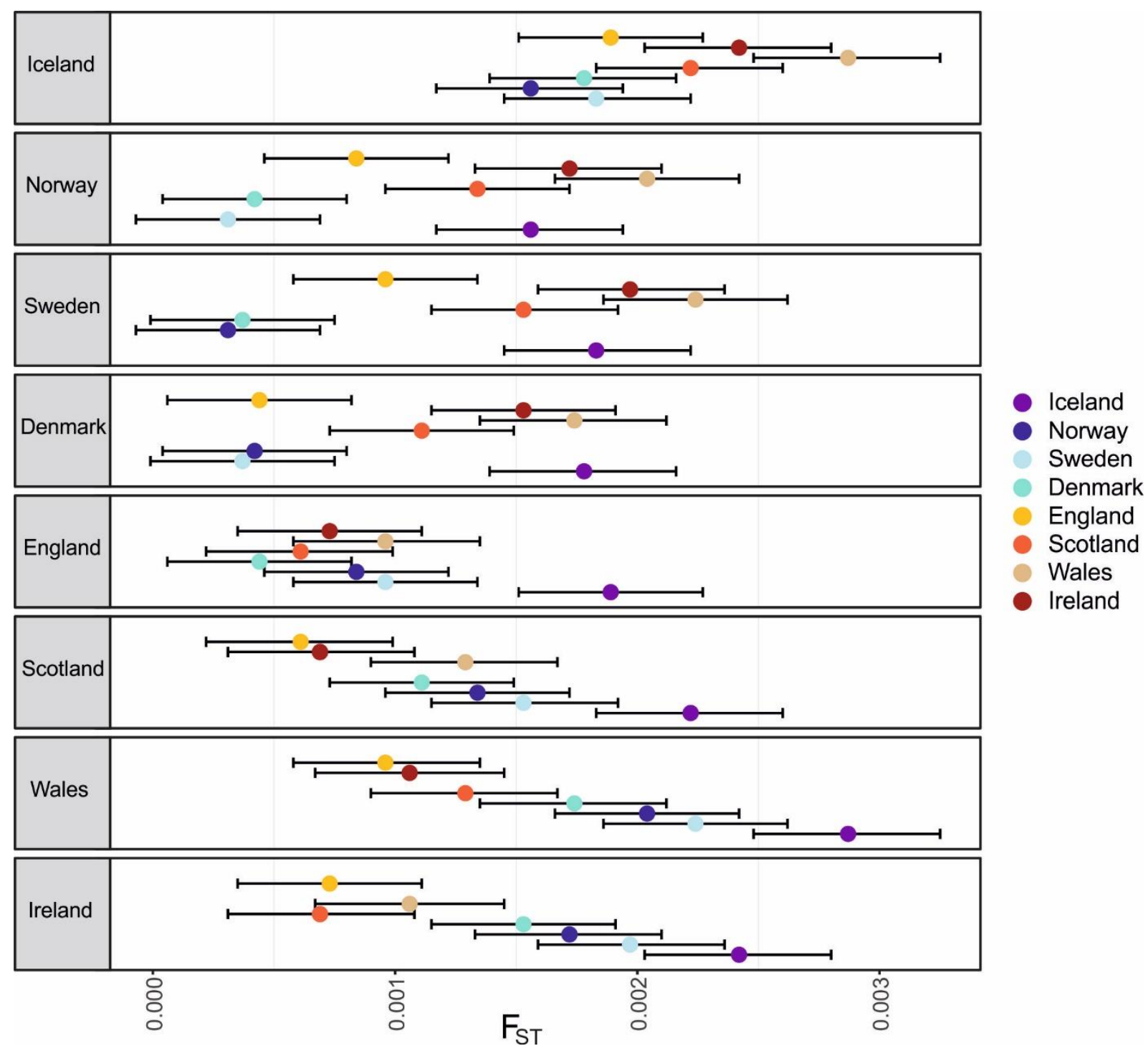

Fig. S5. The average Fst distances. Calculated between each pair of contemporary individuals from Iceland, Scandinavia and the British Isles using diploid genotypes from 404,066 autosomal SNPs. 


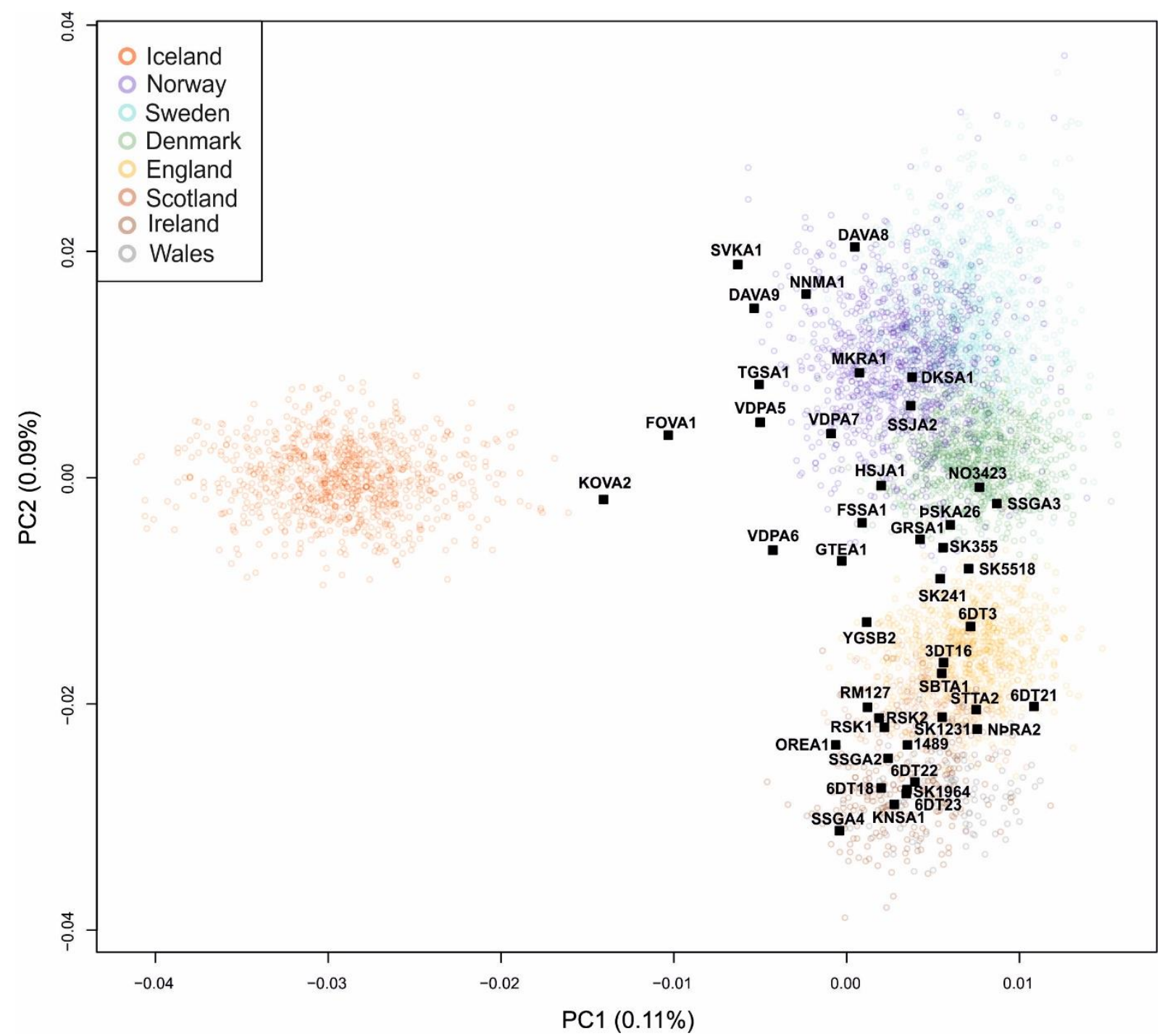

Fig. S6. Procrustes transformation. The coordinates for each ancient sample $(n=43)$ were transformed to match the first two eigenvectors based on contemporary individuals from Scandinavia $(n=3,118)$, the British Isles $(n=1,436)$ and Iceland $(n=916)$.Variance explained by the first two components is shown in brackets. 
A
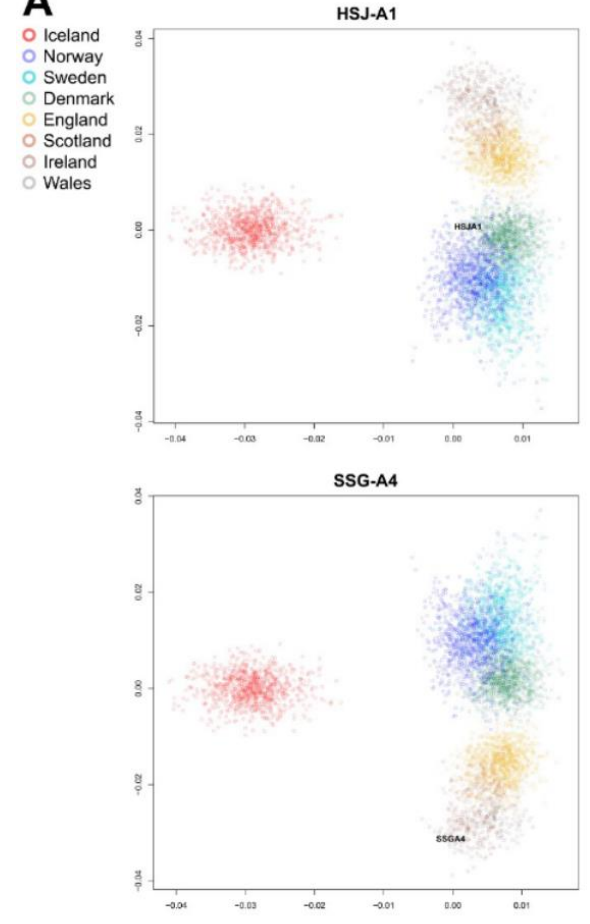

VDP-A5

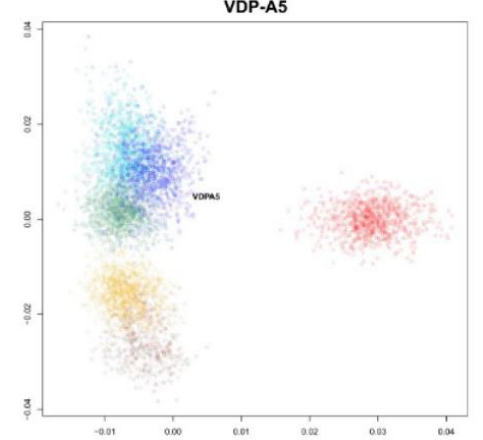

STT-A2

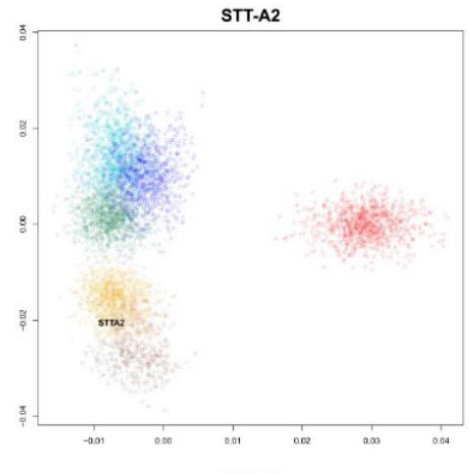

SBT-A1
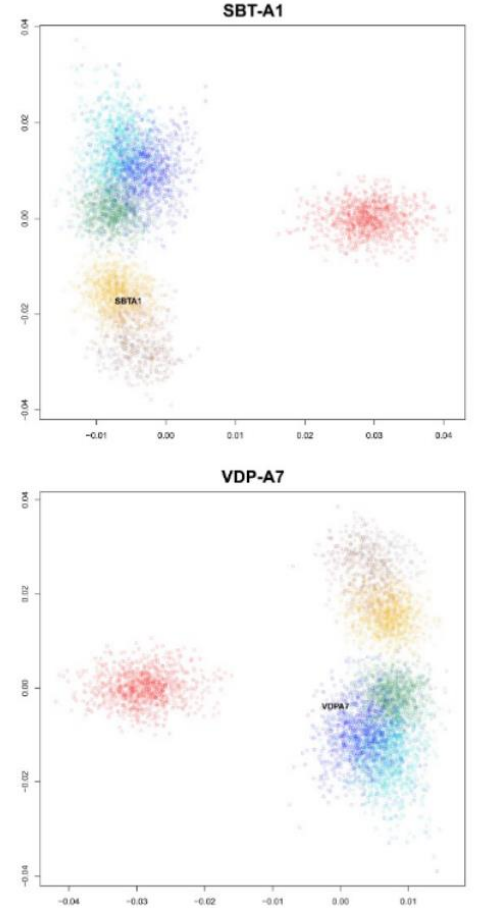

SSG-A2

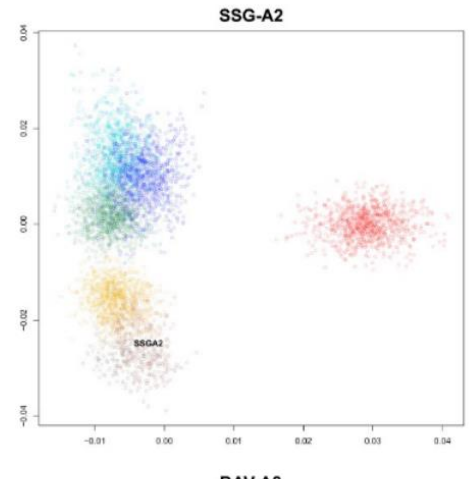

DAV-A8
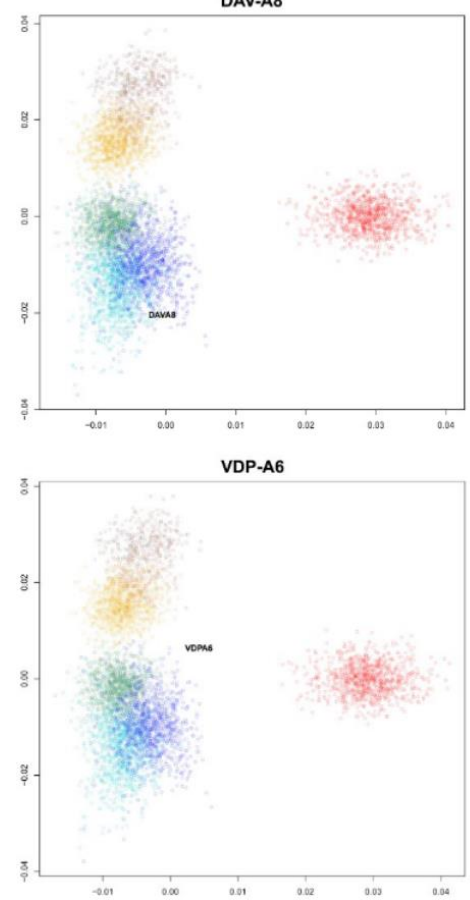


\section{B}

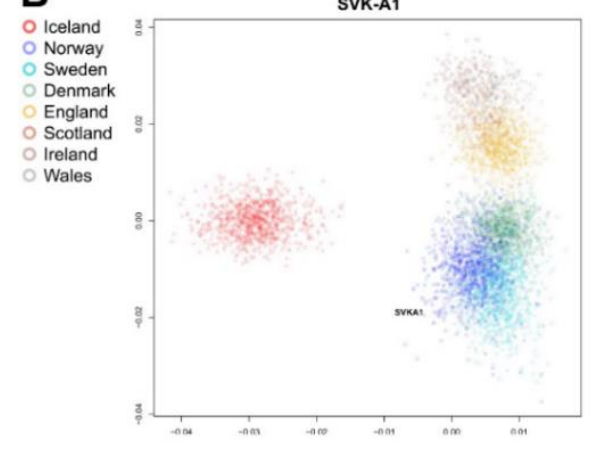

PSK-A26
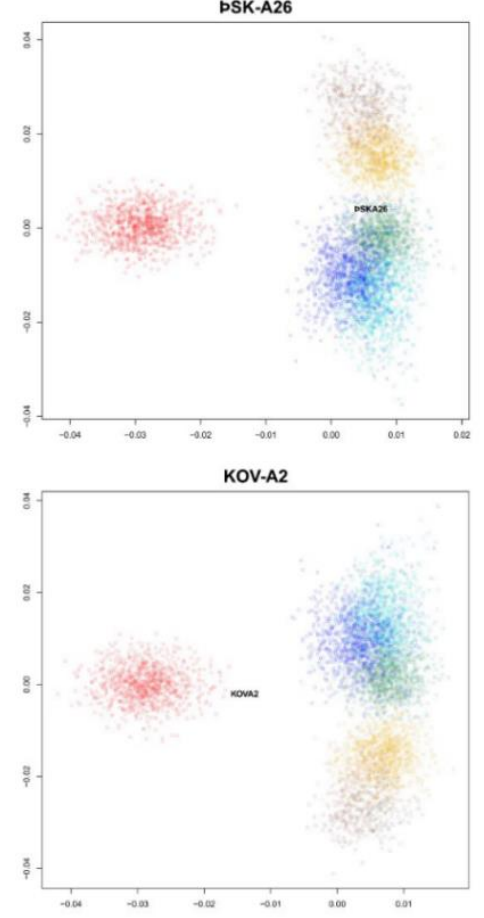

FSS-A1

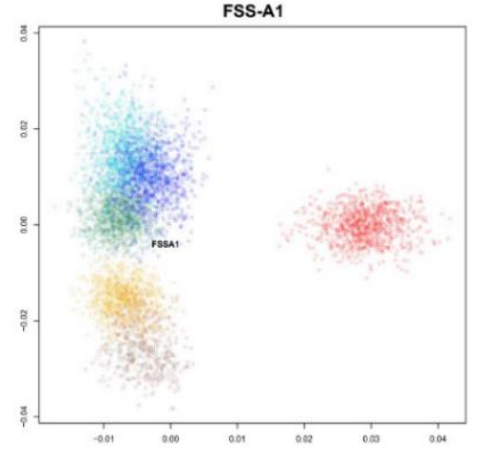

FOV-A1
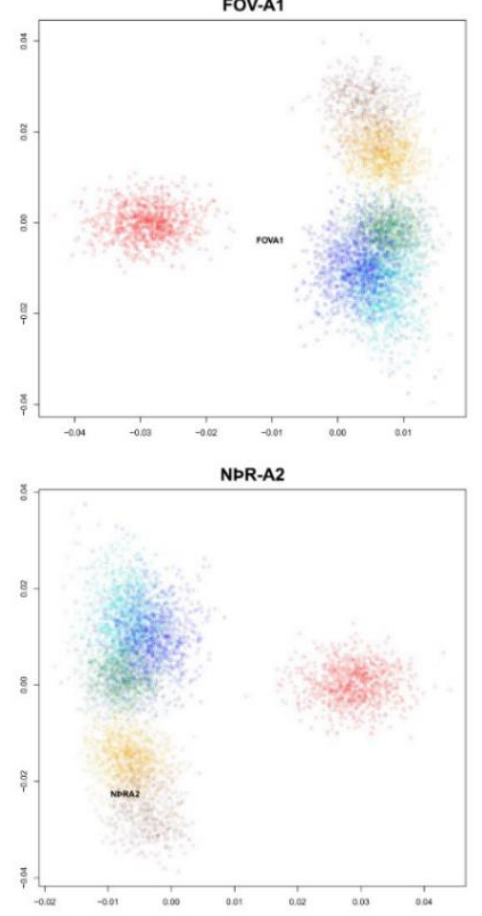

TGS-A1

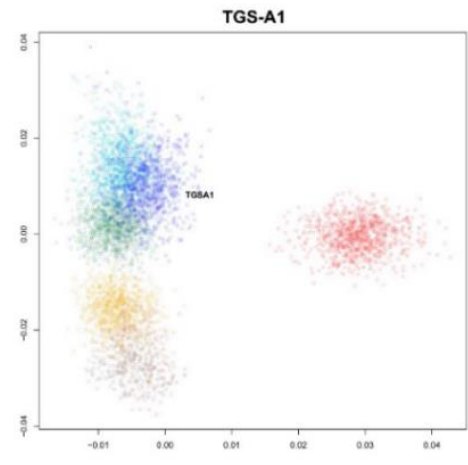

KNS-A1
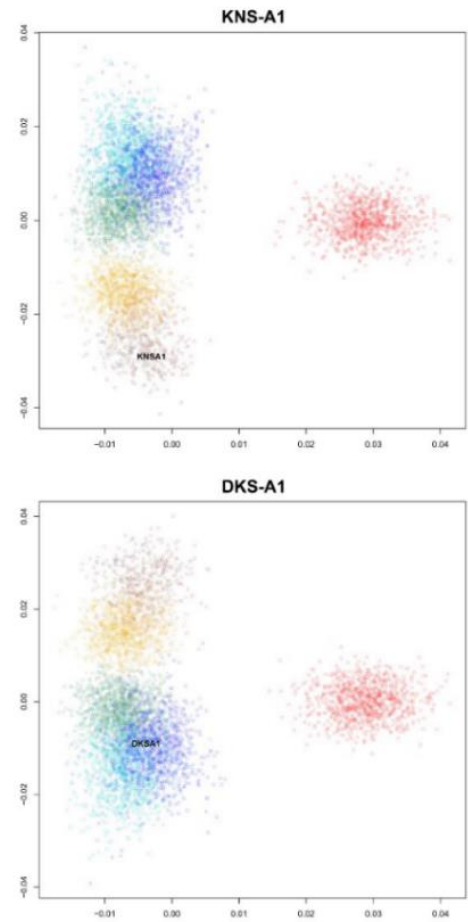

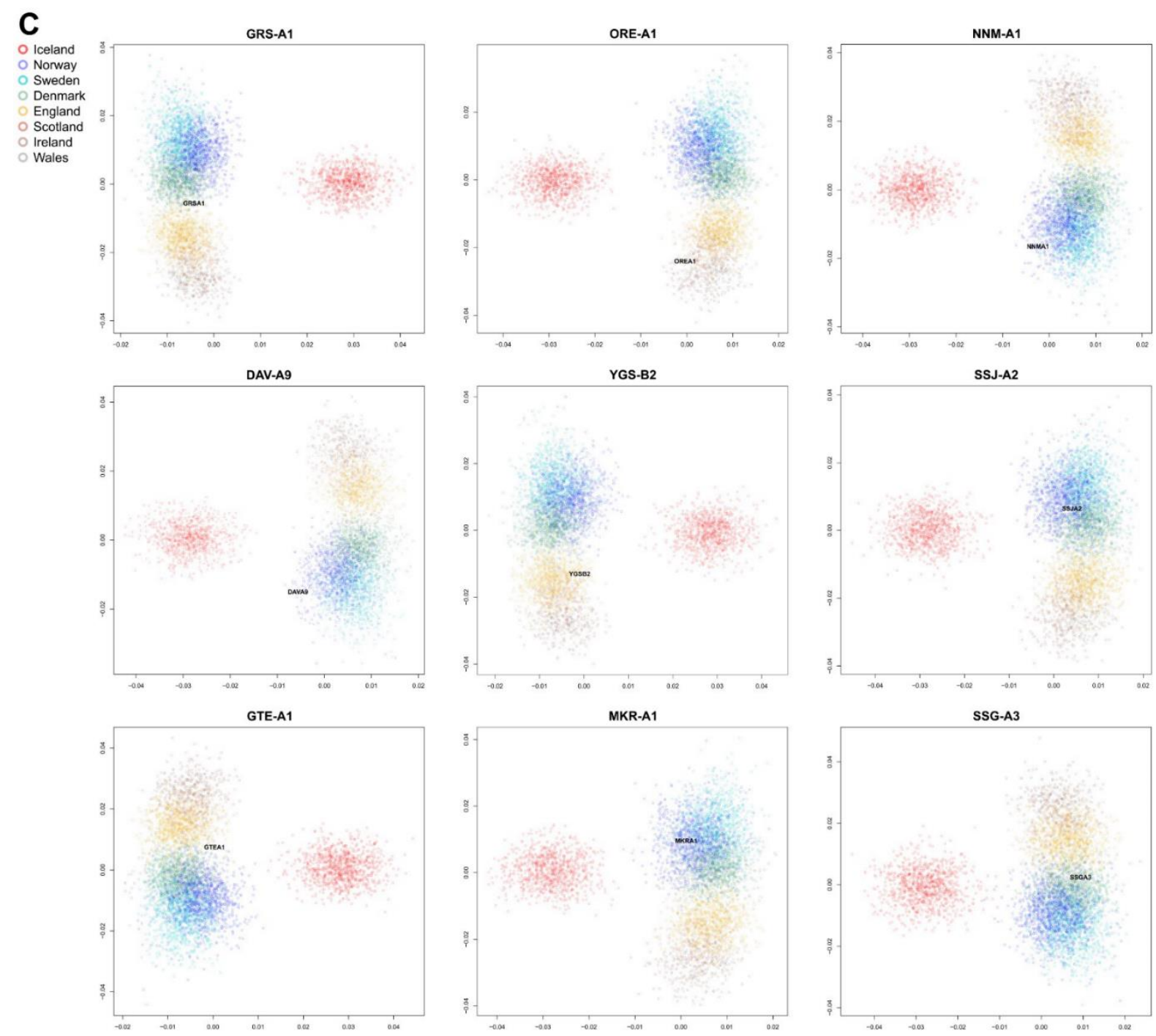

Fig. S7. PCAs of individual samples. Based on overlapping SNPs after merging each ancient individual with the North European reference data. Figures $(\mathbf{A}),(\mathbf{B})$ and $(\mathbf{C})$ are sorted by percentage of overlapping SNPs (see main Table 1), from highest to lowest. 
A

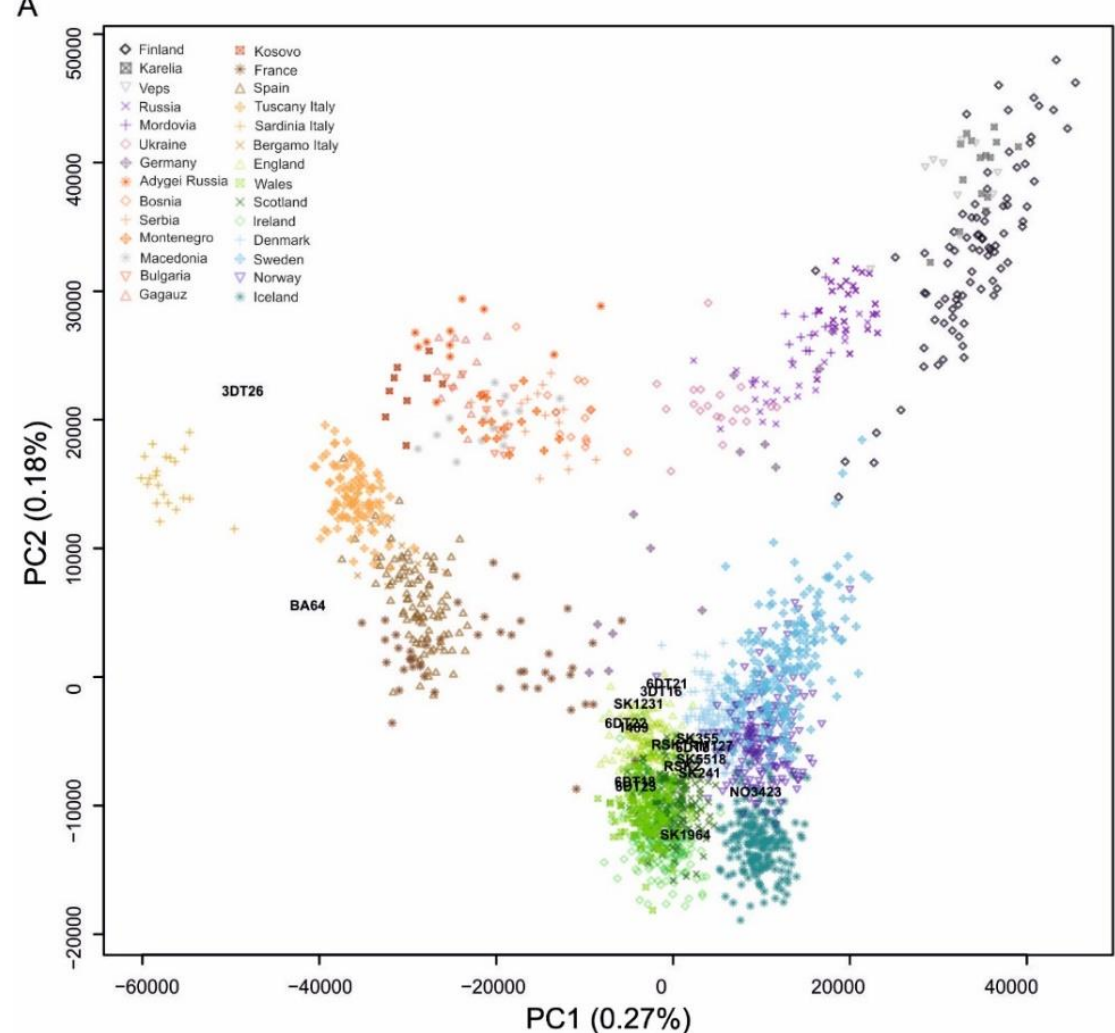

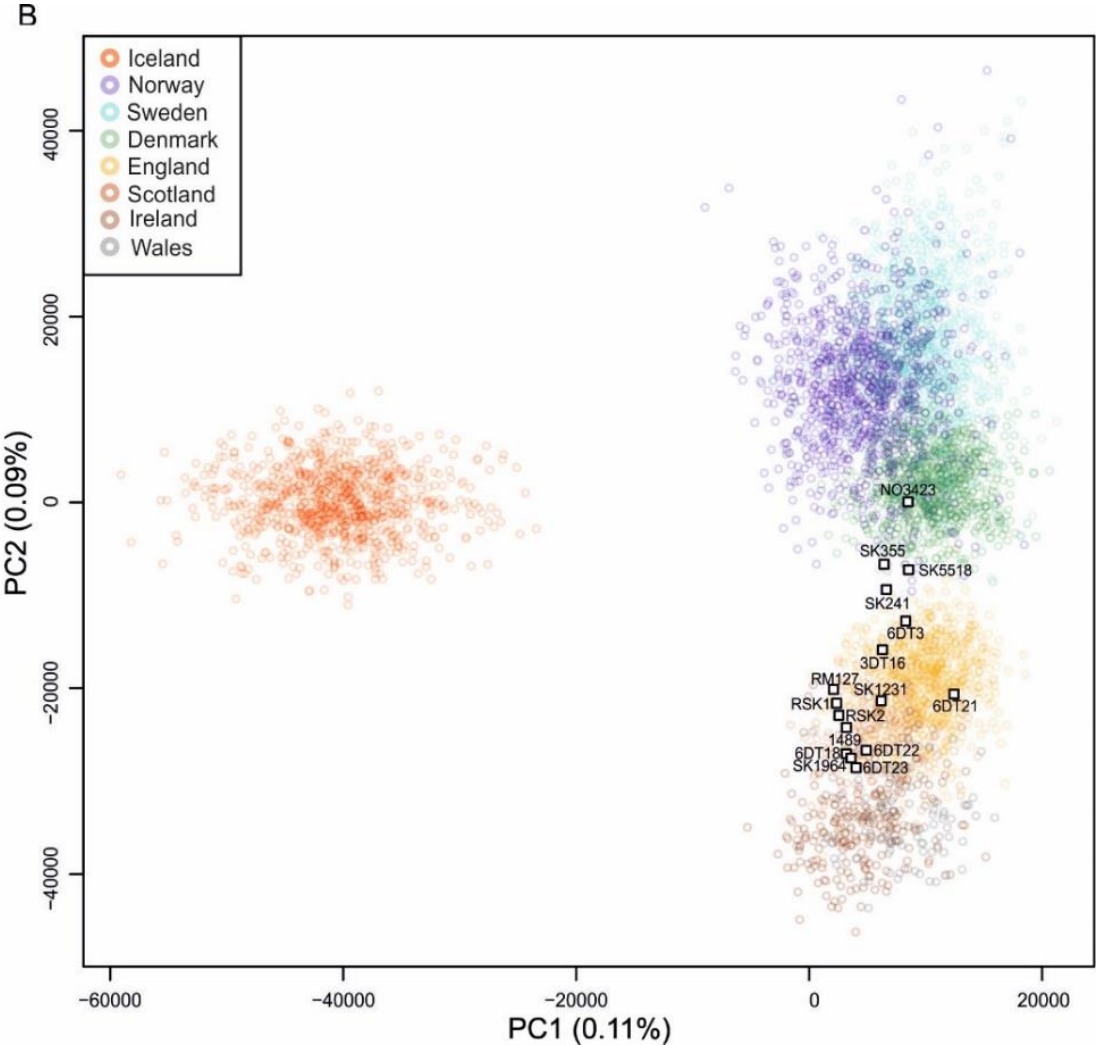

Fig. S8. PCAs showing the relationship between previously published ancient genomes from the British Isles and contemporary populations. (A) Ancient British and Irish genomes $(n=18)$ projected onto the first two eigenvectors of a PCA based on contemporary individuals from 28 European populations $(n=2,139)$ using diploid genotypes from 227,056 autosomal SNPs. (B) Ancient British and Irish genomes plotting within the Northern Europe cluster in Fig. S8A $(n=6)$ projected onto the first two eigenvectors of a PCA based on contemporary individuals from Scandinavia $(n=3,118)$, the British Isles $(n=1,436)$ and Iceland $(n=916)$ using diploid genotypes from 404,066 autosomal SNPs. 


\section{Supplementary tables}

Table S1. Overview of all ancient skeletal remains screened for this study.

\begin{tabular}{|c|c|c|c|c|c|c|c|c|c|c|c|c|}
\hline $\begin{array}{l}\text { Time } \\
\text { period }\end{array}$ & $\begin{array}{l}\text { Classification } \\
\text { based on } \\
{ }^{87} \mathrm{Sr} / 86 \mathrm{Sr} \text { value } \\
(3,4)\end{array}$ & $\begin{array}{l}\text { Sample } \\
\text { ID }\end{array}$ & $\begin{array}{l}\text { Grave } \\
\text { goods }\end{array}$ & $\begin{array}{l}\text { Archaeo- } \\
\text { logical date }\end{array}$ & ${ }^{14} \mathrm{C}$ date & $\begin{array}{l}\text { Typology } \\
\text { date }^{1}\end{array}$ & $\begin{array}{l}\text { Archaeological } \\
\text { sex }^{2}\end{array}$ & $\begin{array}{r}\text { Age or } \\
\text { age } \\
\text { class }^{2}\end{array}$ & $\mathbf{N}+$ & $Y_{\ddagger}$ & Site & Region \\
\hline \multirow{17}{*}{$\begin{array}{l}\text { Pre- } \\
\text { Christian }\end{array}$} & \multirow[t]{9}{*}{ Migrant } & $\mathrm{DAV}-\mathrm{A} 7^{*}$ & yes & $<1000$ & $<1050$ & $900-1000$ & Male & $<35$ & 13 & 1909 & Dalvík (Brimnes) & North \\
\hline & & DAV-A8 & yes & $<1000$ & $<1050$ & $900-1000$ & Female? & $25-34$ & 13 & 1909 & Dalvík (Brimnes) & North \\
\hline & & DAV-A9 & yes & $<1000$ & $980-1020$ & $900-1000$ & Female? & $18-25$ & 13 & 1909 & Dalvík (Brimnes) & North \\
\hline & & HBS-A6* & yes & $<1000$ & NA & $900-1000$ & Male & $35-45$ & $7-8$ & 1947 & Hafurbjarnarstaðir & South \\
\hline & & KRE-A1* & yes & $<1000$ & NA & $900-1000$ & Male & $35-45$ & 2 & 1900 & Kroppur & North \\
\hline & & SSG-A1* & yes & $<1000$ & $980-1020$ & $850-1000$ & Male & $45+$ & 4 & 1947 & Sílastaðir & North \\
\hline & & SSG-A2 & yes & $<1000$ & NA & $850-1000$ & Male & $45+$ & 4 & 1947 & Sílastaðir & North \\
\hline & & SSG-A3 & yes & $<1000$ & NA & $850-1000$ & Male & $35-45$ & 4 & 1947 & Sílastaðir & North \\
\hline & & SSG-A4 & yes & $<1000$ & NA & $850-1000$ & Female? & $35-45$ & 4 & 1947 & Sílastaðir & North \\
\hline & \multirow[t]{8}{*}{ Non-migrant } & DKS-A1 & yes & $<1000$ & NA & $850-1000$ & Unknown & $18-25$ & 1 & 1962 & Öndverðarnes & West \\
\hline & & EIM-A1* & yes & $<1000$ & NA & $900-1000$ & Female & $25-35$ & 1 & 1979 & Einholt & East \\
\hline & & GRS-A1 & yes & $<1000$ & $<1050$ & NA & Male & $35-45$ & 3 & 1937 & Grímsstaðir & North \\
\hline & & GTE-A1 & yes & $<1000$ & NA & NA & Male & $18-25$ & 1 & 1957 & Gilsárteigur & East \\
\hline & & HSJ-A1 & yes & $<1000$ & NA & NA & Male & $35-45$ & 4 & 1996 & Hrólfsstaðir & East \\
\hline & & KNS-A1 & yes & $<1000$ & NA & $950-1050$ & Male & $35-45$ & 1 & 1932 & Karlsnes & South \\
\hline & & MKR-A1 & no & $<1000$ & $<1050$ & NA & Male & $35-45$ & 1 & 1989 & Víđar (Másvatn) & North \\
\hline & & NNM-A1 & no & $<1000$ & NA & NA & Unknown & Adult & 1 & 1981 & Njarðvík & East \\
\hline
\end{tabular}




\begin{tabular}{|c|c|c|c|c|c|c|c|c|c|c|c|c|}
\hline & & ORE-A1 & yes & $<1000$ & NA & $900-1000$ & Male & $45+$ & 1 & 1966 & Ormsstaðir & East \\
\hline & & SBT-A1 & yes & $<1000$ & NA & NA & Male & $45+$ & 1 & 1954 & Smyrlaberg & North \\
\hline & & SSJ-A2 & yes & $<1000$ & NA & $850-1000$ & Male & $35-45$ & 2 & 1949 & Surtsstaðir & East \\
\hline & & STT-A2 & yes & $<1000$ & $975-1015$ & $900-1000$ & Male & $45+$ & 1 & 1952 & Straumur & East \\
\hline & & SVK-A1 & yes & $<1000$ & $<1050$ & NA & Male & $35-45$ & 1 & 1961 & Svínadalur & North \\
\hline & & VDP-A3* & yes & $<1000$ & NA & $850-1050$ & Male & $18-25$ & 7 & 1964 & Vatnsdalur & West \\
\hline & & VDP-A5 & yes & $<1000$ & NA & $850-1050$ & Female & $35-45$ & 7 & 1964 & Vatnsdalur & West \\
\hline & & VDP-A6 & yes & $<1000$ & NA & $850-1050$ & Male & $25-35$ & 7 & 1964 & Vatnsdalur & West \\
\hline & & VDP-A7 & yes & $<1000$ & NA & $850-1050$ & Male & $35-45$ & 7 & 1964 & Vatnsdalur & West \\
\hline & Not available & FSS-A1 & no & $<1000$ & NA & NA & Female & $35-45$ & 1 & 1960 & Fremri-Svartárdalur & North \\
\hline & & GRF-A1* & yes & $<1000$ & $723-1122$ & NA & Unknown & $7-12$ & 3 & 1962 & Grímsstaðir 'the old' & North \\
\hline & & NPR-A2 & no & $<1000$ & NA & NA & Female? & Adult? & 2 & 1952 & Neðri-Pverá & South \\
\hline & & SUB-A1* & no & $<1000$ & $683-970$ & NA & Male & Adult & 2 & 1947 & Suðurárbotnar & North \\
\hline & & YGS-B2 & yes & $<1000$ & NA & NA & Unknown & $7-12$ & 9 & 1954 & Ytra-Garðshorn & North \\
\hline $\begin{array}{l}\text { Early } \\
\text { Christian }\end{array}$ & Non-migrant & PSK-A26 & NA & $1000-1104$ & 1120 & NA & Male & Adult & NA & 1939 & Skeljastað̄ir & South \\
\hline $\begin{array}{l}\text { 17th } \\
\text { Century }\end{array}$ & Not available & KOV-A2 & NA & b. 1678 & NA & NA & Male & 26 & 2 & 1988 & Kópavogur & West \\
\hline \multirow[t]{2}{*}{ Unknown } & & FOV-A1 & no & Unknown & NA & NA & Male & Adult & 1 & 1929 & Fossvellir & East \\
\hline & & TGS-A1 & no & Unknown & NA & NA & Male & Adult & 1 & 1981 & Tunga & North \\
\hline
\end{tabular}

Samples marked with an asterisk symbol (*) were ultimately excluded from further analysis. $\dagger$ Number of remains found at site. $\$$ Year of exhumation. ${ }^{1}(11,12)$ ${ }^{2}$ (69) 
Table S2. Overview of extractions, library builds and sequencing done on ancient genomes analysed in this study. We constructed 61 libraries from 50 DNA extractions of 35 ancient Icelandic skeletal remains. Library names indicate which DNA extraction method was used: phenol/chloroform purification method $(\mathrm{P})$ or the modified silica extraction method (S).

\begin{tabular}{|c|c|c|c|}
\hline \multirow[t]{2}{*}{ Sample } & Library & $\begin{array}{r}\text { Pre WGE (no. of } \\
\text { HiSeq lanes) }\end{array}$ & $\begin{array}{l}\text { Post WGE (no. } \\
\text { of HiSeq lanes) }\end{array}$ \\
\hline & & \multicolumn{2}{|c|}{ MiSeq - endogenous (endo) \% } \\
\hline DAV-A8 & 25_P1 & 59.16 & $60.46(1)$ \\
\hline DAV-A8 & 25_S1 & 29.72 & $51.14(2)$ \\
\hline DAV-A9 & 26_P1 & 2.04 & $30.25(2)$ \\
\hline DAV-A9 & 26_P2 & 2.07 & $21.77(1)$ \\
\hline DKS-A1 & 27_P1 & NA & $16.36(1)$ \\
\hline DKS-A1 & 27_s1 & 1.64 & $22.99(2)$ \\
\hline DKS-A1 & $27-1$ & $0.22(1)$ & NÁ \\
\hline FOV-A1 & 32_P1 & 7.31 & $23.51(1)$ \\
\hline FOV-A1 & 32_P2 & 5.47 & $33.78(1)$ \\
\hline FSS-A1 & 34_P1 & 40.94 & $58.22(1)$ \\
\hline GRS-A1 & $38 \mathrm{P} 1$ & 8.43 & $31.83(2)$ \\
\hline GRS-A1 & 38_P2 & 5.86 & $31.1(1)$ \\
\hline GTE-A1 & 44_P1 & 6.62 & $32.65(2)$ \\
\hline HSJ-A1 & $2 \_\bar{P} 1$ & 29.08 & $50.6(4)$ \\
\hline HSJ-A1 & 2 & 33.04 & $53.2(2)$ \\
\hline HSJ-A1 & 39 & 35.26 & $47.37(2)$ \\
\hline HSJ-A1 & 39 s1 & 60.14 & $50.26(4)$ \\
\hline KNS-A1 & 52_S1 & 6.01 & $32.95(2)$ \\
\hline KOV-A2 & 3_ $\mathrm{P} 1$ & 8.67 & $26(1)$ \\
\hline MKR-A1 & 49̄_P1 & 4.44 & 27.52 (1) \\
\hline NNM-A1 & 50_P1 & 6.72 & 32.89 (1) \\
\hline NPR-A2 & $63^{-} \mathrm{P} 1$ & 13.83 & 29.1 (1) \\
\hline ORE-A1 & 56_S1 & 22.43 & 28.57 (1) \\
\hline SBT-A1 & 66_P1 & 18.11 & 62.03 (1) \\
\hline SBT-A1 & 66_S1 & $54.09(2)$ & $64.15(2)$ \\
\hline SSG-A2 & 67_P2 & $65.51(4)$ & 37.07 \\
\hline SSG-A2 & 67_s1 & 29.29 & $50.45(4)$ \\
\hline SSG-A3 & 58_P2 & 2.7 & $21.32(1)$ \\
\hline SSG-A4 & 63_P1 & 44.82 & $57.3(2)$ \\
\hline SSG-A4 & 63_P2 & 38.47 & $53.54(2)$ \\
\hline SSG-A4 & 63_S1 & 31.35 & $56.92(2)$ \\
\hline SSJ-A2 & 77_s1 & 4.41 & 36.45 (1) \\
\hline STT-A2 & 74_P1 & 23.46 & 40.44 (1) \\
\hline STT-A2 & 74 S1 & 43.8 & $55.96(4)$ \\
\hline SVK-A1 & 70 S1 & 6.24 & 32.5 (1) \\
\hline TGS-A1 & 8_P1 & NA & 61.88 (1) \\
\hline VDP-A5 & $9 \overline{7}+\mathrm{P} 1$ & 30.21 & $40.94(5)$ \\
\hline VDP-A5 & 97_s1 & 11.24 & 49.49 (1) \\
\hline VDP-A6 & $10 \overline{1} \mathrm{P} 1$ & 1.99 & 26.27 (1) \\
\hline VDP-A6 & 101_S1 & 14.37 & 36.39 (2) \\
\hline VDP-A7 & 94_P1 & 8.81 & $31.85(1)$ \\
\hline VDP-A7 & 94_S1 & 10.07 & $63.44(2)$ \\
\hline YGS-B2 & 92_P1 & NA & 41.02 (1) \\
\hline YGS-B2 & $92 \_1$ & $0.36(1)$ & NA \\
\hline PSK-A26 & $9 \overline{\mathrm{P}} 1$ & 15.4 & $43.49(2)$ \\
\hline \multicolumn{4}{|c|}{ Libraries excluded based on Bioanalyzer results } \\
\hline DAV-A7 & 24_S1 & NA & NA \\
\hline HBS-A6 * & 42_P1 & NA & NA \\
\hline KRE-A1 * & 53_P1 & NA & NA \\
\hline SSG-A2 & 67_P1 & NA & NA \\
\hline SSG-A3 & $58 \mathrm{P} 1$ & NA & NA \\
\hline VDP-A3 * & $88 \mathrm{P} 1$ & NA & NA \\
\hline \multicolumn{4}{|c|}{ Libraries excluded based on MiSeq results (endo $<15 \%$ ) } \\
\hline DAV-A7 * & 24_P1 & 1.26 & 12.49 \\
\hline DAV-A7 * & 24_P2 & 1.81 & WGE failed \\
\hline
\end{tabular}




\begin{tabular}{lccr} 
DKS-A1 & 27_P2 & 0.96 & NA \\
GRF-A1 * & 55_S1 & 6.96 & WGE failed \\
KNS-A1 & 52_P1 & 0.85 & NA \\
MKR-A1 & 49_P2 & 2.92 & WGE failed \\
SSG-A1 * & 68_P1 & NA & 14.24 \\
\hline \multicolumn{4}{l}{ Libraries excluded based on contamination results (Table S4) } \\
\hline GTE-A1 & 44_S1 & 6.5 & $35.42(2)$ \\
SUB-B1 * & 100_P1 & 35.7 & $47.76(1)$ \\
\hline \multicolumn{4}{l}{ Libraries excluded based on sequencing depth/coverage (Table S3) }
\end{tabular}

EIM-A1 * 28 P1 $3.29 \quad 19.47$ (1)

Samples marked with an asterisk symbol $(*)$ were ultimately excluded from further analysis. 
Table S3. Details and statistics for all libraries $(\boldsymbol{n}=49)$ sequenced on the Illumina HiSeq platform. Trimmed reads is the total number of reads passing quality and length filtering. Mapped reads is the number of reads mapping to the human genome. Endo \% is the percentage of reads mapped to the human genome. Endo \% without dup is the percentage of reads mapped to the human genome after removing duplicate reads. Dup $\%$ is the percentage of duplicates reads after mapping to the human genome. Final reads indicate the number of reads mapped to the human genome without duplicates. Read length indicates the average read length of final reads. DoC $(\mathbf{X})$ indicates the mean autosomal depth of coverage. Auto. Cov. shows the fraction of the autosomal genome that is covered by at least one read.

\begin{tabular}{|c|c|c|c|c|c|c|c|c|c|c|c|c|}
\hline Sample & $\begin{array}{l}\text { Library } \\
\text { ID }\end{array}$ & WGE & $\begin{array}{r}\text { Trimmed } \\
\text { reads }\end{array}$ & $\begin{array}{r}\text { Mapped } \\
\text { reads }\end{array}$ & Endo \% & $\begin{array}{r}\text { Trimmed } \\
\text { reads }\end{array}$ & Final reads & $\begin{array}{r}\text { Endo \% } \\
\text { without } \\
\text { dup } \\
\end{array}$ & Dup \% & $\begin{array}{r}\text { Read } \\
\text { length }\end{array}$ & DoC (X) & $\begin{array}{l}\text { Auto. } \\
\text { Cov. }\end{array}$ \\
\hline DAV-A8 & 25_P1 & Yes & 269547770 & 201283564 & 74.67 & 197078840 & 128814634 & 65.36 & 36 & 80 & 1.1 & 0.76 \\
\hline DAV-A8 & 25_S1 & Yes & 261186173 & 159838243 & 61.2 & 214636371 & 113288441 & 52.78 & 29.1 & 77 & 1.17 & 0.78 \\
\hline DAV-A8 & 25_S1 & Yes & 297520712 & 185583494 & 62.38 & 239432152 & 127494934 & 53.25 & 31.3 & 77 & 1.22 & 0.81 \\
\hline DAV-A9 & 26_P1 & Yes & 282633784 & 133832869 & 47.35 & 170246657 & 21445742 & 12.6 & 84 & 89 & 0.21 & 0.14 \\
\hline DAV-A9 & 26_P2 & Yes & 305892099 & 95050113 & 31.07 & 233805417 & 22963431 & 9.82 & 75.8 & 79 & 0.21 & 0.15 \\
\hline DAV-A9 & 26_P1 & Yes & 281111011 & 98803057 & 35.15 & 209527794 & 27219840 & 12.99 & 72.5 & 91 & 0.39 & 0.24 \\
\hline DKS-A1 & $27 \_1$ & No & 363194526 & 2027247 & 0.56 & 362707894 & 1540615 & 0.42 & 24 & 104 & 0.03 & 0.02 \\
\hline DKS-A1 & 27_P1 & Yes & 229253823 & 70640728 & 30.81 & 167944567 & 9331472 & 5.56 & 86.8 & 99 & 0.1 & 0.06 \\
\hline DKS-A1 & 27_S1 & Yes & 309244488 & 104089571 & 33.66 & 238452900 & 33297983 & 13.96 & 68 & 121 & 0.59 & 0.38 \\
\hline DKS-A1 & 27_S1 & Yes & 295343683 & 98850875 & 33.47 & 235686371 & 39193563 & 16.63 & 60 & 126 & 0.59 & 0.38 \\
\hline EIM-A1 & 28_P1* & Yes & 287039389 & 110406182 & 38.46 & 192088689 & 15455482 & 8.05 & 86 & 92 & 0.12 & 0.08 \\
\hline FOV-A1 & 32_P2 & Yes & 266981327 & 115005525 & 43.08 & 190930150 & 38954348 & 20.4 & 66.1 & 80 & 0.4 & 0.3 \\
\hline FOV-A1 & 32_P1 & Yes & 288740067 & 95669302 & 33.13 & 230146760 & 37075995 & 16.11 & 61.2 & 87 & 0.58 & 0.38 \\
\hline FSS-A1 & 34_P1 & Yes & 262581240 & 187568997 & 71.43 & 163251215 & 88238972 & 54.05 & 53 & 76 & 0.94 & 0.66 \\
\hline GRS-A1 & 38_P1 & Yes & 168873197 & 71706374 & 42.46 & 118639923 & 21473100 & 18.1 & 70.1 & 69 & 0.3 & 0.19 \\
\hline GRS-A1 & 38_P1 & Yes & 262428188 & 110482391 & 42.1 & 180829038 & 28883241 & 15.97 & 73.9 & 69 & 0.31 & 0.2 \\
\hline GRS-A1 & 38_P2 & Yes & 296394594 & 125513294 & 42.35 & 214698912 & 43817612 & 20.41 & 65.1 & 83 & 0.47 & 0.35 \\
\hline GTE-A1 & 44_P1 & Yes & 203843887 & 110783054 & 54.35 & 111842242 & 18781409 & 16.79 & 83 & 94 & 0.31 & 0.19 \\
\hline GTE-A1 & 44_P1 & Yes & 289159138 & 154556495 & 53.45 & 158926635 & 24323992 & 15.31 & 84.3 & 95 & 0.32 & 0.2 \\
\hline GTE-A1 & 44_S1* & Yes & 236774327 & 127186947 & 53.72 & 176271023 & 66683643 & 37.83 & 47.6 & 114 & 0.96 & 0.66 \\
\hline GTE-A1 & 44_S1* & Yes & 283426244 & 153019255 & 53.99 & 201043785 & 70636796 & 35.14 & 53.8 & 109 & 1.01 & 0.69 \\
\hline HSJ-A1 & 2_P2 & Yes & 251817854 & 168561801 & 66.94 & 197083791 & 113827738 & 57.76 & 32.5 & 104 & 0.95 & 0.73 \\
\hline
\end{tabular}




\begin{tabular}{|c|c|c|c|c|c|c|c|c|c|c|c|c|}
\hline HSJ-A1 & 2_P2 & Yes & 302593056 & 201657118 & 66.64 & 224160436 & 123224498 & 54.97 & 38.9 & 100 & 1.01 & 0.76 \\
\hline HSJ-A1 & 39_P1 & Yes & 226083722 & 143683836 & 63.55 & 175506146 & 93106260 & 53.05 & 35.2 & 102 & 1.39 & 0.85 \\
\hline HSJ-A1 & 39_P1 & Yes & 226874875 & 143799561 & 63.38 & 176063126 & 92987812 & 52.82 & 35.3 & 102 & 1.39 & 0.85 \\
\hline HSJ-A1 & 2_P1 & Yes & 262411059 & 172156230 & 65.61 & 206666814 & 116411985 & 56.33 & 32.4 & 113 & 1.5 & 0.91 \\
\hline HSJ-A1 & 2_P1 & Yes & 265893809 & 173936214 & 65.42 & 209391653 & 117434058 & 56.08 & 32.5 & 113 & 1.86 & 0.91 \\
\hline HSJ-A1 & 2_P1 & Yes & 287039398 & 188900584 & 65.81 & 212725934 & 114587120 & 53.87 & 39.3 & 108 & 2.7 & 0.92 \\
\hline HSJ-A1 & 39_S1 & Yes & 258276576 & 195101589 & 75.54 & 230631102 & 167456115 & 72.61 & 14.2 & 118 & 4.39 & 0.99 \\
\hline HSJ-A1 & 39_S1 & Yes & 258865031 & 195569312 & 75.55 & 231004376 & 167708657 & 72.6 & 14.2 & 118 & 4.39 & 0.99 \\
\hline HSJ-A1 & 39_S1 & Yes & 275578087 & 209212979 & 75.92 & 244446390 & 178081282 & 72.85 & 14.9 & 114 & 4.57 & 0.99 \\
\hline HSJ-A1 & 39_S1 & Yes & 277565387 & 210155661 & 75.71 & 246316729 & 178907003 & 72.63 & 14.9 & 114 & 4.58 & 0.99 \\
\hline HSJ-A-1 & 2_P1 & Yes & 288594731 & 189609855 & 65.7 & 214257463 & 115272587 & 53.8 & 39.2 & 108 & 2.7 & 0.92 \\
\hline KNS-A1 & 52_S1 & Yes & 276846239 & 126459508 & 45.68 & 198299728 & 47912997 & 24.16 & 62.1 & 103 & 0.72 & 0.48 \\
\hline KNS-A1 & 52_S1 & Yes & 313445420 & 137826293 & 43.97 & 223327861 & 47708734 & 21.36 & 65.4 & 98 & 0.73 & 0.48 \\
\hline KOV-A2 & 3_P1 & Yes & 127306063 & 127306063 & 37.09 & 267735210 & 51844301 & 19.36 & 59.3 & 83 & 0.69 & 0.45 \\
\hline MKR-A1 & 49_P1 & Yes & 338463336 & 169673733 & 50.13 & 194788951 & 25999348 & 13.35 & 84.7 & 102 & 0.23 & 0.16 \\
\hline NNM-A1 & 50_P1 & Yes & 212025629 & 88107388 & 41.56 & 169053463 & 45135222 & 26.7 & 48.8 & 97 & 0.51 & 0.38 \\
\hline NPR-A2 & 62_P1 & Yes & 118916533 & 118916533 & 36.84 & 254251853 & 50381029 & 19.82 & 57.6 & 70 & 0.64 & 0.43 \\
\hline ORE-A1 & 56_S1 & Yes & 232416772 & 79568411 & 63.91 & 48563478 & 29196363 & 60.12 & 63.3 & 119 & 0.48 & 0.31 \\
\hline SBT-A1 & 66_S1 & Yes & 246712167 & 201207825 & 81.56 & 161584163 & 116079821 & 71.84 & 42.3 & 116 & 0.96 & 0.73 \\
\hline SBT-A1 & 66_S1 & Yes & 292536776 & 241197984 & 82.45 & 125998969 & 125998969 & 71.05 & 47.8 & 108 & 1 & 0.75 \\
\hline SBT-A1 & 66_S1 & No & 208402396 & 133191914 & 63.91 & 197557009 & 122346527 & 61.93 & 8.1 & 98 & 3.69 & 0.94 \\
\hline SBT-A1 & 66_P1 & Yes & 232684639 & 154280574 & 66.3 & 219449833 & 141045768 & 64.27 & 8.6 & 89 & 3.73 & 0.95 \\
\hline SBT-A1 & 66_S1 & No & 217957154 & 141317196 & 64.84 & 205882343 & 129242385 & 62.77 & 8.5 & 89 & 3.9 & 0.95 \\
\hline SSG-A2 & 67_P2 & No & 273323781 & 51511862 & 18.85 & 269841029 & 48029110 & 17.8 & 6.7 & 75 & 1.14 & 0.67 \\
\hline SSG-A2 & 67_P2 & No & 282549156 & 55378994 & 19.6 & 278554045 & 51383883 & 18.45 & 7.2 & 75 & 1.2 & 0.7 \\
\hline SSG-A2 & 67_P2 & No & 279751689 & 58656670 & 20.97 & 273834435 & 52739416 & 19.26 & 10.1 & 76 & 1.26 & 0.73 \\
\hline SSG-A2 & 67_P2 & No & 309035007 & 65039734 & 21.05 & 303628198 & 59632925 & 19.64 & 8.3 & 75 & 1.39 & 0.77 \\
\hline SSG-A2 & 67_S1 & Yes & 245090998 & 156524811 & 63.86 & 208851482 & 120285295 & 57.59 & 23.2 & 95 & 1.4 & 0.89 \\
\hline SSG-A2 & 67_S1 & Yes & 247752596 & 158105644 & 63.82 & 210835097 & 121188145 & 57.48 & 23.3 & 95 & 1.43 & 0.89 \\
\hline SSG-A2 & 67_S1 & Yes & 283443406 & 188708599 & 66.58 & 235622612 & 140887805 & 59.79 & 25.3 & 93 & 2.72 & 0.92 \\
\hline
\end{tabular}




\begin{tabular}{|c|c|c|c|c|c|c|c|c|c|c|c|c|}
\hline SSG-A2 & 67_S1 & Yes & 295423134 & 191226474 & 64.73 & 142496799 & 142496799 & 57.76 & 25.5 & 93 & 2.74 & 0.93 \\
\hline SSG-A3 & 58_P2 & Yes & 291970190 & 81214988 & 27.82 & 240288191 & 29532989 & 12.29 & 63.6 & 83 & 0.31 & 0.22 \\
\hline SSG-A4 & 63_s1 & Yes & 270354863 & 211756142 & 78.33 & 160144559 & 101545838 & 63.41 & 52 & 98 & 0.85 & 0.65 \\
\hline SSG-A4 & 63_S1 & Yes & 269030789 & 211431179 & 78.59 & 159071895 & 101472285 & 63.79 & 52 & 100 & 0.85 & 0.65 \\
\hline SSG-A4 & 63_P1 & Yes & 216706160 & 138219100 & 63.78 & 169804761 & 91317701 & 53.78 & 33.9 & 65 & 1.19 & 0.72 \\
\hline SSG-A4 & 63_P1 & Yes & 361511422 & 250439573 & 69.28 & 244972090 & 133900241 & 54.66 & 46.5 & 64 & 1.38 & 0.82 \\
\hline SSG-A4 & 63_P2 & Yes & 285994792 & 189371075 & 66.21 & 222165362 & 125541645 & 56.51 & 33.7 & 84 & 1.3 & 0.85 \\
\hline SSG-A4 & 63_P2 & Yes & 287085611 & 189400879 & 65.97 & 223737064 & 126052332 & 56.34 & 33.4 & 88 & 1.3 & 0.85 \\
\hline SSJ-A2 & 77_S1 & Yes & 98953193 & 51993207 & 52.54 & 71042878 & 24082892 & 33.9 & 53.7 & 125 & 0.4 & 0.27 \\
\hline STT-A2 & 74_P1 & Yes & 279871003 & 153982319 & 55.02 & 182182703 & 56294019 & 30.9 & 63.4 & 90 & 0.82 & 0.52 \\
\hline STT-A2 & 74_S1 & Yes & 227525447 & 167042213 & 73.42 & 200290765 & 139807531 & 69.8 & 16.3 & 112 & 2.96 & 0.95 \\
\hline STT-A2 & 74_S1 & Yes & 230430139 & 168857804 & 73.28 & 202932787 & 141360452 & 69.66 & 16.3 & 112 & 2.97 & 0.95 \\
\hline STT-A2 & 74_S1 & Yes & 239372866 & 176721169 & 73.83 & 210042923 & 147391226 & 70.17 & 16.6 & 108 & 3.01 & 0.96 \\
\hline STT-A2 & 74_S1 & Yes & 237989922 & 175832545 & 73.88 & 209759497 & 147602120 & 70.37 & 16.1 & 109 & 3.02 & 0.96 \\
\hline SUB-B1 ${ }^{*}$ & 100_P1* & Yes & 218976406 & 136064613 & 62.14 & 169074983 & 86163190 & 50.96 & 36.7 & 69 & 0.82 & 0.58 \\
\hline SVK-A1 & 70_S1 & Yes & 274607770 & 112221111 & 40.87 & 238704721 & 76318062 & 31.97 & 32 & 126 & 1.11 & 0.73 \\
\hline TGS-A1 & 8_P1 & Yes & 257789798 & 183690530 & 71.26 & 86362934 & 86362934 & 53.82 & 53 & 78 & 1.01 & 0.64 \\
\hline PSK-A26 & 9_P1 & Yes & 282421266 & 176969238 & 62.66 & 129361464 & 23909436 & 18.48 & 86.5 & 79 & 0.14 & 0.11 \\
\hline PSK-A26 & 9_P1 & Yes & 243301319 & 103301941 & 42.46 & 200101054 & 60101676 & 30.04 & 41.8 & 82 & 0.91 & 0.58 \\
\hline VDP-A5 & 97_S1 & Yes & 308029269 & 224948773 & 73.03 & 164359090 & 81278594 & 49.45 & 63.9 & 108 & 0.64 & 0.47 \\
\hline VDP-A5 & 97_P1 & Yes & 201938806 & 118188301 & 58.53 & 152583724 & 68833219 & 45.11 & 41.8 & 85 & 1.06 & 0.66 \\
\hline VDP-A5 & 97_P1 & Yes & 210235653 & 122381387 & 58.21 & 158714718 & 70860452 & 44.65 & 42.1 & 85 & 1.07 & 0.66 \\
\hline VDP-A5 & 97_P1 & Yes & 211926473 & 123422332 & 58.24 & 159638187 & 71134046 & 44.56 & 42.4 & 85 & 1.07 & 0.67 \\
\hline VDP-A5 & 97_P1 & Yes & 223494645 & 129585631 & 57.98 & 167880062 & 73971048 & 44.06 & 42.9 & 85 & 1.09 & 0.67 \\
\hline VDP-A5 & 97_P1 & Yes & 311609897 & 169950822 & 54.54 & 233797876 & 92138801 & 39.41 & 45.8 & 86 & 1.14 & 0.72 \\
\hline VDP-A6 & 94_P1 & Yes & 291553062 & 125784181 & 43.14 & 195912238 & 30143357 & 15.39 & 76 & 104 & 0.31 & 0.21 \\
\hline VDP-A6 & 94_S1 & Yes & 335276781 & 285170998 & 85.06 & 171141994 & 121036211 & 70.72 & 57.6 & 130 & 0.93 & 0.69 \\
\hline VDP-A6 & 94_S1 & Yes & 338329991 & 288018954 & 85.13 & 172178102 & 121867065 & 70.78 & 57.7 & 132 & 0.93 & 0.69 \\
\hline VDP-A7 & 101_P1 & Yes & 235798021 & 101426904 & 43.01 & 178215657 & 43844540 & 24.6 & 56.8 & 90 & 0.77 & 0.5 \\
\hline VDP-A7 & 101_P2 & Yes & 240990132 & 118807912 & 49.3 & 208859871 & 86677651 & 41.5 & 27 & 117 & 0.93 & 0.7 \\
\hline
\end{tabular}




\begin{tabular}{llrrrrrrrrrrr} 
VDP-A7 & 101_P2 & Yes & 302961387 & 147897392 & 48.82 & 254560930 & 99496935 & 39.09 & 32.7 & 112 & 1.02 & 0.75 \\
YGS-B2 & $92 \_1$ & No & 315058614 & 4893032 & 1.55 & 314071208 & 3905626 & 1.24 & 20.2 & 79 & 0.07 & 0.06 \\
YGS-B2 & $92 \_P 1$ & Yes & 243688076 & 127549142 & 52.34 & 155241741 & 39102807 & 25.19 & 69.3 & 63 & 0.37 & 0.26 \\
\hline
\end{tabular}


Table S4. DNA contamination estimates based on the mtDNA and the $\mathbf{X}$ chromosome for males. The table records the contamination point estimates and p-values, the average depth of sequence coverage (DoC) for the mitochondrial genome and the $\mathrm{X}$ chromosome, and the predicted sex cell karyotype. Contamination estimates based on the X chromosome were conducted on all males. Contamination $>5 \%$ (red) and P-values $>0.05$ (bold) are highlighted. Two libraries (bold red) with point estimates $>5 \%$ were excluded from downstream analysis.

\begin{tabular}{|c|c|c|c|c|c|c|c|c|c|c|c|c|c|c|c|}
\hline & & CHRM & & & & & & CHRX & METHOD 1 & & & METHOD 2 & & & \\
\hline Sample & $\begin{array}{l}\text { Library } \\
\text { ID }\end{array}$ & $\begin{array}{r}\text { DoC } \\
(q 20) \\
{[X]}\end{array}$ & $\begin{array}{r}\text { Minor } \\
\text { allele } \\
\text { frequency } \\
\text { in the } \\
\text { Icelandic } \\
\text { cohort - } \\
\text { less than } \\
{[\%]}\end{array}$ & $\begin{array}{r}\text { Mean } \\
\text { mismatch } \\
\text { at non-MD } \\
\text { rare } \\
\text { derived } \\
\text { alleles } \\
\text { (positions) } \\
\end{array}$ & $\begin{array}{r}95 \% \\
\mathrm{Cl}\end{array}$ & $\begin{array}{l}\text { Contamination } \\
\text { at possible } \\
\text { damaged rare } \\
\text { derived alleles } \\
\text { (positions) }\end{array}$ & $\begin{array}{l}95 \% \\
\mathrm{Cl}\end{array}$ & $\begin{array}{l}\text { DoC } \\
\text { (q30) } \\
{[X]}\end{array}$ & $\begin{array}{l}\text { Contamination } \\
\text { estimate [\%] }\end{array}$ & SE & p-value & $\begin{array}{r}\text { Contamination } \\
\text { estimate [\%] }\end{array}$ & SE & p-value & $\begin{array}{r}\text { Sex } \\
\text { chr. } \\
\text { karyo- } \\
\text { type }\end{array}$ \\
\hline $\begin{array}{l}\text { DAV- } \\
\text { A8 }\end{array}$ & $\begin{array}{l}\text { 25_P1 } \\
\text { 25_S1 }\end{array}$ & 448 & 5 & 0 & NA & $6.03(1)$ & $\begin{array}{r}4.08- \\
8.76\end{array}$ & 2.725 & NA & NA & NA & NA & NA & NA & $X X$ \\
\hline $\begin{array}{l}\text { DAV- } \\
\text { A9 }\end{array}$ & $\begin{array}{l}\text { 26_P1 } \\
\text { 26_P2 }\end{array}$ & 2153 & 5 & 0 & NA & $7.16(1)$ & $\begin{array}{r}6.15- \\
8.32\end{array}$ & 0.244 & 0.2 & 0.13 & 0.3357 & 0.47 & 0.29 & 0.07174 & $X Y$ \\
\hline $\begin{array}{l}\text { DKS- } \\
\text { A1 }\end{array}$ & $\begin{array}{l}\text { 27_P1 } \\
27 \_S 1\end{array}$ & 19967 & 5 & $0.28(7)$ & $\begin{array}{r}0.25- \\
0.31\end{array}$ & $0.4(3)$ & $\begin{array}{r}3.75- \\
4.1\end{array}$ & 0.363 & 1.11 & 0.22 & $\begin{array}{r}<2.20 \mathrm{E}- \\
16\end{array}$ & 0.71 & 0.34 & 0.00012 & $X Y$ \\
\hline $\begin{array}{l}\text { FOV- } \\
\text { A1 }\end{array}$ & $\begin{array}{l}\text { 32_P1 } \\
\text { 32_P2 }\end{array}$ & 1485 & 5 & $1.08(2)$ & $\begin{array}{r}0.64- \\
1.56\end{array}$ & $2.94(2)$ & $\begin{array}{r}2.45- \\
3.81\end{array}$ & 0.396 & 1.04 & 0.2 & 3.97E-09 & 0.64 & 0.28 & 0.01448 & $X Y$ \\
\hline FSS-A1 & 34_P1 & 445 & 5 & $0.09(3)$ & $\begin{array}{r}0.004- \\
0.54\end{array}$ & $10.52(6)$ & $\begin{array}{r}8.96- \\
11.49\end{array}$ & 0.918 & NA & NA & NA & NA & NA & NA & $X X$ \\
\hline $\begin{array}{l}\text { GRS- } \\
\text { A1 }\end{array}$ & $\begin{array}{l}\text { 38_P1 } \\
\text { 38_P2 }\end{array}$ & 1279 & 5 & $4.28(5)$ & $4.24-5$ & $4.3(6)$ & $\begin{array}{l}3.8- \\
4.73\end{array}$ & 0.338 & 2.99 & 0.41 & $\begin{array}{r}<2.20 \mathrm{E}- \\
16\end{array}$ & 3.59 & 0.7 & $9.41 \mathrm{E}-16$ & $X Y$ \\
\hline \multirow[t]{3}{*}{$\begin{array}{l}\text { GTE- } \\
\text { A1 }\end{array}$} & $\begin{array}{l}\text { 44_P1 } \\
\text { 44_S1* }\end{array}$ & 19990 & 5 & $11.77(5)$ & $\begin{array}{r}11.52- \\
11.94\end{array}$ & $13.91(4)$ & $\begin{array}{r}13.67- \\
14.15\end{array}$ & 0.782 & 14.5 & 0 & $\begin{array}{r}<2.20 \mathrm{E}- \\
16\end{array}$ & 12.09 & 1.05 & $\begin{array}{r}<2.20 \mathrm{E}- \\
16\end{array}$ & $X Y$ \\
\hline & 44_P1 & 6007 & 5 & $0.17(5)$ & $\begin{array}{r}0.13- \\
0.23\end{array}$ & $3.41(4)$ & $\begin{array}{l}3.3- \\
3.78\end{array}$ & 0.125 & 0.57 & 0.27 & 0.000929 & 0.94 & 0.43 & 0.002988 & $X Y$ \\
\hline & 44_S1* & 13844 & 5 & $14.17(5)$ & $\begin{array}{r}13.89- \\
14.38\end{array}$ & $16.18(4)$ & $\begin{array}{r}15.9- \\
16.46\end{array}$ & 0.242 & 15.41 & 0 & $\begin{array}{r}<2.20 \mathrm{E}- \\
16\end{array}$ & 12.26 & 0.00001 & $\begin{array}{r}<2.20 \mathrm{E}- \\
16\end{array}$ & $X Y$ \\
\hline HSJ-A1 & $\begin{array}{l}\text { 2_P1 } \\
2-P 2 \\
\text { 39_P1 } \\
\text { 39_S1 }\end{array}$ & 18484 & 5 & $1.3(3)$ & $\begin{array}{r}1.18- \\
1.38\end{array}$ & $6.7(4)$ & $\begin{array}{r}4.97- \\
5.32\end{array}$ & 14.214 & 0.52 & 0 & $\begin{array}{r}<2.20 \mathrm{E}- \\
16\end{array}$ & 0.53 & 0 & 7.91E-08 & $X Y$ \\
\hline
\end{tabular}




\begin{tabular}{|c|c|c|c|c|c|c|c|c|c|c|c|c|c|c|c|}
\hline $\begin{array}{l}\text { KNS- } \\
\mathrm{A} 1\end{array}$ & $52 \_s 1$ & 1550 & 10 & $0.81(1)$ & $\begin{array}{r}0.4- \\
1.59\end{array}$ & 3.87 (1) & $\begin{array}{r}2.79- \\
5.33\end{array}$ & 0.437 & 0.37 & 0.11 & 0.00052 & 0.41 & 0.19 & 0.02273 & $X Y$ \\
\hline $\begin{array}{l}\text { KOV- } \\
\text { A2 }\end{array}$ & 3_P1 & 3925 & 5 & $0.34(3)$ & $\begin{array}{c}0.24- \\
0.47\end{array}$ & 0 & NA & 0.306 & 0.46 & 0.16 & 0.0003 & 0.88 & 0.31 & 0.00021 & $X Y$ \\
\hline $\begin{array}{l}\text { MKR- } \\
\text { A1 }\end{array}$ & 49_P1 & 1496 & 5 & $0.26(1)$ & $\begin{array}{r}0.07- \\
0.83\end{array}$ & $13(3)$ & $\begin{array}{r}11.57- \\
13.51\end{array}$ & 0.093 & 0.08 & 0.09 & 0.2877 & 0.08 & 0.14 & 0.7294 & $X Y$ \\
\hline $\begin{array}{l}\text { NNM- } \\
\text { A1 }\end{array}$ & 50_P1 & 420 & 5 & $0.27(4)$ & $\begin{array}{r}0.09- \\
0.73\end{array}$ & $5.34(2)$ & $\begin{array}{r}3.82- \\
7.31\end{array}$ & 0.324 & 0.49 & 0.27 & 0.02491 & 0.35 & 0.4 & 0.2588 & $X Y$ \\
\hline $\begin{array}{l}\text { ORE- } \\
\text { A1 }\end{array}$ & 56_S1 & 739 & 5 & $0.67(3)$ & $\begin{array}{r}0.36- \\
1.18\end{array}$ & $2.43(3)$ & $\begin{array}{r}1.43- \\
3.07\end{array}$ & 0.236 & 0.28 & 0.16 & 0.1879 & 0.26 & 0.27 & 0.1951 & $X Y$ \\
\hline SBT-A1 & $\begin{array}{l}\text { 66_P1 } \\
\text { 66_P2 }\end{array}$ & 1775 & 5 & $0.75(1)$ & $\begin{array}{r}0.37- \\
1.48\end{array}$ & $2.53(5)$ & $\begin{array}{l}2.0- \\
2.66\end{array}$ & 2.422 & 1.08 & 0.04 & $\begin{array}{r}<2.20 \mathrm{E}- \\
16\end{array}$ & 1.01 & 0.07 & $8.46 \mathrm{E}-13$ & $X Y$ \\
\hline $\begin{array}{l}\text { SSG- } \\
\text { A2 }\end{array}$ & $\begin{array}{l}\text { 67_P2 } \\
67 \_S 1\end{array}$ & 423 & 5 & $0.32(2)$ & $\begin{array}{r}0.09- \\
1.05\end{array}$ & $0.5(1)$ & $\begin{array}{r}0.09- \\
1.98\end{array}$ & 5.247 & 1.2 & 0 & $\begin{array}{r}<2.20 \mathrm{E}- \\
16\end{array}$ & 1.32 & 0 & $\begin{array}{r}<2.20 \mathrm{E}- \\
16\end{array}$ & $X Y$ \\
\hline $\begin{array}{l}\text { SSG- } \\
\text { A3 }\end{array}$ & 58_P1 & 3744 & 5 & $0.21(2)$ & $\begin{array}{r}0.11- \\
0.38\end{array}$ & $2.51(1)$ & $\begin{array}{r}2.06- \\
3.07\end{array}$ & 0.151 & 0.56 & 0.51 & 0.3928 & 0.15 & 1.14 & 0.07615 & $X Y$ \\
\hline $\begin{array}{l}\text { SSG- } \\
\text { A4 }\end{array}$ & $\begin{array}{l}\text { 63_P1 } \\
\text { 63_P2 } \\
\text { 63_S1 }\end{array}$ & 441 & 5 & 0.29 (1) & $\begin{array}{r}0.02- \\
1.83\end{array}$ & 2.77 (1) & $\begin{array}{r}1.46- \\
5.05\end{array}$ & 6.81 & NA & NA & NA & NA & NA & NA & $X X$ \\
\hline SSJ-A2 & 77_S1 & 1306 & 10 & $0.33(2)$ & $\begin{array}{r}0.15- \\
0.76\end{array}$ & $3.09(10)$ & $\begin{array}{r}2.75- \\
3.39\end{array}$ & 0.223 & 0.34 & 0.23 & 0.05999 & 0.06 & 0.11 & 1 & $X Y$ \\
\hline STT-A2 & $\begin{array}{l}\text { 74_P1 } \\
\text { 74_S1 }\end{array}$ & 2618 & 5 & $0.13(3)$ & $\begin{array}{r}0.06- \\
0.25\end{array}$ & $1.23(13)$ & $\begin{array}{r}1.13- \\
1.37\end{array}$ & 5.541 & 0.43 & 0 & $\begin{array}{r}<2.20 \mathrm{E}- \\
16\end{array}$ & 3.80E-01 & 0 & 5.09E-05 & $X Y$ \\
\hline $\begin{array}{l}\text { SUB- } \\
\text { B1 }\end{array}$ & 100_P1* & 264 & 5 & $6.32(1)$ & $\begin{array}{c}3.84- \\
10.11\end{array}$ & $8.62(7)$ & $\begin{array}{c}7.45- \\
10.08\end{array}$ & 0.475 & 2.45 & 0.38 & $9.14 \mathrm{E}-13$ & 2.11 & 0.58 & 7.37E-05 & $X Y$ \\
\hline SVK-A1 & 70_S1 & 5982 & 5 & $1.15(5)$ & $\begin{array}{r}0.52- \\
0.74\end{array}$ & $4.87(9)$ & $\begin{array}{r}4.26- \\
4.66\end{array}$ & 0.751 & 0.56 & 0.1 & 8.31E-05 & 0.67 & 0.16 & 0.00337 & $X Y$ \\
\hline $\begin{array}{l}\text { TGS- } \\
\text { A1 }\end{array}$ & 8_P1 & 457 & 5 & $2.04(2)$ & $\begin{array}{r}0.88- \\
3.06\end{array}$ & 0 & NA & 0.576 & 0.59 & 0.17 & 0.00019 & 0.63 & 0.26 & 0.01147 & $X Y$ \\
\hline $\begin{array}{l}\text { VDP- } \\
\text { A5 }\end{array}$ & $\begin{array}{l}\text { 97_P1 } \\
\text { 97_S1 }\end{array}$ & 4899 & 5 & 0 & NA & $4.42(1)$ & $\begin{array}{r}3.86- \\
5.04\end{array}$ & 1.01 & NA & NA & NA & NA & NA & NA & $X X$ \\
\hline $\begin{array}{l}\text { VDP- } \\
\text { A6 }\end{array}$ & $\begin{array}{l}\text { 101_P1 } \\
\text { 101_S1 }\end{array}$ & 1416 & 5 & $1.38(1)$ & $\begin{array}{r}0.79- \\
2.36\end{array}$ & $3.25(5)$ & $\begin{array}{r}2.84- \\
3.76\end{array}$ & 0.599 & 0.92 & 0.02 & $\begin{array}{r}<2.20 \mathrm{E}- \\
16\end{array}$ & 0.95 & 0.05 & $8.02 E-14$ & $X Y$ \\
\hline $\begin{array}{l}\text { VDP- } \\
\text { A7 }\end{array}$ & 94_S1 & 7623 & 5 & 0.06 (3) & $\begin{array}{r}0.91- \\
1.08\end{array}$ & $1.58(4)$ & $\begin{array}{r}1.47- \\
1.75\end{array}$ & 1.006 & 0.6 & 0.02 & $\begin{array}{r}<2.20 \mathrm{E}- \\
16\end{array}$ & 0.73 & 0.05 & $1.05 \mathrm{E}-10$ & $X Y$ \\
\hline
\end{tabular}




\begin{tabular}{|c|c|c|c|c|c|c|c|c|c|c|c|c|c|c|c|}
\hline $\begin{array}{l}\text { YGS- } \\
\text { B2 }\end{array}$ & 92_P1 & 763 & 5 & $0.66(4)$ & $\begin{array}{r}0.21- \\
1.79\end{array}$ & $4.53(4)$ & $\begin{array}{r}3.82- \\
5.3\end{array}$ & 0.237 & NA & NA & NA & NA & NA & NA & $X X Y$ \\
\hline $\begin{array}{l}\text { PSK- } \\
\text { A26 }\end{array}$ & 9_P1 & 1673 & 5 & $1.63(1)$ & $\begin{array}{r}0.97- \\
2.69\end{array}$ & $3.43(1)$ & $\begin{array}{r}2.61- \\
4.47\end{array}$ & 0.423 & 1.58 & 0.26 & $1.57 \mathrm{E}-15$ & 1.18 & 0.4 & 5.64E-05 & $X Y$ \\
\hline
\end{tabular}


Table S5. Mitochondrial motifs based on WGS and PCR amplification.

\begin{tabular}{|c|c|c|c|c|c|c|}
\hline Sample & $\begin{array}{l}\text { WGS-based } \\
\text { motif } 16055- \\
16410\end{array}$ & $\begin{array}{l}\text { PCR-based } \\
\text { motif } 16055- \\
16410\end{array}$ & $\begin{array}{l}\text { WGS-based } \\
\text { motif 16517-409 }\end{array}$ & $\begin{array}{l}\text { PCR-based } \\
\text { motif 16517- } \\
409\end{array}$ & WGS-based full haplogroup motifs & $\begin{array}{l}\text { Haplogroup } \\
\text { assignment }\end{array}$ \\
\hline DAV-A8 & & & 16519C 263G & 16519C 263G & $\begin{array}{l}\text { 263G 750G 1438G 3010A 4769G 8860G 9163C } \\
\text { 15326G 16519C }\end{array}$ & $\mathrm{H} 1$ \\
\hline DAV-A9 & & & 16519C 263G & $16519 C 263 G$ & $\begin{array}{l}\text { 263G 750G 1438G 3010A 4769G 8860G 9163C } \\
\text { 15326G 16519C }\end{array}$ & $\mathrm{H} 1$ \\
\hline DKS-A1 & $\begin{array}{l}\text { 16192T } 16239 T \\
\text { 16256T 16270T } \\
\text { 16399G }\end{array}$ & $\begin{array}{l}\text { 16192T } 16239 T \\
\text { 16256T } 16270 \mathrm{~T} \\
\text { 16399G }\end{array}$ & 73G 150T 263G & $\begin{array}{l}73 G 150 T \\
263 G\end{array}$ & $\begin{array}{l}\text { 73G 150T 263G 750G 1303A 1438G 2706G 3192T } \\
\text { 3197C 3591A 4592C 4769G 7028T 8860G 9477A } \\
\text { 11296T 11467G 11719A 11938T 12308G 12372A } \\
\text { 12618A 13617C 14766T 14793G 15218G 15326G } \\
\text { 16192T 16239T 16256T 16270T 16399G }\end{array}$ & U5a1h \\
\hline FOV-A-1 & $16111 \mathrm{~T} 16311 \mathrm{C}$ & $\begin{array}{l}16111 \mathrm{~T} \\
16311 \mathrm{C}\end{array}$ & $263 G$ & $263 G$ & $\begin{array}{l}\text { 263G 549T 750G 1438G 2706G 3397G 4769G } \\
\text { 7028T 8460G 8860G 15326G 16111T 16311C }\end{array}$ & HV17a \\
\hline FSS-A1 & $16356 \mathrm{C}$ & $16356 \mathrm{C}$ & $\begin{array}{l}16519 C 73 G \\
195 C 263 G\end{array}$ & $\begin{array}{l}16519 C 73 G \\
195 C 263 G\end{array}$ & $\begin{array}{l}\text { 73G 195C 263G 499A 750G 1438G 1811G 2706G } \\
\text { 4646C 4703C 4769G 5999C 6047G 7028T 8818T } \\
\text { 8860G 11332T 11467G 11719A 12308G 12372A } \\
\text { 14620T 14766T 15326G 15693C 16356C 16519C }\end{array}$ & U4a2 \\
\hline GRS-A-1 & $\begin{array}{l}16093 \mathrm{C} 16224 \mathrm{C} \\
16311 \mathrm{C}\end{array}$ & $\begin{array}{l}16093 C \\
16224 C \\
16311 C\end{array}$ & $\begin{array}{l}16519 C 73 G \\
114 T 263 G\end{array}$ & $\begin{array}{l}16519 C 73 G \\
114 T 263 G\end{array}$ & $\begin{array}{l}\text { 73G 114T 263G 497T 593C 750G 1189C 1438G } \\
\text { 1811G 2483C 2706G 3480G 4769G 7028T 8860G } \\
\text { 9055A 9698C 10398G 10550G 11299C 11467G } \\
\text { 11470G 11620G 11719A 11914A 12308G 12372A } \\
\text { 14167T 14766T 14798C 15924G 16093C 16224C } \\
\text { 16311C 16519C }\end{array}$ & K1a1b1b \\
\hline GTE-A1 & & & $195 C^{*} 263 G$ & $263 G$ & $\begin{array}{l}\text { 195C 263G 750G 1438G 3992T 4024G 4769G } \\
\text { 5004C 8269A 8860G 9123A 12642G 14365T } \\
\text { 14569A 14582G 15326G 15884A }\end{array}$ & H4a1a4b \\
\hline HSJ-A1 & & & $\begin{array}{l}16519 \mathrm{C} 46 \mathrm{C} \\
152 \mathrm{C}\end{array}$ & $\begin{array}{l}16519 \mathrm{C} 46 \mathrm{C} \\
152 \mathrm{C}\end{array}$ & $\begin{array}{l}\text { 46C 152C 750G 1438G 3992T 4418C 4769G 6776C } \\
8860 G \text { 9755A 10754C 15326G 16519C }\end{array}$ & $\mathrm{H} 3 \mathrm{~g} 1$ \\
\hline KNS-A1 & $16304 \mathrm{C} 16362 \mathrm{C}$ & $\begin{array}{l}16304 \mathrm{C} \\
16362 \mathrm{C}\end{array}$ & $263 G$ & $263 G$ & $\begin{array}{l}\text { 263G 456T 750G 1438G 4769G 8860G 15326G } \\
\text { 16304C 16362C }\end{array}$ & H5 \\
\hline KOV-A2 & $16234 \mathrm{~T}$ & $\begin{array}{l}16189 \mathrm{C} \\
16234 \mathrm{~T}\end{array}$ & 16519C 263G & 16519C 263G & $\begin{array}{l}\text { 263G 750G 1438G 3010A 4769G 8860G 12561A } \\
\text { 15047A 15326G 16189C 16234T 16519C }\end{array}$ & $\mathrm{H} 1$ \\
\hline MKR-A1 & $16224 \mathrm{C} 16311 \mathrm{C}$ & $\begin{array}{l}16224 C \\
16311 C\end{array}$ & $\begin{array}{l}16519 C 73 G \\
146 C 152 C \\
263 G\end{array}$ & $\begin{array}{l}16519 C 73 G \\
146 C 152 C \\
263 G\end{array}$ & $\begin{array}{l}\text { 73G 146C 152C 263G 750G 1189C 1438G 1811G } \\
\text { 2706G 3480G 4769G 7028T 8860G 9055A 9093G } \\
\text { 9698C 10398G 10550G 11299C 11377A 11467G } \\
\text { 11719A 12308G 12372A 13105G 14167T 14766T } \\
\text { 14798C 15326G 15900C 16224C 16311C 16519C }\end{array}$ & $\mathrm{K} 1 \mathrm{c} 1 \mathrm{~b}$ \\
\hline
\end{tabular}




\begin{tabular}{|c|c|c|c|c|c|c|}
\hline NNM-A1 & 16235G 16291T & $\begin{array}{l}16235 G \\
16291 T\end{array}$ & $263 G$ & $263 G$ & $\begin{array}{l}\text { 263G 8860G 11914A 12954C 14305A 15326G } \\
\text { 16235G 16291T }\end{array}$ & $\mathrm{H} 2 \mathrm{a} 2 \mathrm{~b} 5$ \\
\hline NPR-A2 & $\begin{array}{l}16224 C \text { 16249C } \\
16311 C\end{array}$ & $\begin{array}{l}16224 \mathrm{C} \\
16249 \mathrm{C} \\
16311 \mathrm{C}\end{array}$ & $\begin{array}{l}16519 C 73 G \\
263 G\end{array}$ & $\begin{array}{l}16519 C 73 G \\
263 G\end{array}$ & $\begin{array}{l}\text { 73G 263G 497T 750G 1189C 1438G 1811G 2706G } \\
\text { 3480G 4769G 5773A 6032A 7028T 8860G 9055A } \\
\text { 9698C 10398G 10550G 11025C 11299C 11467G } \\
\text { 11719A 12308G 12372A 12373G 13650T 14167T } \\
\text { 14766T 14798C 15326G 15495C 16224C 16249C } \\
\text { 16311C 16519C }\end{array}$ & $\mathrm{K} 1 \mathrm{a} 2 \mathrm{a}$ \\
\hline ORE-A1 & $\begin{array}{l}16224 \mathrm{C} 16311 \mathrm{C} \\
16362 \mathrm{C}\end{array}$ & $\begin{array}{l}16224 \mathrm{C} \\
16311 \mathrm{C} \\
16362 \mathrm{C}\end{array}$ & $\begin{array}{l}16519 C 73 G \\
263 G\end{array}$ & $\begin{array}{l}16519 C 73 G \\
263 G\end{array}$ & $\begin{array}{l}\text { 73G 263G 497T 750G 1189C 1438G 1811G 2251G } \\
\text { 2706G 3316A 3480G 4769G 7028T 7559G 8860G } \\
\text { 9055A 9698C 10398G 10550G 11299C 11467G } \\
\text { 11719A 11902A 12308G 12372A 13117G 14167T } \\
\text { 14766T 14798C 15326G 16224C 16311C 16362C } \\
\text { 16519C }\end{array}$ & K1a3a \\
\hline SBT-A1 & & & $\begin{array}{l}16519 C 152 C \\
263 G\end{array}$ & $\begin{array}{l}16519 C 152 C \\
263 G\end{array}$ & $\begin{array}{l}\text { 152C 263G 750G 1438G 3992T 4418C 4769G } \\
6776 C \text { 8860G 10754C 12965C 15326G 15377G } \\
\text { 16519C }\end{array}$ & H3g1a \\
\hline SSG-A2 & $16126 \mathrm{C}$ & $\begin{array}{l}16069 \mathrm{~T} \\
16126 \mathrm{C}\end{array}$ & $\begin{array}{l}73 G \text { 185A 263G } \\
295 T\end{array}$ & $\begin{array}{l}73 G 185 A \\
263 G 295 T\end{array}$ & $\begin{array}{l}\text { 73G 185A 263G 295T 462T 489C 750G 1438G } \\
\text { 2706G 3010A 4216C 4769G 6380G 7028T 8860G } \\
\text { 9755A 10398G 11251G 11719A 12612G 13708A } \\
\text { 13934T 14766T 14798C 15326G 15452A 16069T } \\
\text { 16126C }\end{array}$ & $\mathrm{J} 1 \mathrm{c} 3 \mathrm{~g}$ \\
\hline SSG-A3 & $16126 \mathrm{C}$ & $\begin{array}{l}16126 \mathrm{C} \\
16294 \mathrm{~T}\end{array}$ & $\begin{array}{l}16519 C 73 G \\
152 C 263 G\end{array}$ & $\begin{array}{l}16519 C 73 G \\
152 C 263 G\end{array}$ & $\begin{array}{l}\text { 73G 152C 263G 709A 750G 930A 1438G 1888A } \\
\text { 2706G 4216C 4769G 4917G 5147A 7028T 8697A } \\
\text { 8860G 10463C 11242G 11251G 11719A 11812G } \\
\text { 13368A 14233G 14766T 14905A 15326G 15452A } \\
\text { 15607G 15928A 16126C 16294T 16519C }\end{array}$ & $\mathrm{T} 2 \mathrm{~b} 2 \mathrm{~b}$ \\
\hline SSG-A4 & $\begin{array}{l}\text { 16069T 16126C } \\
\text { 16145A 16172C } \\
\text { 16192T 16261T }\end{array}$ & $\begin{array}{l}16069 \mathrm{~T} \\
16126 \mathrm{C} \\
16145 \mathrm{~A} \\
16172 \mathrm{C} \\
16192 \mathrm{~T} 16261 \mathrm{~T}\end{array}$ & $\begin{array}{l}\text { 73G 242T 263G } \\
295 T\end{array}$ & $\begin{array}{l}73 G 242 T \\
263 G 295 T\end{array}$ & $\begin{array}{l}\text { 73G 242T 263G 295T 462T 489C 750G 1438G } \\
\text { 2158C 2706G 3010A 4216C 4769G 5460A 5463T } \\
\text { 6911C 7028T 8269A 8557A 8860G 10398G 11251G } \\
\text { 11719A 12007A 12612G 13708A 13879C 14766T } \\
\text { 15326G 15452A 16069T 16126C 16145A 16172C } \\
\text { 16192T 16261T }\end{array}$ & J1b1a1a \\
\hline SSJ-A2 & $\begin{array}{l}\text { 16172C } 16256 \mathrm{~T} \\
16399 \mathrm{G}\end{array}$ & $\begin{array}{l}16172 \mathrm{C} \\
16256 \mathrm{~T} \\
16399 \mathrm{G}\end{array}$ & $73 G 263 G$ & $73 G 263 G$ & $\begin{array}{l}\text { 73G 263G 750G 1438G 1700C 2706G 3197C } \\
\text { 4769G 5495C 7028T 8705C 8860G 9477A 11467G } \\
\text { 11719A 12308G 12372A 13617C 14766T 14793G } \\
\text { 15218G 15326G 15924G 16172C 16256T 16399G }\end{array}$ & U5a1a1 \\
\hline STT-A2 & $16356 \mathrm{C}$ & $16356 \mathrm{C}$ & $\begin{array}{l}16519 C 73 G \\
152 C 195 C \\
263 G\end{array}$ & $\begin{array}{l}16519 C 73 G \\
152 C 195 C \\
263 G\end{array}$ & $\begin{array}{l}\text { 73G 152C 195C 263G 499A 750G 1438G 1811G } \\
\text { 2706G 4646C 4769G 5999C 6047G 7028T 7705C } \\
\text { 8308G 8860G 9389G 10819G 11332T 11339C } \\
\text { 11467G 11719A 12308G 12372A 13528G 13565T } \\
\text { 14620T 14766T 15326G 15373G 15693C 15758G } \\
\text { 16356C 16519C }\end{array}$ & U4b1b1 \\
\hline
\end{tabular}




\begin{tabular}{|c|c|c|c|c|c|c|}
\hline SVK-A1 & $\begin{array}{l}\text { 16129A } 16223 T \\
16391 \mathrm{~A}\end{array}$ & $\begin{array}{l}\text { 16129A } 16223 T \\
16391 \mathrm{~A}\end{array}$ & $\begin{array}{l}16519 \text { C 73G } \\
152 C 199 C \\
204 C 207 A \\
250 C 263 G \\
315 \_1 C\end{array}$ & $\begin{array}{l}16519 C 73 G \\
152 C 199 C \\
204 C 207 A \\
250 C 263 G \\
315 \_1 C\end{array}$ & $\begin{array}{l}\text { 73G 152C 199C 204C 207A 250C 263G 750G } \\
\text { 1438G 1719A 2706G 4529T 4769G 7028T 8251A } \\
\text { 8860G 9653C 10034C 10238C 10398G 11719A } \\
\text { 12501A 12705T 13780G 14766T 15043A 15326G } \\
\text { 15758G 15924G 16129A 16223T 16391A 16519C }\end{array}$ & 12 \\
\hline TGS-A1 & $\begin{array}{l}16126 \mathrm{C} \text { 16153A } \\
16294 \mathrm{~T}\end{array}$ & $\begin{array}{l}16126 \mathrm{C} \\
16153 \mathrm{~A} 16294 \mathrm{~T}\end{array}$ & $\begin{array}{l}\text { 16519C 41T } \\
73 G \text { 150T 263G }\end{array}$ & $\begin{array}{l}\text { 16519C } 41 T \\
73 G 150 T \\
263 G\end{array}$ & $\begin{array}{l}\text { 41T 73G 150T 263G 709A 750G 1438G 1888A } \\
\text { 2706G 4216C 4769G 4917G 7028T 8697A 8860G } \\
\text { 10463C 11251G 11719A 11812G 13368A 14233G } \\
\text { 14766T 14905A 15326G 15452A 15607G 15928A } \\
\text { 16126C 16153A 16294T 16519C }\end{array}$ & T2e1 \\
\hline VDP-A5 & & & $16519 \mathrm{C} 263 \mathrm{G}$ & $16519 \mathrm{C} 263 \mathrm{G}$ & $\begin{array}{l}\text { 263G 750G 1438G 4769G 6776C 8860G 15326G } \\
16519 C\end{array}$ & $\mathrm{H} 3$ \\
\hline VDP-A6 & 16176T 16219G & $\begin{array}{l}16176 \mathrm{~T} \\
16219 \mathrm{G}\end{array}$ & $\begin{array}{l}16519 C 146 C \\
257 G 263 G\end{array}$ & $\begin{array}{l}16519 C 146 C \\
257 G 263 G\end{array}$ & $\begin{array}{l}\text { 146C 257G 263G 477C 750G 1438G 3010A 4769G } \\
\text { 8473C 8860G 15326G 15758G 16176T 16219G } \\
\text { 16519C }\end{array}$ & $\mathrm{H} 1 \mathrm{c} 3 \mathrm{a}$ \\
\hline VDP-A7 & & & $263 G$ & $263 G$ & $\begin{array}{l}\text { 263G 750G 1438G 3992T 4024G 4769G 5004C } \\
\text { 8269A 8860G 9123A 10044G 14365T 14582G } \\
\text { 15326G }\end{array}$ & H4a1a1 \\
\hline YGS-B2 & $16126 \mathrm{C}$ & $\begin{array}{l}16069 \mathrm{~T} \\
16126 \mathrm{C}\end{array}$ & $\begin{array}{l}\text { 73G 228A 263G } \\
295 T\end{array}$ & $\begin{array}{l}73 G \text { 228A } \\
263 G 295 T\end{array}$ & $\begin{array}{l}\text { 73G 228A 263G 295T 462T 482C 489C 750G } \\
\text { 1438G 2706G 3010A 3394C 4216C 4769G 7028T } \\
\text { 8860G 9635C 10398G 11251G 11623T 11719A } \\
\text { 12612G 13708A 13899C 14766T 14798C 15326G } \\
\text { 15452A 16069T }\end{array}$ & J1c1a \\
\hline PSK-A26 & $\begin{array}{l}16126 \mathrm{C} 16145 \mathrm{~A} \\
16172 \mathrm{C} 16222 \mathrm{~T} \\
16261 \mathrm{~T}\end{array}$ & $\begin{array}{l}16069 \mathrm{~T} \\
16126 \mathrm{C} \\
16145 \mathrm{~A} \\
16172 \mathrm{C} \\
16192 \mathrm{~T} 16222 \mathrm{~T} \\
16261 \mathrm{~T}\end{array}$ & $\begin{array}{l}\text { 73G 242T 263G } \\
\text { 295T }\end{array}$ & $\begin{array}{l}73 G 242 T \\
263 G 295 T\end{array}$ & $\begin{array}{l}\text { 73G 242T 263G 295T 462T 489C 750G 1438G } \\
\text { 2158C 2706G 3010A 4216C 4769G 5460A 5463T } \\
\text { 6911C 7028T 8269A 8557A 8860G 10398G 11251G } \\
\text { 11719A 12007A 12612G 13708A 13879C 14766T } \\
\text { 15326G 15452A 16069T 16126C 16145A 16172C } \\
\text { 16192T 16222T }\end{array}$ & J1b1a1a \\
\hline
\end{tabular}

The position marked with an asterisk symbol (*) is the only one that differs between Sanger sequence and WGS data, which could be explained by the fact that it is heteroplasmic. 
Table S6. Inference of biological sex. Sequences with mapping quality of at least 30 were used. Statistics were computed using the $R y$ approach.

\begin{tabular}{|c|c|c|c|c|c|c|c|}
\hline Sample & $\begin{array}{r}\text { Number of } \\
\text { alignments to chrX } \\
\text { and chrY }\end{array}$ & $\begin{array}{r}\text { Number of } \\
\text { alignments to chrY }\end{array}$ & $R_{y}$ & SE & $95 \% \mathrm{Cl}$ & $\begin{array}{l}\text { Inferred sex } \\
\text { chr. karyotype }\end{array}$ & Inferred biological sex \\
\hline DAV-A8 & 8962496 & 18392 & 0.0021 & $1.00 \mathrm{E}-04$ & $0.002-0.0021$ & $\mathrm{XX}$ & Female \\
\hline DAV-A9 & 619099 & 68225 & 0.1102 & 0.0004 & $0.1094-0.111$ & $X Y$ & Male \\
\hline FOV-A1 & 968134 & 107001 & 0.1105 & 0.0003 & $0.1099-0.1111$ & $X Y$ & Male \\
\hline FSS-A1 & 2335627 & 5080 & 0.0022 & 1.00E-04 & $0.0021-0.0022$ & $X X$ & Female \\
\hline GRS-A1 & 797055 & 77530 & 0.0973 & 0.0003 & $0.0966-0.0979$ & $X Y$ & Male \\
\hline GTE-A1 & 361200 & 40198 & 0.1113 & 0.0005 & $0.1103-0.1123$ & $X Y$ & Male \\
\hline KNS-A1 & 1063798 & 121868 & 0.1146 & 0.0003 & $0.114-0.1152$ & $X Y$ & Male \\
\hline KOV-A2 & 862231 & 92555 & 0.1073 & 0.0003 & $0.1067-0.108$ & $X Y$ & Male \\
\hline MKR-A1 & 425384 & 46790 & 0.11 & 0.0005 & $0.1091-0.1109$ & $X Y$ & Male \\
\hline NNM-A1 & 699499 & 79886 & 0.1142 & 0.0004 & $0.1135-0.1149$ & $X Y$ & Male \\
\hline NPR-A2 & 1025445 & 2624 & 0.0026 & $1.00 \mathrm{E}-04$ & $0.0025-0.0027$ & $X X$ & Female \\
\hline ORE-A1 & 480412 & 62833 & 0.1308 & 0.0005 & $0.1298-0.1317$ & $X Y$ & Male \\
\hline SBT-A1 & 7731038 & 803053 & 0.1039 & 0.0001 & $0.1037-0.1041$ & $X Y$ & Male \\
\hline SSG-A2 & 10354341 & 1007151 & 0.0973 & 0.0001 & $0.0971-0.0974$ & $X Y$ & Male \\
\hline SSG-A3 & 295126 & 30886 & 0.1047 & 0.0006 & $0.1035-0.1058$ & $X Y$ & Male \\
\hline SSG-A4 & 14111563 & 25079 & 0.0018 & 0 & $0.0018-0.0018$ & $X X$ & Female \\
\hline STT-A2 & 12970412 & 1394719 & 0.1075 & 0.0001 & $0.1074-0.1077$ & $X Y$ & Male \\
\hline SVK-A-1 & 1733259 & 205367 & 0.1185 & 0.0002 & 0.118-0.119 & $X Y$ & Male \\
\hline TGS-A1 & 1348489 & 135371 & 0.1004 & 0.0003 & $0.0999-0.1009$ & $X Y$ & Male \\
\hline VDP-A5 & 6727199 & 19049 & 0.0028 & $1.00 \mathrm{E}-04$ & $0.0028-0.0029$ & $X X$ & Female \\
\hline VDP-A6 & 4364988 & 485617 & 0.1113 & 0.0002 & $0.111-0.1115$ & $X Y$ & Male \\
\hline VDP-A7 & 4281340 & 569778 & 0.1331 & 0.0002 & $0.1328-0.1334$ & $X Y$ & Male \\
\hline YGS-B2 & 558974 & 29906 & 0.0535 & 0.0003 & $0.0529-0.0541$ & $X X Y$ & Male Klinefelter syndrome \\
\hline PSK-A26 & 1072265 & 114549 & 0.1068 & 0.0003 & $0.1062-0.1074$ & $X Y$ & Male \\
\hline
\end{tabular}


Table S7. Summary of reference data used in this study.

\begin{tabular}{|c|c|c|}
\hline Study and Chip type & $\begin{array}{r}\text { European } \\
\text { panel. } \\
\text { no. of } \\
\text { samp. }\end{array}$ & $\begin{array}{r}\text { North } \\
\text { European } \\
\text { panel. } \\
\text { no. of } \\
\text { samp. }\end{array}$ \\
\hline $\begin{array}{l}\text { This study } \\
\text { Illumina Human Omni Express chip }\end{array}$ & 973 & 4224 \\
\hline Sweden & 194 & 1,103 \\
\hline Norway & 193 & 1,035 \\
\hline Denmark & 199 & 980 \\
\hline Iceland & 197 & 916 \\
\hline $\begin{array}{l}\text { The "Irish DNA Atlas" } \\
\text { Illumina Human Omni Express chip }\end{array}$ & 190 & 190 \\
\hline Ireland & 190 & 190 \\
\hline $\begin{array}{l}\text { Leslie et al. (2015) } \\
\text { Illumina Human } 1 M \text { chip and Affymetrix 500K SNP }\end{array}$ & 562 & 1246 \\
\hline Wales & 130 & 130 \\
\hline Gwynedd & 76 & 76 \\
\hline Dyfed & 54 & 54 \\
\hline England & 200 & 882 \\
\hline Midlands & 45 & 219 \\
\hline North East & 24 & 96 \\
\hline North West & 23 & 95 \\
\hline South East & 45 & 203 \\
\hline South West & 31 & 174 \\
\hline Yorkshire & 32 & 95 \\
\hline Northern Ireland & 40 & 40 \\
\hline Scotland & 192 & 194 \\
\hline Dumfries and Galloway & 42 & 42 \\
\hline Fife & 57 & 57 \\
\hline Orkney Islands & 93 & 95 \\
\hline $\begin{array}{l}\text { The International HapMap } 3 \text { Consortium } \\
\text { Illumina Human } 1 \mathrm{M} \text { chip }\end{array}$ & NA & 91 \\
\hline Yoruba & NA & 91 \\
\hline $\begin{array}{l}\text { Li et al. } 2008 \\
\text { Illumina HumanHap } 650 \mathrm{~K}\end{array}$ & 125 & NA \\
\hline France & 47 & NA \\
\hline Bergamo Italy & 13 & NA \\
\hline Sardinia Italy & 21 & NA \\
\hline Tuscany Italy & 8 & NA \\
\hline Russia & 25 & NA \\
\hline Adygei Russia & 11 & NA \\
\hline $\begin{array}{l}\text { Yunusbayev et al. } 2012 \\
\text { Illumina } 610 \text { K SNP array }\end{array}$ & 33 & NA \\
\hline Bulgaria & 13 & NA \\
\hline Ukraine & 20 & NA \\
\hline
\end{tabular}




\begin{tabular}{lcc} 
Kovacavic et al. 2014 & \multicolumn{2}{c}{ NA } \\
Illumina 660 K SNP array & 14 & NA \\
Macedonia & 9 & NA \\
Kosovo & 14 & NA \\
Montenegro & 15 & NA \\
Mordovia & 15 & NA \\
Bosnia-Herzegovina (Bosnian) & 18 & NA \\
Serbia/Bosnia-Herzegovina (Serbian) & 83 & NA \\
Yunusbayev et al. 2015 & & \\
IIlumina 650 K/610K/550K SNP array & 13 & NA \\
Germany & 15 & NA \\
Karelia & 12 & NA \\
Gagauz & 32 & NA \\
Russia & 11 & NA \\
Veps & & \\
The 1000 Genomes Project Consortium & $\mathbf{2 7 8}$ & NA \\
IIlumina Omni2.5 array & & NA \\
Tuscan Italy & 98 & NA \\
Finland & 83 & NA \\
Spain & 97 & \\
\hline
\end{tabular}


Table S8. Ancient individuals from the British Isles dating from the Neolithic to the Anglo-Saxon period.

\begin{tabular}{|c|c|c|c|c|c|c|c|c|}
\hline Time period & ${ }^{14} \mathrm{C}$ cal & Lab ID & Sample ID & Country or region & Site & $\begin{array}{r}\text { EuroSNPs } \\
{[\%] \dagger}\end{array}$ & $\begin{array}{r}\text { NEurSNP } \\
{[\%] \ddagger}\end{array}$ & Study \\
\hline $\begin{array}{l}\text { Middle to Late } \\
\text { Neolithic }\end{array}$ & $3343-3020 \mathrm{BC}$ & BA64* & Ballynahatty & Ireland & Ballynahatty & 95.69 & NA & $\begin{array}{l}\text { Cassidy et al. } \\
(2015)\end{array}$ \\
\hline \multirow[t]{3}{*}{ Early Bronze Age } & 2026-1885 BC & RM127 & Rathlin1 & Ireland & $\begin{array}{l}\text { Glebe, Rathlin } \\
\text { Island }\end{array}$ & 95.67 & 99.92 & $\begin{array}{l}\text { Cassidy et al. } \\
(2015)\end{array}$ \\
\hline & 2024-1741 BC & RSK1 & Rathlin2 & Ireland & $\begin{array}{l}\text { Glebe, Rathlin } \\
\text { Island }\end{array}$ & 73.87 & 77.07 & $\begin{array}{l}\text { Cassidy et al. } \\
\text { (2015) }\end{array}$ \\
\hline & $1736-1534 \mathrm{BC}$ & RSK2 & Rathlin3 & Ireland & $\begin{array}{l}\text { Glebe, Rathlin } \\
\text { Island }\end{array}$ & 53.31 & 55.58 & $\begin{array}{l}\text { Cassidy et al. } \\
\text { (2015) }\end{array}$ \\
\hline \multirow[t]{3}{*}{ Late Iron Age } & $210 \mathrm{BC}-40 \mathrm{AD}$ & 1489 & M1489 & Northern Britain & Melton & 37.25 & 38.92 & $\begin{array}{l}\text { Martiniano et al. } \\
\text { (2016) }\end{array}$ \\
\hline & $160 \mathrm{BC}-50 \mathrm{AD}$ & SK1964 & HI1 & East England & Hinxton & 18.99 & 19.67 & $\begin{array}{l}\text { Schiffels et al. } \\
\text { (2016) }\end{array}$ \\
\hline & $170 \mathrm{BC}-80 \mathrm{AD}$ & SK1231 & $\mathrm{H} 12$ & East England & Hinxton & 80.18 & 83.3 & $\begin{array}{l}\text { Schiffels et al. } \\
\text { (2016) }\end{array}$ \\
\hline Roman & 71-400 AD & $\begin{array}{l}\text { 3DT16, 3DT26*, } \\
\text { 6DT3, 6DT18, } \\
\text { 6DT21, 6DT22, } \\
\text { 6DT23 }\end{array}$ & $\begin{array}{l}\text { 3DRIF-16, 3DRIF- } \\
\text { 26, 6DRIF-3, 6DRIF- } \\
\text { 18, 6DRIF-21, } \\
\text { 6DRIF-22, 6DRIF-23 }\end{array}$ & Northern Britain & Driffield Terrace & $\begin{array}{r}48.15,64.63 \\
78.82,64.22 \\
67.04,65.71 \\
47.39\end{array}$ & $\begin{array}{r}50,15, N A \\
82,29,67.14, \\
69.9,68,66 \\
49.32\end{array}$ & $\begin{array}{l}\text { Martiniano et al. } \\
\text { (2016) }\end{array}$ \\
\hline \multirow[t]{4}{*}{ Anglo-Saxon } & $550-650$ AD & NO3423 & NO3423 & Northern Britain & Norton on Tees & 63.39 & 66.3 & \multirow{4}{*}{$\begin{array}{l}\text { Martiniano et al. } \\
\text { (2016) } \\
\text { Schiffels et al. } \\
\text { (2016) } \\
\text { Schiffels et al. } \\
\text { (2016) } \\
\text { Schiffels et al. } \\
\text { (2016) }\end{array}$} \\
\hline & 631-776 AD & SK5518 & HS2 & East England & Hinxton & 42.28 & 43.61 & \\
\hline & $666-770$ AD & SK241 & HS1 & East England & Hinxton & 37.98 & 39.05 & \\
\hline & $690-881$ AD & SK355 & HS3 & East England & Hinxton & 11.52 & 11.88 & \\
\hline
\end{tabular}

Samples marked with an asterisk symbol (*) are not of North European ancestry (Fig. S8A) and were therefore excluded from further analysis. $†$ Overlapping

SNPs with European reference data. + Overlapping SNPs with North European reference data. 
Table S9. D-statistics of the form D(Yoruba, X; Norse, Celtic). These results are plotted in main Fig. 2B. The table is sorted by D-statistic value, from lowest to highest.

\begin{tabular}{|c|c|c|c|c|c|c|c|c|c|}
\hline Outgroup & Sample (X) & Pop1 & Pop2 & D-stat & SD & $Z$ & BABA & ABBA & No. of SNPs \\
\hline Yoruba & DAV-A8 & Norse & Celtic & -0.0023 & 0.00031 & -7.432 & 27702 & 27830 & 379483 \\
\hline Yoruba & SVK-A1 & Norse & Celtic & -0.0023 & 0.00033 & -6.917 & 18768 & 18854 & 256472 \\
\hline Yoruba & DAV-A9 & Norse & Celtic & -0.0016 & 0.000392 & -4.14 & 6617 & 6639 & 91550 \\
\hline Yoruba & NNM-A1 & Norse & Celtic & -0.0016 & 0.000427 & -3.705 & 6886 & 6908 & 94136 \\
\hline Yoruba & DKS-A1 & Norse & Celtic & -0.0013 & 0.000386 & -3.381 & 8760 & 8783 & 119576 \\
\hline Yoruba & SSJ-A2 & Norse & Celtic & -0.0011 & 0.000489 & -2.302 & 4335 & 4344 & 59687 \\
\hline Yoruba & TGS-A1 & Norse & Celtic & -0.0011 & 0.000348 & -3.16 & 16785 & 16822 & 230869 \\
\hline Yoruba & VDP-A5 & Norse & Celtic & -0.001 & 0.000335 & -3.044 & 25834 & 25887 & 351726 \\
\hline Yoruba & FOV-A1 & Norse & Celtic & -0.0009 & 0.000376 & -2.339 & 11451 & 11472 & 157205 \\
\hline Yoruba & VDP-A6 & Norse & Celtic & -0.0009 & 0.00035 & -2.451 & 19521 & 19554 & 266003 \\
\hline Yoruba & MKR-A1 & Norse & Celtic & -0.0007 & 0.000538 & -1.374 & 3470 & 3475 & 47201 \\
\hline Yoruba & KOV-A2 & Norse & Celtic & -0.0003 & 0.000371 & -0.814 & 10378 & 10384 & 143139 \\
\hline Yoruba & HSJ-A1 & Norse & Celtic & -0.0002 & 0.000332 & -0.602 & 29920 & 29932 & 404010 \\
\hline Yoruba & FSS-A1 & Norse & Celtic & 0.0001 & 0.000337 & 0.44 & 17253 & 17247 & 236555 \\
\hline Yoruba & VDP-A7 & Norse & Celtic & 0.0003 & 0.000318 & 0.849 & 25736 & 25722 & 350236 \\
\hline Yoruba & GRS-A1 & Norse & Celtic & 0.0004 & 0.000389 & 0.918 & 8531 & 8525 & 117195 \\
\hline Yoruba & GTE-A1 & Norse & Celtic & 0.0005 & 0.000499 & 0.915 & 3904 & 3900 & 53242 \\
\hline Yoruba & PSK-A26 & Norse & Celtic & 0.0005 & 0.000354 & 1.393 & 13600 & 13586 & 187705 \\
\hline Yoruba & SSG-A3 & Norse & Celtic & 0.0008 & 0.000572 & 1.33 & 2511 & 2507 & 34574 \\
\hline Yoruba & YGS-B2 & Norse & Celtic & 0.001 & 0.000463 & 2.248 & 4558 & 4549 & 63332 \\
\hline Yoruba & SBT-A1 & Norse & Celtic & 0.0011 & 0.000299 & 3.531 & 29254 & 29192 & 397830 \\
\hline Yoruba & STT-A2 & Norse & Celtic & 0.0014 & 0.000314 & 4.468 & 29866 & 29783 & 403679 \\
\hline Yoruba & NPR-A2 & Norse & Celtic & 0.0017 & 0.00039 & 4.324 & 9563 & 9531 & 133068 \\
\hline Yoruba & ORE-A1 & Norse & Celtic & 0.0018 & 0.000414 & 4.422 & 7046 & 7020 & 96146 \\
\hline Yoruba & SSG-A2 & Norse & Celtic & 0.0018 & 0.00031 & 5.787 & 29770 & 29663 & 403271 \\
\hline Yoruba & KNS-A1 & Norse & Celtic & 0.0025 & 0.000374 & 6.591 & 11131 & 11076 & 152735 \\
\hline Yoruba & SSG-A4 & Norse & Celtic & 0.0026 & 0.000315 & 8.251 & 29470 & 29317 & 400347 \\
\hline
\end{tabular}


Table S10. Haplogroup assignments of North European reference individuals.

\begin{tabular}{|c|c|c|c|c|c|c|c|c|c|c|}
\hline $\begin{array}{l}\text { chrY } \\
\text { haplogroup }\end{array}$ & $\begin{array}{l}\text { Iceland } \\
\text { CNT (\%) }\end{array}$ & $\begin{array}{l}\text { Norway } \\
\text { CNT (\%) }\end{array}$ & $\begin{array}{l}\text { Sweden } \\
\text { CNT (\%) }\end{array}$ & $\begin{array}{l}\text { Denmark } \\
\text { CNT (\%) }\end{array}$ & $\begin{array}{l}\text { Ireland CNT } \\
(\%)\end{array}$ & $\begin{array}{l}\text { Scotland } \\
\text { CNT (\%) }\end{array}$ & $\begin{array}{l}\text { Wales CNT } \\
(\%)\end{array}$ & $\begin{array}{l}\text { England } \\
\text { CNT (\%) }\end{array}$ & $\begin{array}{l}\text { Norse CNT } \\
(\%)\end{array}$ & $\begin{array}{l}\text { Celtic CNT } \\
(\%)\end{array}$ \\
\hline R1b1 & $154(33.41)$ & 74 (30.2) & $48(19.92)$ & $236(39.14)$ & 112 (81.75) & $48(52.17)$ & $48(81.36)$ & $261(61.27)$ & $122(25.10)$ & $197(72.43)$ \\
\hline R1a1 & $113(24.51)$ & $61(24.9)$ & 46 (19.09) & $62(10.28)$ & $2(1.46)$ & $7(7.61)$ & 2 (3.39) & $14(3.29)$ & 107 (22.02) & $6(2.21)$ \\
\hline 11 & $139(30.15)$ & $80(32.65)$ & $99(41.08)$ & $192(31.84)$ & 0 & $5(5.43)$ & 2 (3.39) & 37 (8.69) & $179(36.83)$ & $8(2.94)$ \\
\hline I1a1 & 0 & 0 & 0 & 0 & 0 & $2(2.17)$ & 0 & $18(4.23)$ & 0 & $2(0.74)$ \\
\hline 12 & 0 & $2(0.82)$ & $2(0.83)$ & $6(1.0)$ & 0 & $1(1.09)$ & 0 & $7(1.64)$ & $4(0.82)$ & $1(0.37)$ \\
\hline $12 \mathrm{a}$ & 0 & 0 & 0 & 0 & $8(5.84)$ & 0 & 0 & 0 & 0 & $8(2.94)$ \\
\hline $12 \mathrm{a} 1$ & $6(1.3)$ & 0 & $1(0.41)$ & 0 & 0 & 0 & 0 & $2(0.47)$ & 0 & 0 \\
\hline $12 \mathrm{a} 2$ & $12(2.6)$ & $14(5.71)$ & $6(2.49)$ & $45(7.46)$ & $8(5.84)$ & $3(3.26)$ & 2 (3.39) & $29(6.81)$ & $20(4.12)$ & $13(4.78)$ \\
\hline Q & 0 & 0 & 0 & $1(0.17)$ & $1(0.73)$ & 0 & 0 & 0 & 0 & 0 \\
\hline Q1a2 & $32(6.94)$ & $3(1.22)$ & 8 (3.32) & $8(1.33)$ & 0 & 0 & $1(1.69)$ & $1(0.23)$ & $11(2.26)$ & $1(0.37)$ \\
\hline $\mathrm{E}$ & 0 & 0 & 0 & 0 & 0 & $1(1.09)$ & 0 & $3(0.70)$ & 0 & $1(0.37)$ \\
\hline E1b1 & $2(0.43)$ & 0 & $4(1.66)$ & 12 (1.99) & $1(0.73)$ & $23(25.0)$ & 2 (3.39) & $32(7.51)$ & $4(0.82)$ & $26(9.56)$ \\
\hline E2b1 & 0 & 0 & 0 & 0 & 0 & 0 & 0 & $2(0.47)$ & 0 & 0 \\
\hline $\mathrm{J}$ & 0 & 0 & 0 & $4(0.66)$ & 0 & 0 & 0 & $2(0.47)$ & 0 & 0 \\
\hline J2 & 0 & 0 & 0 & 0 & 0 & $1(1.09)$ & $1(1.69)$ & 0 & 0 & $2(0.74)$ \\
\hline J2a1 & $1(0.22)$ & $1(0.41)$ & $1(0.41)$ & $6(1.0)$ & 0 & 0 & 0 & $4(0.94)$ & $2(0.41)$ & 0 \\
\hline $\mathrm{J} 2 \mathrm{~b} 2$ & 0 & $1(0.41)$ & $1(0.41)$ & $1(0.17)$ & 0 & 0 & 0 & $4(0.94)$ & $2(0.41)$ & 0 \\
\hline G & 0 & 0 & 0 & 0 & $1(0.73)$ & 0 & 0 & 0 & 0 & $1(0.37)$ \\
\hline G2 & 0 & 0 & $1(0.41)$ & $1(0.17)$ & $1(0.73)$ & 0 & 0 & 0 & $1(0.21)$ & $1(0.37)$ \\
\hline G2a2 & 0 & $1(0.41)$ & $3(1.24)$ & $10(1.66)$ & $3(2.19)$ & $1(1.09)$ & $1(1.69)$ & $7(1.64)$ & $4(0.82)$ & $5(1.84)$ \\
\hline $\mathrm{T}$ & 0 & $1(0.41)$ & $1(0.41)$ & 0 & 0 & 0 & 0 & $1(0.23)$ & $2(0.41)$ & 0 \\
\hline T1a2 & 0 & 0 & 0 & $2(0.33)$ & 0 & 0 & 0 & 0 & 0 & 0 \\
\hline $\mathrm{DE}$ & 0 & $1(0.41)$ & 0 & 0 & 0 & 0 & 0 & 0 & $1(0.21)$ & 0 \\
\hline $\mathrm{H} 1$ & 0 & 0 & 0 & 0 & 0 & 0 & 0 & $1(0.23)$ & 0 & 0 \\
\hline L1 & 0 & 0 & 0 & $1(0.17)$ & 0 & 0 & 0 & 0 & 0 & 0 \\
\hline N1c1 & $2(0.43)$ & $6(2.45)$ & $21(8.71)$ & $16(2.65)$ & 0 & 0 & 0 & $1(0.23)$ & $27(5.56)$ & 0 \\
\hline
\end{tabular}


Table S11. D-statistics of the form D(Yoruba, X; Norse, Icelandic) and D(Yoruba, X; Celtic, Icelandic). These results are plotted in main Fig. $3 \mathrm{~B}$. The table is sorted by $\mathrm{D}$-statistic value, from lowest to highest.

\begin{tabular}{|c|c|c|c|c|c|c|c|c|c|}
\hline Outgroup & Sample (X) & Pop1 & Pop2 & D-stat & SD & Z & BABA & ABBA & No. of SNPs \\
\hline Yoruba & DKS-A1 & Norse & Iceland & 0.0002 & 0.000352 & 0.616 & 8766 & 8762 & 119576 \\
\hline Yoruba & SK355 & Norse & Iceland & 0.0002 & 0.000513 & 0.45 & 3241 & 3240 & 48003 \\
\hline Yoruba & DAV-A8 & Norse & Iceland & 0.0003 & 0.000313 & 1.088 & 27755 & 27736 & 379483 \\
\hline Yoruba & SSJ-A2 & Norse & Iceland & 0.0003 & 0.00046 & 0.656 & 4338 & 4336 & 59687 \\
\hline Yoruba & NO3423 & Norse & Iceland & 0.0005 & 0.000307 & 1.557 & 19523 & 19504 & 267891 \\
\hline Yoruba & PSK-A26 & Norse & Iceland & 0.0005 & 0.000342 & 1.382 & 13583 & 13571 & 187705 \\
\hline Yoruba & 6DT21 & Norse & Iceland & 0.0006 & 0.000311 & 1.901 & 20597 & 20572 & 282442 \\
\hline Yoruba & 6DT3 & Norse & Iceland & 0.0007 & 0.000313 & 2.271 & 24316 & 24282 & 332500 \\
\hline Yoruba & MKR-A1 & Norse & Iceland & 0.0007 & 0.000485 & 1.446 & 3471 & 3467 & 47201 \\
\hline Yoruba & HSJ-A1 & Norse & Iceland & 0.0008 & 0.000325 & 2.538 & 29922 & 29872 & 404010 \\
\hline Yoruba & NPR-A2 & Norse & Iceland & 0.0008 & 0.000367 & 2.251 & 9543 & 9528 & 133068 \\
\hline Yoruba & SBT-A1 & Norse & Iceland & 0.0008 & 0.000306 & 2.683 & 29213 & 29165 & 397830 \\
\hline Yoruba & SK241 & Norse & Iceland & 0.0008 & 0.000359 & 2.239 & 10832 & 10814 & 157768 \\
\hline Yoruba & SK5518 & Norse & Iceland & 0.0008 & 0.000341 & 2.199 & 12098 & 12079 & 176220 \\
\hline Yoruba & SSG-A3 & Norse & Iceland & 0.0008 & 0.000558 & 1.479 & 2509 & 2505 & 34574 \\
\hline Yoruba & GRS-A1 & Norse & Iceland & 0.0009 & 0.000364 & 2.465 & 8528 & 8513 & 117195 \\
\hline Yoruba & STT-A2 & Norse & Iceland & 0.0009 & 0.000303 & 3.066 & 29816 & 29760 & 403679 \\
\hline Yoruba & 3DT16 & Norse & Iceland & 0.001 & 0.000343 & 2.974 & 14727 & 14697 & 202621 \\
\hline Yoruba & FSS-A1 & Norse & Iceland & 0.001 & 0.000323 & 3.17 & 17250 & 17215 & 236555 \\
\hline Yoruba & VDP-A7 & Norse & Iceland & 0.001 & 0.000315 & 3.111 & 19538 & 19499 & 266003 \\
\hline Yoruba & 1489 & Norse & Iceland & 0.0011 & 0.000371 & 2.967 & 11424 & 11399 & 157374 \\
\hline Yoruba & SVK-A1 & Norse & Iceland & 0.0011 & 0.000322 & 3.315 & 18820 & 18779 & 256472 \\
\hline Yoruba & YGS-B2 & Norse & Iceland & 0.0011 & 0.00044 & 2.516 & 4554 & 4544 & 63332 \\
\hline Yoruba & NNM-A1 & Norse & Iceland & 0.0012 & 0.000406 & 2.857 & 6900 & 6884 & 94136 \\
\hline Yoruba & SK1231 & Norse & Iceland & 0.0012 & 0.000303 & 3.842 & 23823 & 23768 & 336593 \\
\hline Yoruba & TGS-A1 & Norse & Iceland & 0.0012 & 0.000318 & 3.707 & 16808 & 16769 & 230869 \\
\hline Yoruba & 6DT23 & Norse & Iceland & 0.0013 & 0.000331 & 3.976 & 14511 & 14473 & 199299 \\
\hline Yoruba & DAV-A9 & Norse & Iceland & 0.0013 & 0.000403 & 3.29 & 6631 & 6613 & 91550 \\
\hline Yoruba & RSK2 & Norse & Iceland & 0.0013 & 0.000334 & 3.847 & 16305 & 16264 & 224582 \\
\hline Yoruba & GTE-A1 & Norse & Iceland & 0.0014 & 0.000481 & 2.81 & 3902 & 3892 & 53242 \\
\hline Yoruba & KNS-A1 & Norse & Iceland & 0.0014 & 0.000366 & 3.862 & 11104 & 11073 & 152735 \\
\hline
\end{tabular}




\begin{tabular}{|c|c|c|c|c|c|c|c|c|c|}
\hline Yoruba & RM127 & Norse & Iceland & 0.0014 & 0.000302 & 4.679 & 29755 & 29672 & 403724 \\
\hline Yoruba & 6DT18 & Norse & Iceland & 0.0015 & 0.000312 & 4.829 & 19821 & 19762 & 271270 \\
\hline Yoruba & 6DT22 & Norse & Iceland & 0.0015 & 0.000304 & 4.873 & 20204 & 20144 & 277417 \\
\hline Yoruba & RSK1 & Norse & Iceland & 0.0015 & 0.000308 & 4.844 & 22677 & 22610 & 311415 \\
\hline Yoruba & SSG-A2 & Norse & Iceland & 0.0015 & 0.000298 & 5.002 & 29725 & 29637 & 403271 \\
\hline Yoruba & VDP-A5 & Norse & Iceland & 0.0015 & 0.000313 & 4.749 & 25877 & 25800 & 351726 \\
\hline Yoruba & VDP-A6 & Norse & Iceland & 0.0015 & 0.000317 & 4.863 & 25743 & 25664 & 350236 \\
\hline Yoruba & ORE-A1 & Norse & Iceland & 0.0017 & 0.000376 & 4.441 & 7035 & 7011 & 96146 \\
\hline Yoruba & SK1964 & Norse & Iceland & 0.0017 & 0.000429 & 3.897 & 5423 & 5405 & 79495 \\
\hline Yoruba & FOV-A1 & Norse & Iceland & 0.002 & 0.00036 & 5.626 & 11476 & 11429 & 157205 \\
\hline Yoruba & SSG-A4 & Norse & Iceland & 0.002 & 0.000291 & 6.89 & 29415 & 29297 & 400347 \\
\hline Yoruba & KOV-A2 & Norse & Iceland & 0.0028 & 0.000352 & 8.065 & 10403 & 10344 & 143139 \\
\hline Yoruba & 6DT21 & Celtic & Iceland & -0.0011 & 0.000397 & -2.73 & 20567 & 20612 & 282442 \\
\hline Yoruba & KNS-A1 & Celtic & Iceland & -0.001 & 0.000465 & -2.177 & 11082 & 11104 & 152735 \\
\hline Yoruba & 1489 & Celtic & Iceland & -0.0009 & 0.00042 & -2.126 & 11404 & 11424 & 157374 \\
\hline Yoruba & NPR-A2 & Celtic & Iceland & -0.0009 & 0.000462 & -1.907 & 9530 & 9547 & 133068 \\
\hline Yoruba & 6DT23 & Celtic & Iceland & -0.0008 & 0.000397 & -2.082 & 14487 & 14511 & 199299 \\
\hline Yoruba & 6DT22 & Celtic & Iceland & -0.0007 & 0.000376 & -1.848 & 20166 & 20194 & 277417 \\
\hline Yoruba & SK1964 & Celtic & Iceland & -0.0006 & 0.000534 & -1.098 & 5413 & 5420 & 79495 \\
\hline Yoruba & SSG-A4 & Celtic & Iceland & -0.0006 & 0.000374 & -1.538 & 29352 & 29386 & 400347 \\
\hline Yoruba & RSK2 & Celtic & Iceland & -0.0005 & 0.000442 & -1.088 & 16280 & 16296 & 224582 \\
\hline Yoruba & SK1231 & Celtic & Iceland & -0.0005 & 0.000383 & -1.301 & 23790 & 23814 & 336593 \\
\hline Yoruba & STT-A2 & Celtic & Iceland & -0.0005 & 0.000355 & -1.318 & 29783 & 29811 & 403679 \\
\hline Yoruba & 6DT18 & Celtic & Iceland & -0.0004 & 0.000383 & -1.098 & 19790 & 19807 & 271270 \\
\hline Yoruba & RM127 & Celtic & Iceland & -0.0004 & 0.000371 & -1.065 & 29711 & 29734 & 403724 \\
\hline Yoruba & RSK1 & Celtic & Iceland & -0.0003 & 0.000401 & -0.655 & 22646 & 22657 & 311415 \\
\hline Yoruba & SSG-A2 & Celtic & Iceland & -0.0003 & 0.000372 & -0.903 & 29682 & 29702 & 403271 \\
\hline Yoruba & SBT-A1 & Celtic & Iceland & -0.0002 & 0.000365 & -0.494 & 29189 & 29199 & 397830 \\
\hline Yoruba & ORE-A1 & Celtic & Iceland & -0.0001 & 0.000493 & -0.258 & 7026 & 7028 & 96146 \\
\hline Yoruba & PSK-A26 & Celtic & Iceland & -0.0001 & 0.000431 & -0.213 & 13577 & 13580 & 187705 \\
\hline Yoruba & 3DT16 & Celtic & Iceland & 0.0001 & 0.000412 & 0.192 & 14717 & 14715 & 202621 \\
\hline Yoruba & 6DT3 & Celtic & Iceland & 0.0001 & 0.00037 & 0.272 & 24305 & 24300 & 332500 \\
\hline Yoruba & SSG-A3 & Celtic & Iceland & 0.0001 & 0.000664 & 0.148 & 2506 & 2506 & 34574 \\
\hline Yoruba & YGS-B2 & Celtic & Iceland & 0.0001 & 0.000553 & 0.139 & 4549 & 4548 & 63332 \\
\hline Yoruba & SK355 & Celtic & Iceland & 0.0002 & 0.000624 & 0.263 & 3242 & 3241 & 48003 \\
\hline
\end{tabular}




\begin{tabular}{|c|c|c|c|c|c|c|c|c|c|}
\hline Yoruba & SK241 & Celtic & Iceland & 0.0003 & 0.000447 & 0.769 & 10826 & 10819 & 157768 \\
\hline Yoruba & GRS-A1 & Celtic & Iceland & 0.0006 & 0.000468 & 1.203 & 8525 & 8515 & 117195 \\
\hline Yoruba & SK5518 & Celtic & Iceland & 0.0008 & 0.000421 & 1.833 & 12099 & 12080 & 176220 \\
\hline Yoruba & FSS-A1 & Celtic & Iceland & 0.0009 & 0.000414 & 2.22 & 17251 & 17219 & 236555 \\
\hline Yoruba & GTE-A1 & Celtic & Iceland & 0.0009 & 0.000593 & 1.442 & 3902 & 3895 & 53242 \\
\hline Yoruba & HSJ-A1 & Celtic & Iceland & 0.0011 & 0.000389 & 2.71 & 29929 & 29866 & 404010 \\
\hline Yoruba & NO3423 & Celtic & Iceland & 0.0011 & 0.00039 & 2.853 & 19533 & 19489 & 267891 \\
\hline Yoruba & VDP-A7 & Celtic & Iceland & 0.0013 & 0.000401 & 3.142 & 25739 & 25674 & 350236 \\
\hline Yoruba & MKR-A1 & Celtic & Iceland & 0.0014 & 0.0006 & 2.356 & 3473 & 3464 & 47201 \\
\hline Yoruba & DKS-A1 & Celtic & Iceland & 0.0015 & 0.000453 & 3.394 & 8777 & 8750 & 119576 \\
\hline Yoruba & SSJ-A2 & Celtic & Iceland & 0.0015 & 0.0006 & 2.438 & 4342 & 4330 & 59687 \\
\hline Yoruba & VDP-A6 & Celtic & Iceland & 0.0019 & 0.000426 & 4.386 & 19553 & 19480 & 266003 \\
\hline Yoruba & TGS-A1 & Celtic & Iceland & 0.0023 & 0.000421 & 5.397 & 16826 & 16750 & 230869 \\
\hline Yoruba & VDP-A5 & Celtic & Iceland & 0.0025 & 0.000385 & 6.548 & 25903 & 25772 & 351726 \\
\hline Yoruba & DAV-A8 & Celtic & Iceland & 0.0027 & 0.000374 & 7.116 & 27811 & 27664 & 379483 \\
\hline Yoruba & NNM-A1 & Celtic & Iceland & 0.0027 & 0.000487 & 5.537 & 6909 & 6872 & 94136 \\
\hline Yoruba & FOV-A1 & Celtic & Iceland & 0.0029 & 0.000449 & 6.524 & 11484 & 11417 & 157205 \\
\hline Yoruba & DAV-A9 & Celtic & Iceland & 0.003 & 0.000509 & 5.858 & 6641 & 6601 & 91550 \\
\hline Yoruba & KOV-A2 & Celtic & Iceland & 0.0031 & 0.000442 & 7.074 & 10406 & 10341 & 143139 \\
\hline Yoruba & SVK-A1 & Celtic & Iceland & 0.0033 & 0.000402 & 8.324 & 18856 & 18730 & 256472 \\
\hline
\end{tabular}




\section{References:}

33. R. A. Bentley, Strontium isotopes from the earth to the archaeological skeleton: A review. $J$ Archaeol Method Th 13, 135-187 (2006).

34. A. Helgason et al., Sequences from first settlers reveal rapid evolution in Icelandic mtDNA pool. PLoS genetics 5, e1000343 (2009).

35. H. Gestsdóttir, Geldingurinn á Öndverđarnesi. (2000), vol. 1998, pp. 143-150.

36. H. Stefánsson, Enn um silfursalann og urđarbúann. Eimreiđin 4, (1949).

37. B. Gíslason, Beinafundurinn hjá Jökulsá. Lesbók Morgunblađsins 21, 189-195 (1946).

38. Á. Óla, Lesbók Morgunblađsins. (1948).

39. P. M., Skeljastađir, pjórsárdalur. Forntida, Gårdar i Island, (1943).

40. N. Rohland, M. Hofreiter, Ancient DNA extraction from bones and teeth. Nature protocols 2, 1756-1762 (2007).

41. J. Dabney et al., Complete mitochondrial genome sequence of a Middle Pleistocene cave bear reconstructed from ultrashort DNA fragments. Proceedings of the National Academy of Sciences of the United States of America 110, 15758-15763 (2013).

42. M. Meyer, M. Kircher, Illumina sequencing library preparation for highly multiplexed target capture and sequencing. Cold Spring Harbor protocols 2010, pdb prot5448 (2010).

43. S. Lindgreen, AdapterRemoval: easy cleaning of next-generation sequencing reads. BMC Res Notes 5, 337 (2012).

44. H. Li, R. Durbin, Fast and accurate short read alignment with Burrows-Wheeler transform. Bioinformatics 25, 1754-1760 (2009).

45. H. Li et al., The Sequence Alignment/Map format and SAMtools. Bioinformatics 25, 2078-2079 (2009).

46. A. R. Quinlan, I. M. Hall, BEDTools: a flexible suite of utilities for comparing genomic features. Bioinformatics 26, 841-842 (2010).

47. H. Jonsson, A. Ginolhac, M. Schubert, P. L. F. Johnson, L. Orlando, mapDamage2.0: fast approximate Bayesian estimates of ancient DNA damage parameters. Bioinformatics 29, 16821684 (2013).

48. T. S. Korneliussen, A. Albrechtsen, R. Nielsen, ANGSD: Analysis of Next Generation sequencing data. BMC Bioinformatics 15, 356 (2014).

49. L. Orlando et al., Recalibrating Equus evolution using the genome sequence of an early Middle Pleistocene horse. Nature 499, 74-78 (2013).

50. J. Herrero et al., Ensembl comparative genomics resources. Database (Oxford) 2016, (2016).

51. R. M. Andrews et al., Reanalysis and revision of the Cambridge reference sequence for human mitochondrial DNA. Nat Genet 23, 147 (1999).

52. M. Rasmussen et al., An aboriginal Australian genome reveals separate human dispersals into Asia. Science 334, 94-98 (2011).

53. D. H. Alexander, J. Novembre, K. Lange, Fast model-based estimation of ancestry in unrelated individuals. Genome Res 19, 1655-1664 (2009).

54. A. L. Price et al., Long-range LD can confound genome scans in admixed populations. Am J Hum Genet 83, 132-135 (2008).

55. L. Kovacevic et al., Standing at the Gateway to Europe - The Genetic Structure of Western Balkan Populations Based on Autosomal and Haploid Markers. PloS one 9, (2014).

56. J. Z. Li et al., Worldwide human relationships inferred from genome-wide patterns of variation. Science 319, 1100-1104 (2008).

57. B. Yunusbayev et al., The Caucasus as an asymmetric semipermeable barrier to ancient human migrations (vol 29, pg 359, 2012). Molecular Biology and Evolution 29, 1891-1891 (2012).

58. B. Yunusbayev et al., The genetic legacy of the expansion of Turkic-speaking nomads across Eurasia. PLoS genetics 11, 1005068 (2015).

59. D. M. Altshuler et al., A global reference for human genetic variation. Nature 526, 68-74 (2015). 
60. S. Leslie et al., The fine-scale genetic structure of the British population. Nature 519, 309-314 (2015).

61. The Irish DNA Atlas; revealing fine-scale population structure and history within Ireland. Scientific Reports.

62. A. K. Hedstrom et al., Smoking and two human leukocyte antigen genes interact to increase the risk for multiple sclerosis. Brain 134, 653-664 (2011).

63. I. S. o. G. G. (2016). (23 December 2016).

64. N. Patterson, A. L. Price, D. Reich, Population structure and eigenanalysis. PLoS genetics 2, e190 (2006).

65. C. Wang et al., Comparing spatial maps of human population-genetic variation using Procrustes analysis. Stat Appl Genet Mol Biol 9, Article 13 (2010).

66. E. Y. Durand, N. Patterson, D. Reich, M. Slatkin, Testing for ancient admixture between closely related populations. Mol Biol Evol 28, 2239-2252 (2011).

67. R. E. Green et al., A draft sequence of the Neandertal genome. Science 328, 710-722 (2010).

68. D. H. Alexander, K. Lange, Enhancements to the ADMIXTURE algorithm for individual ancestry estimation. BMC Bioinformatics 12, 246 (2011).

69. H. Gestsdóttir, "Kyn- og lífaldursgreiningar á beinum úr íslenskum kumlum". Fornleifastofnun Íslands ; FS055-98151 (Fornleifastofnun Íslands, Reykjavik, 1998). 